\title{
Early and Middle Bajocian (Middle Jurassic) Ammonites from Southern Alaska
}

U.S. GEOLOGICAL SURVEY PROFESSIONAL PAPER 1322
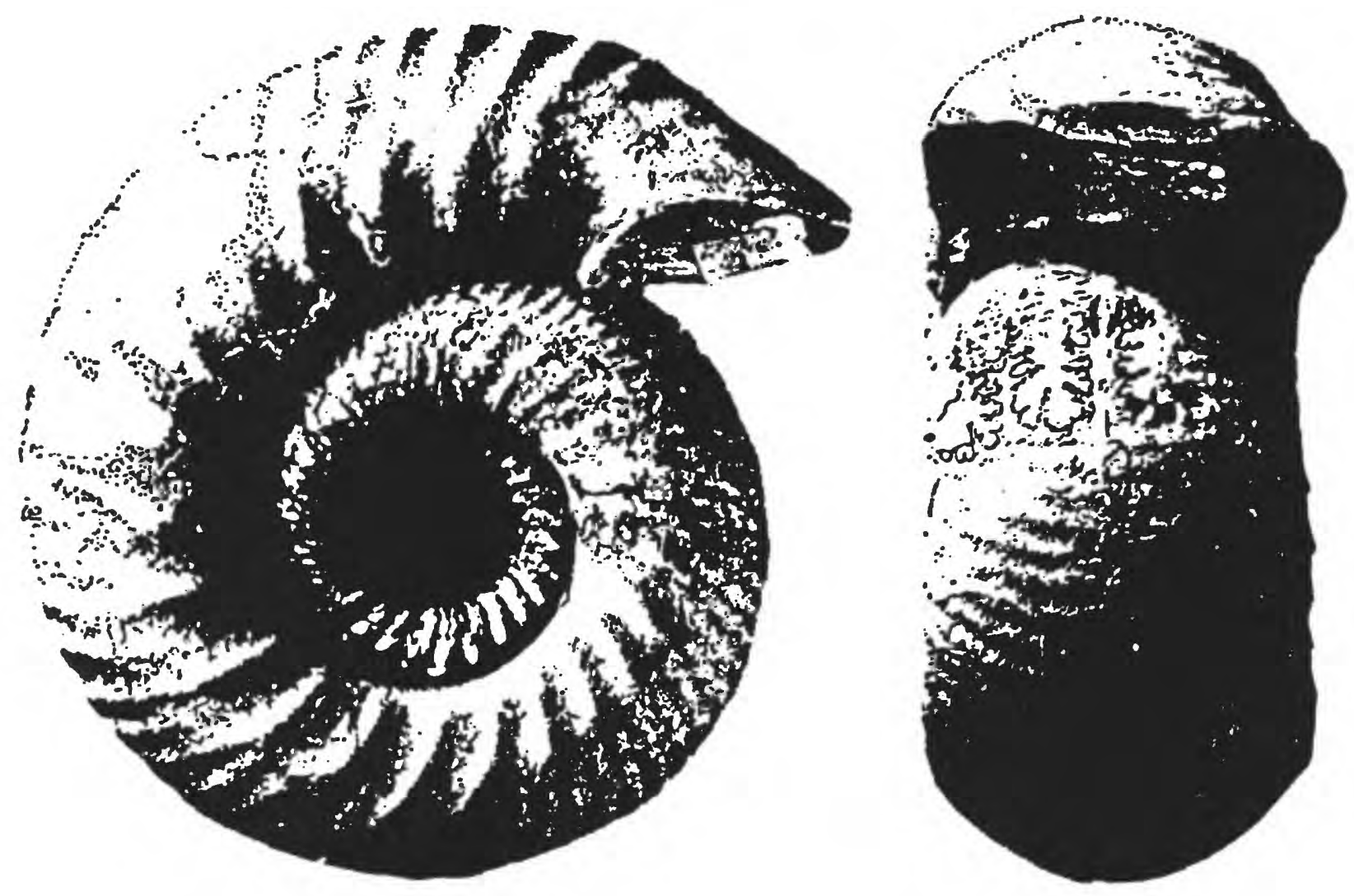


\section{Early and Middle Bajocian (Middle Jurassic) Ammonites from Southern Alaska}

By RALPH W. IMLAY

U.S. GEOLOGICAL SURVEY PROFESSIONAL PAPER 1322

Studies of the early and middle Bajocian ammonites of southern Alaska provide close age determinations and correlations with Europe, Arctic Alaska, Arctic Canada, and the Pacific Coast region in general

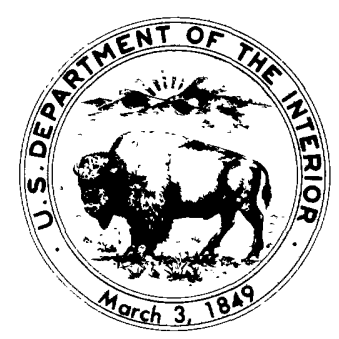




\section{DEPARTMENT OF THE INTERIOR}

WILLIAM P. CLARK, Secretary

\section{U.S. GEOLOGICAL SURVEY}

Dallas L. Peck, Director

\section{Library of Congress Cataloging in Publication Data}

Imlay, Ralph Willard, 1908-

Early and middle Bajocian (Middle Jurassic) ammonites from southern Alaska.

(Geological Survey professional paper; 1322)

Bibliography: p.

Supt. of Docs. no.: I 19.16:1322

1. Ammonoidea. 2. Paleontology-Jurassic. 3. Paleontology-Alaska. I. Title. II. Series. QE807.A5I584 $1984 \quad 564 ' .53 \quad 84-600032$

For sale by the Distribution Branch, U.S. Geological Survey, 604 South Pickett Street, Alexandria, VA 22304 


\section{CONTENTS}

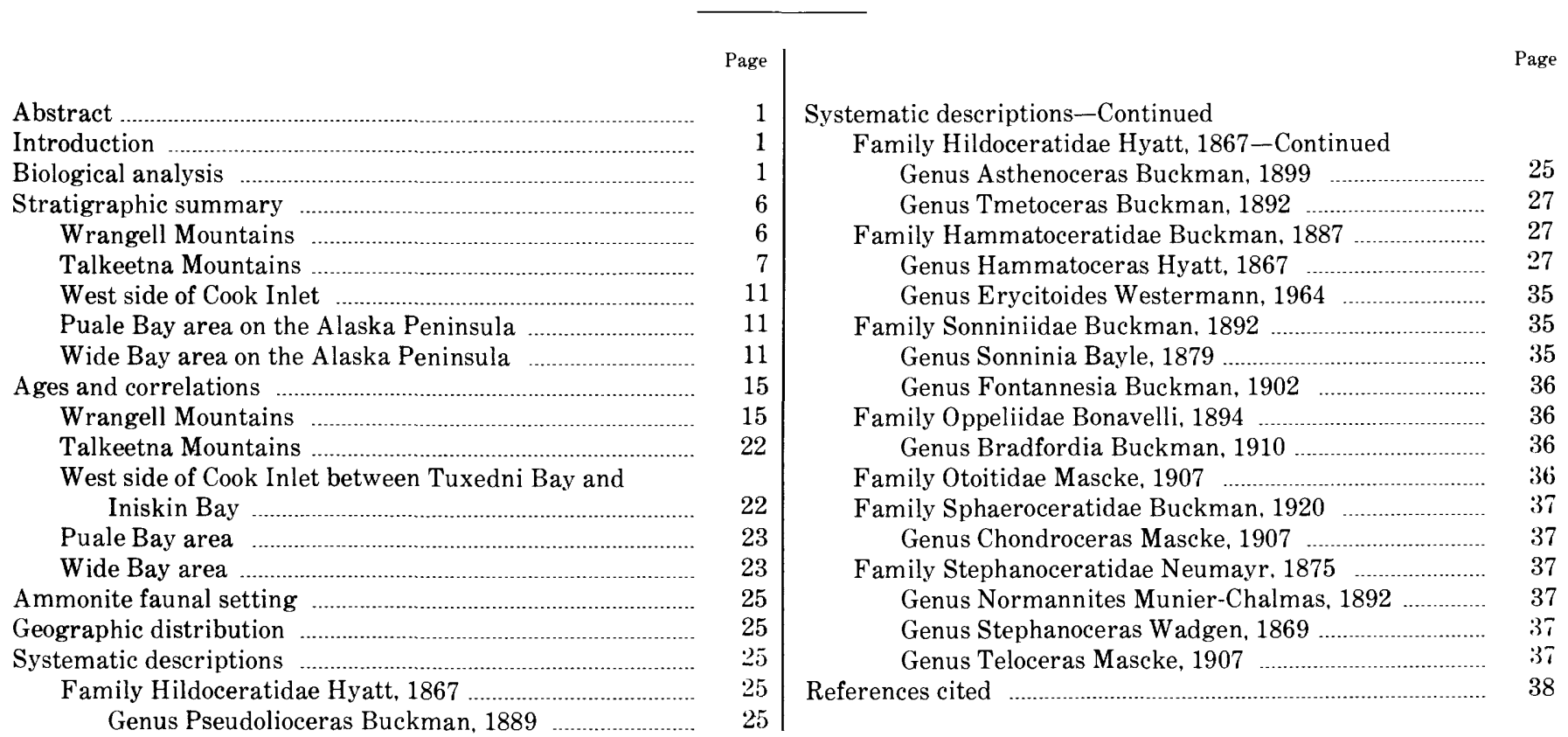

\section{ILLUSTRATIONS}

[Plates are at back of report]

Plate 1. Asthenoceras, Tmetoceras, Hammatoceras, Erycitoides, E. (Kialagvikes), Bradfordia, and Otoites.

2. Pseudolioceras, Sonninia, Fontannesia, Chondroceras, Normannites, Stephanoceras (Skirroceras), and Teloceras.

FIGURE 1. Generalized index map of principal areas of outcrop of Bajocian marine rocks in southern Alaska: (1) Wrangell Mountains; (2) Talkeetna Mountains; (3) peninsula between Tuxedni Bay and Chinitna Bay; (4) Iniskin Peninsula; (5) Puale Bay; and (6) Wide Bay

2-7. Detailed index maps of listed early and middle Bajocian ammonite localities in southern Alaska:

2. In the Wrangell Mountains

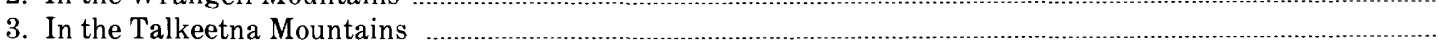

4. West side of Cook Inlet between Tuxedni Bay and Chinitna Bay

5. West of Cook Inlet on the Iniskin Peninsula

6. Northeast of Puale Bay on the Alaska Peninsula

7. At Wide Bay on the Alaska Peninsula

8-15. Diagrams showing:

8. Stratigraphic positions and correlations of Bajocian rocks in southern Alaska

9. Stratigraphic positions of some Bajocian ammonite localities west of Cook Inlet between Tuxedni Bay and Iniskin Bay

10. Stratigraphic positions of some Bajocian ammonite localities on the northeast side of Puale Bay on the Alaska Peninsula 
14. Stratigraphic and chronologic correlations of some early and middle Bajocian ammonites present near Wide Bay on the Alaska Peninsula

15. Correlations and comparisons of Bajocian ammonite faunas in southern Alaska

\section{TABLES}

TABLE 1. Early and middle Bajocian (Middle Jurassic) ammonite genera and subgenera in southern Alaska showing biological relationships and relative numbers available for study

2. Geographic distribution of early and middle Bajocian ammonites in the Wrangell and Talkeetna Mountains .....

3. Geographic distribution of early and middle Bajocian ammonites west of Cook Inlet and northeast of Puale Bay on the Alaska Peninsula

4. Geographic distribution of early and middle Bajocian ammonites near Wide Bay on the Alaska Peninsula

5. Descriptions of middle and lower Bajocian fossil localities in southern Alaska 


\title{
EARLY AND MIDDLE BAJOCIAN (MIDDLE JURASSIC) AMMONITES FROM SOUTHERN ALASKA
}

\author{
By RALPH W. IMLAY
}

\begin{abstract}
Early and middle Bajocian (Middle Jurassic) ammonites have been found in six areas in southern Alaska over a distance of about $500 \mathrm{mi}(800 \mathrm{~km})$ from the Wrangell Mountains on the east to the Wide Bay area of the Alaska Peninsula on the west. In the Wrangell Mountains. some float obtained near the base of the Nizina Mountain Formation has furnished the ammonites Chondroceras. Normanuites, and Teloceras, which constitute good evidence for a late middle Bajocian age not older than the upper part of the Stephanoceras humphriesianum zone.

In the Nelchina area of the Talkeetna Mountains northeast of Anchorage, the Tuxedni Group has furnished ammonites ranging in age from latest early Bajocian to early late Bajocian. These ammonites from the base upward include (1) Erycitoides howelli (White), representing the Graphoceras concarum zone; (2) Somninia (Euhoploceras) bifurcata Westermann, representing the lower part of the Som minia somerbyi zone; (3) Parabigotites crassicostatus Imlay. Bradfordia costidensa Imlay, and Otoites, representing the Otoites sanzei zone; (4) Normannites rariabilis Imlay, Stemmatoceras, Leptosphinctess, and Chomdroceras, representing the Stephanoceras humphriesianum zone; and (5) Megasphaeroceras. Sphatoceras, Cadomites, and Normamites, representing the topmost Strenoceras subfurcutam zone of early late Bajocian age.

An even more complete ammonite succession of early to middle Bajocian age has been found on the west side of Cook Inlet between Tuxedni Bay and the eastern part of the Iniskin Peninsula just west of Chinitna Bay. Basally that succession differs from the succession in the Talkeetna Mountains by the presence of Tmetoceras scissum (Benecke) both below and along with occurrences of Erycitoides homelli (White) and by the presence of Emileia, Somminia, and $S$. (Papilliceras) between the underlying beds containing Parabigotites and the overlying beds containing Teloceras. Normannites, and Choudroceras. The presence of Tmetoceras below the occurrences of Erycitoide's favors an age slightly older than the Graphoceras con'arum zone of latest early Bajocian age. The presence of Somninia and Emileic is evidence of an age not younger than the zone of Otoites salizei.

The Bajocian ammonite succession at Wide Bay is essentially the same as that on the west side of Cook Inlet as high as the bed containing Sonninia triedniensis. Imlay. The succession at Wide Bay, however, has furnished more genera and species and has made possible a threefold faunule division of the beds characterized by Docidoceras (Pseudocidoceras) widebayense.
\end{abstract}

\section{INTRODUCTION}

Most of the early and middle Bajocian (Middle Jurassic) ammonite taxa present in southern Alaska were described by the writer in 1964 and by Gerd Westerman in 1964 and 1969 (figs. 1-7). 'The writer at that time dealt mainly with ammonites collected either northwest of Cook Inlet between Tuxedni Bay and Iniskin Bay or in the eastern part of the Nelchina area of the Talkeetna Mountains. Gerd Westermann at those times dealt mainly with ammonites of late early to early middle Bajocian age that had been collected near Wide Bay on the Alaska Peninsula. Most of those collections had been made by field geologists working for the U.S. Geological Survey, as listed by Imlay (1964, p. B1), who also made extensive collections from Bajocian sedimentary rocks in southern Alaska, in 1948, 1952, 1962, 1972, 1974, and 1977.

The stratigraphic occurrences of the ammonites (figs. 8-13) are based mainly on studies by R. L. Detterman (1963) and by J. K. Hartsock (1966, p. 20-34) in the area west of Cook Inlet; by Arthur Grantz (1965) in the Nelchina area of the Talkeetna Mountains; by E. M. MacKevett, Jr. (1971, p. 16, 17), in the Wrangell Mountains; and by R. L. Detterman and associates (1977, 1980, and 1981) in the Paule Bay and Wide Bay areas of the Alaska Peninsula.

Only those taxa are described herein that have not previously been identified or described, or for which new biologic, stratigraphic, or geographic data are now available.

\section{BIOLOGICAL ANALYSIS}

The U.S. Geological Survey's fossil collections from southern Alaska contain at least 1,224 ammonite specimens of early and middle Bajocian age. Their distribution by genus, subgenus, subfamily, and family is shown in table 1. Among the families, the Hammatoceratidae comprise about $281 / 2$ percent of the total number of specimens; the Stephaneroceratidae, nearly 19 percent; the Sonniniidae, $81 / 2$ percent; the Sphaeroceratidae and Perisphinctidae, each a little more than 8 percent; the Oppeliidae, $7 \frac{1}{2}$ percent; the Otoitidae, $6 \frac{1}{2}$ percent; the Phylloceratidae and Hildoceratidae, each 


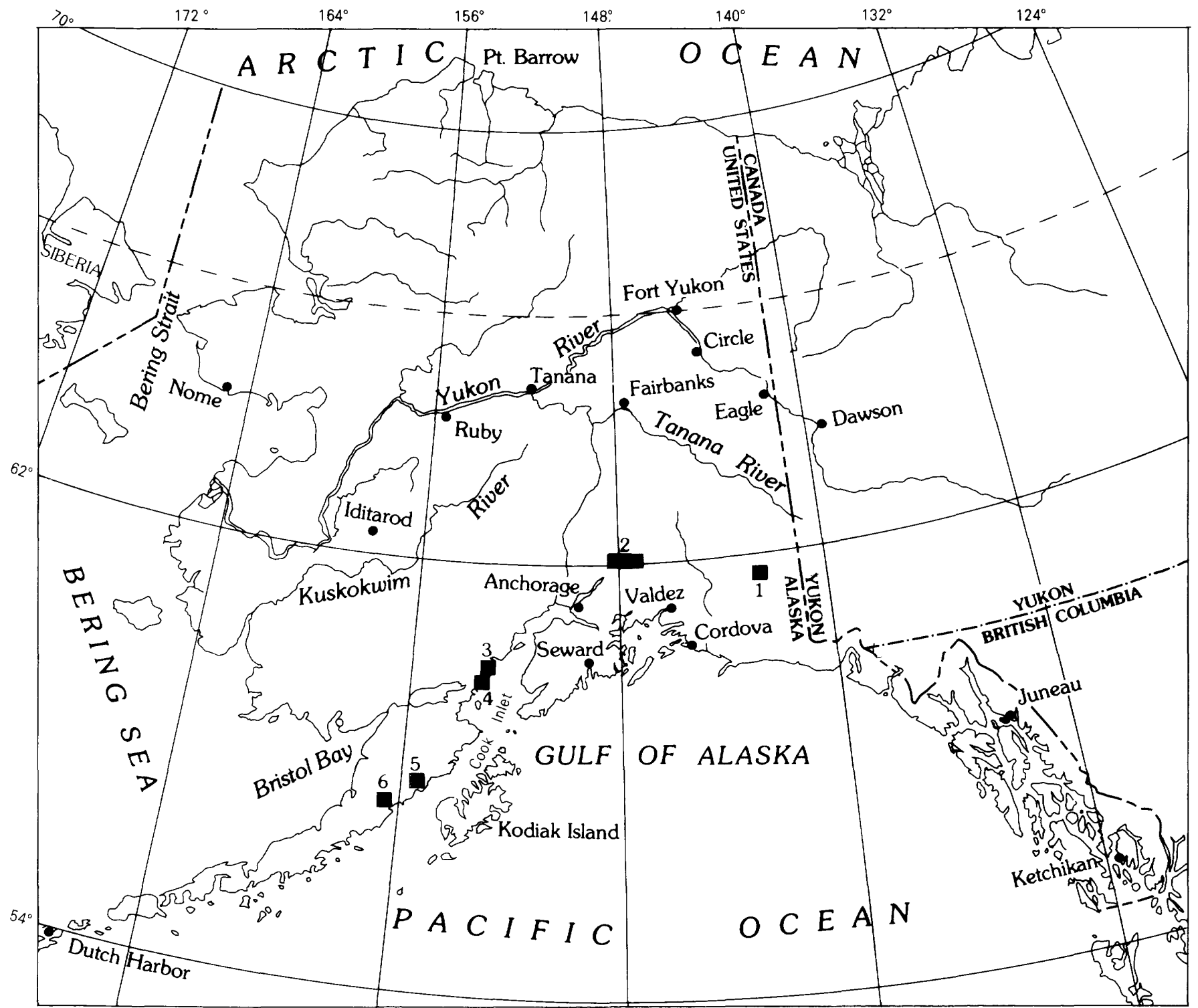

FIGURE 1.-Principal areas of outcrop of Bajocian marine rocks in southern Alaska: (1) Wrangell Mountains; (2) Talkeetna Mountains; (3) Peninsula between Tuxedni Bay and Chinitna Bay; (4) Iniskin Peninsula; (5) Puale Bay; and (6) Wide Bay. 


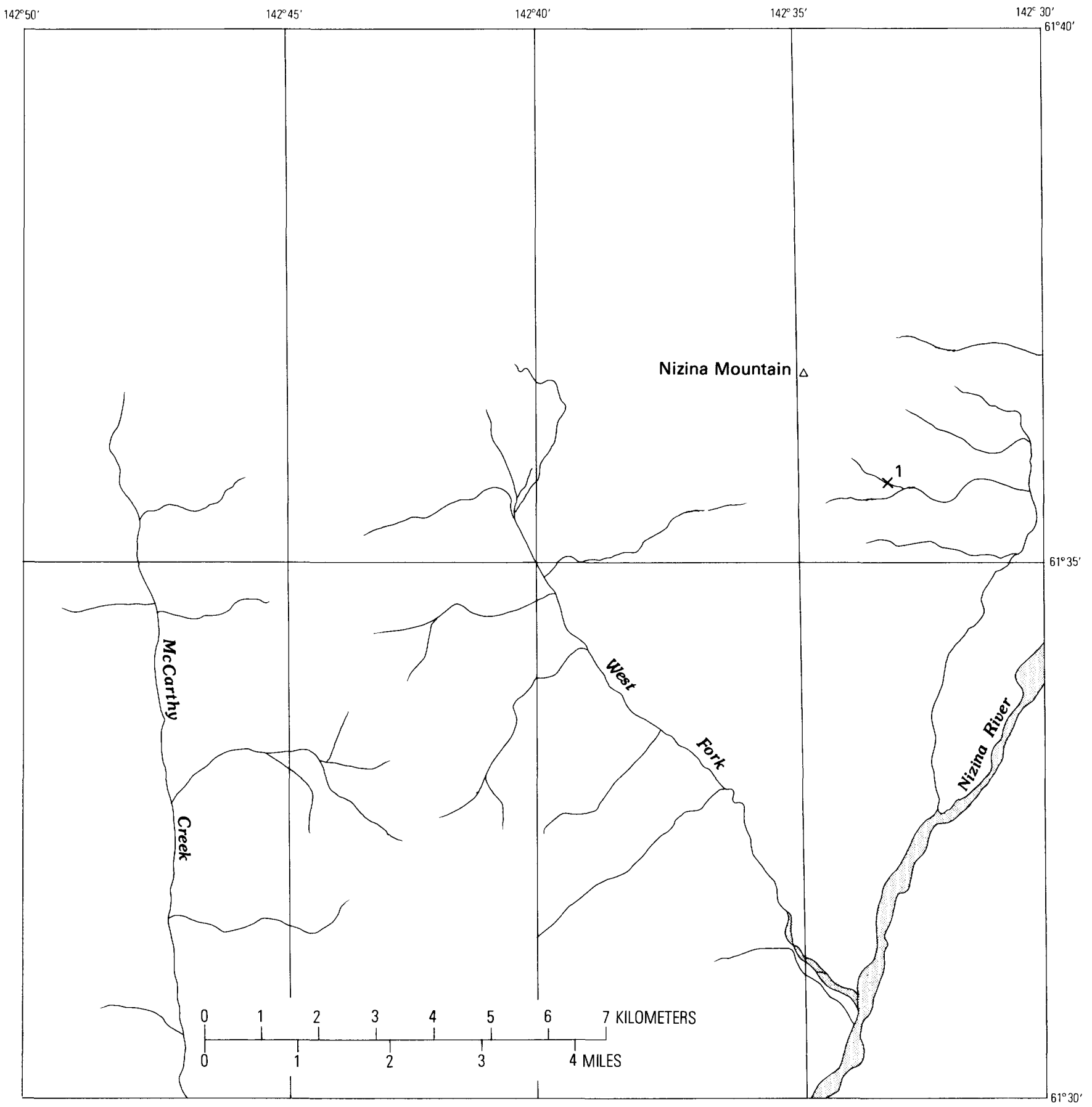

FIGURE 2.-Listed early and middle Bajocian ammonite locality in the Wrangell Mountains. Number refers to that given in table 5. 


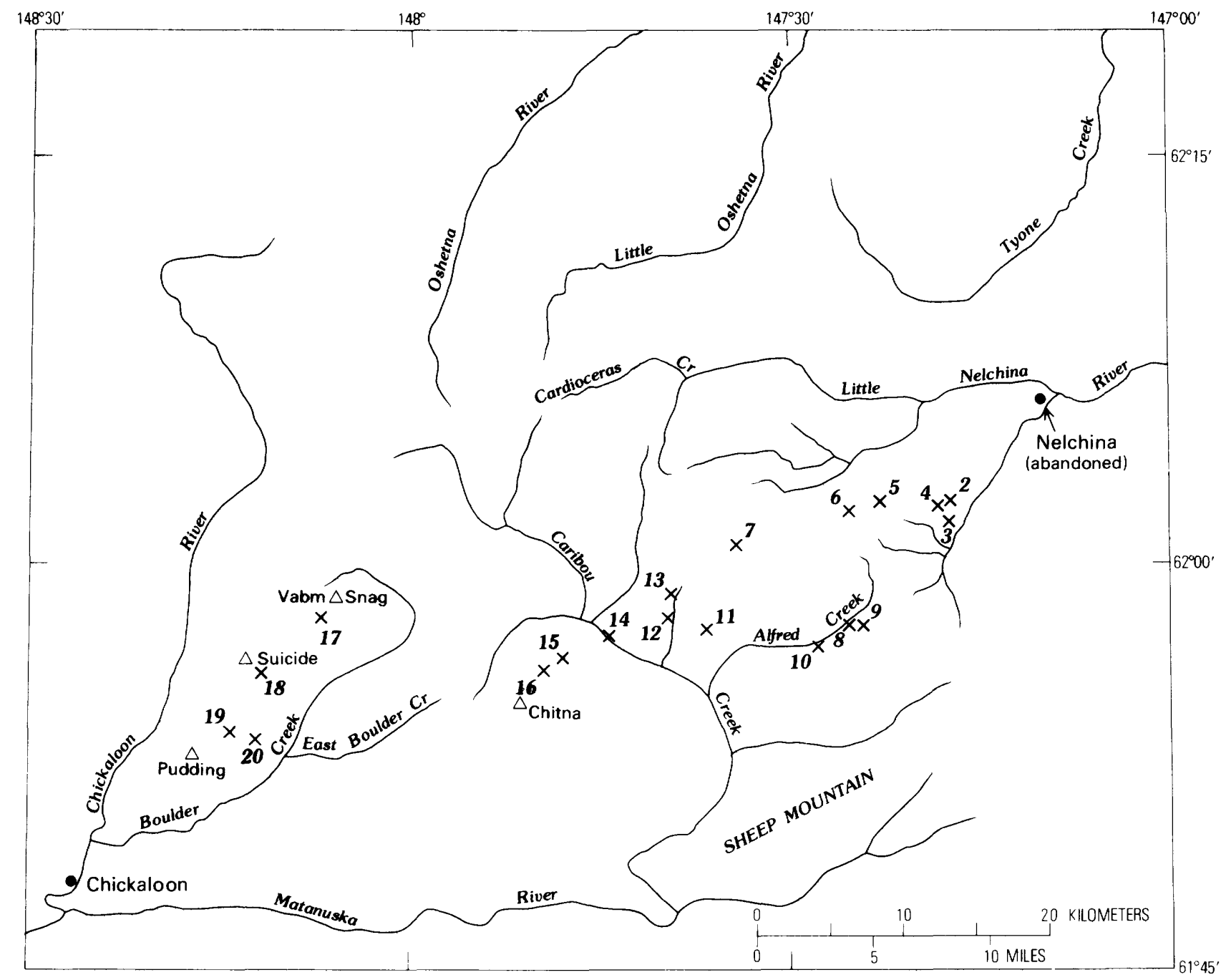

FiguRE 3.-Listed early and middle Bajocian ammonite localities in the Talkeetna Mountains. Numbers refer to those given in table 5. 


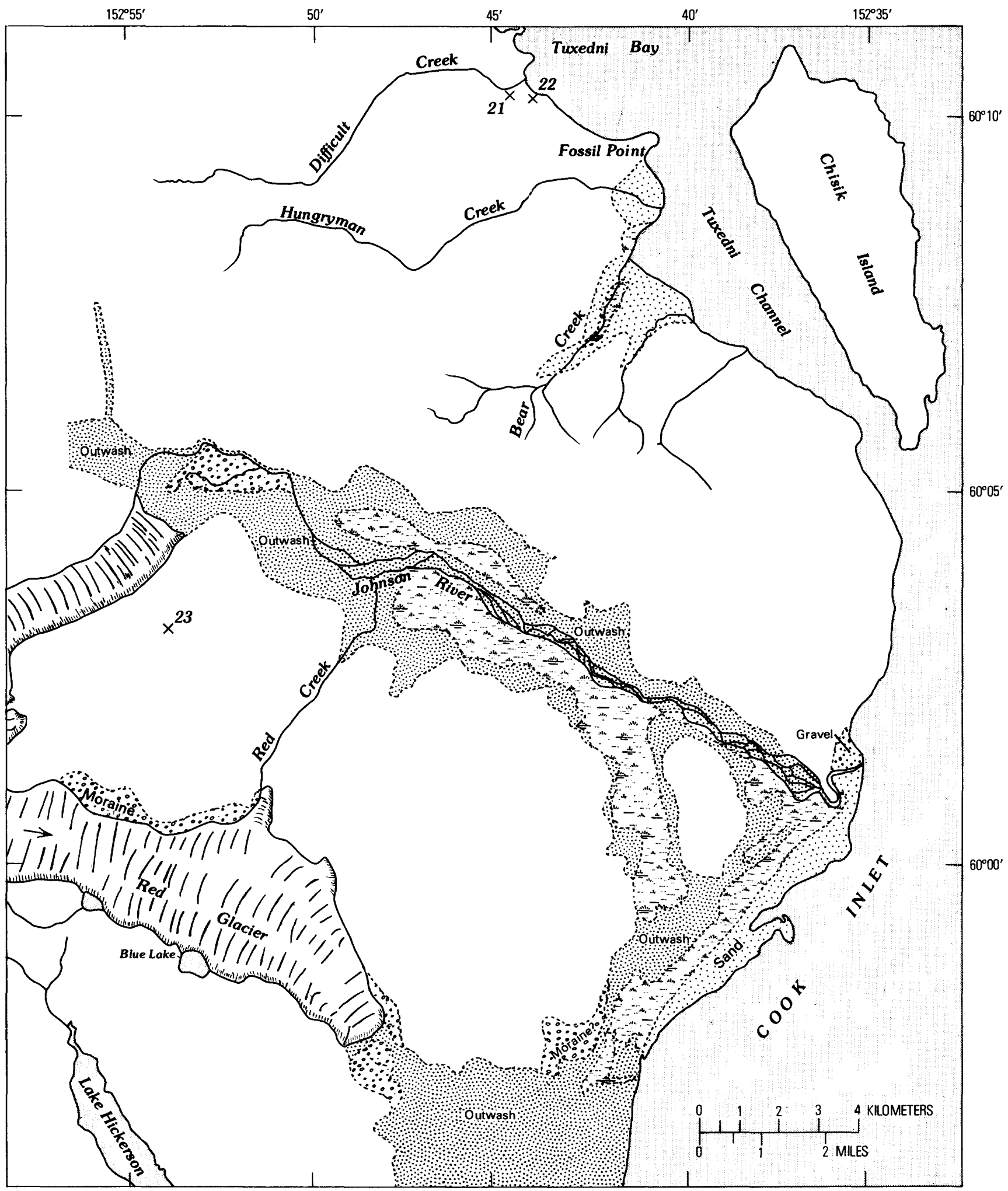

Figure 4.-Listed early and middle Bajocian ammonite localities at the west side of Cook Inlet between Tuxedni Bay and Chinitna Bay. Numbers refer to those given in table 5. 


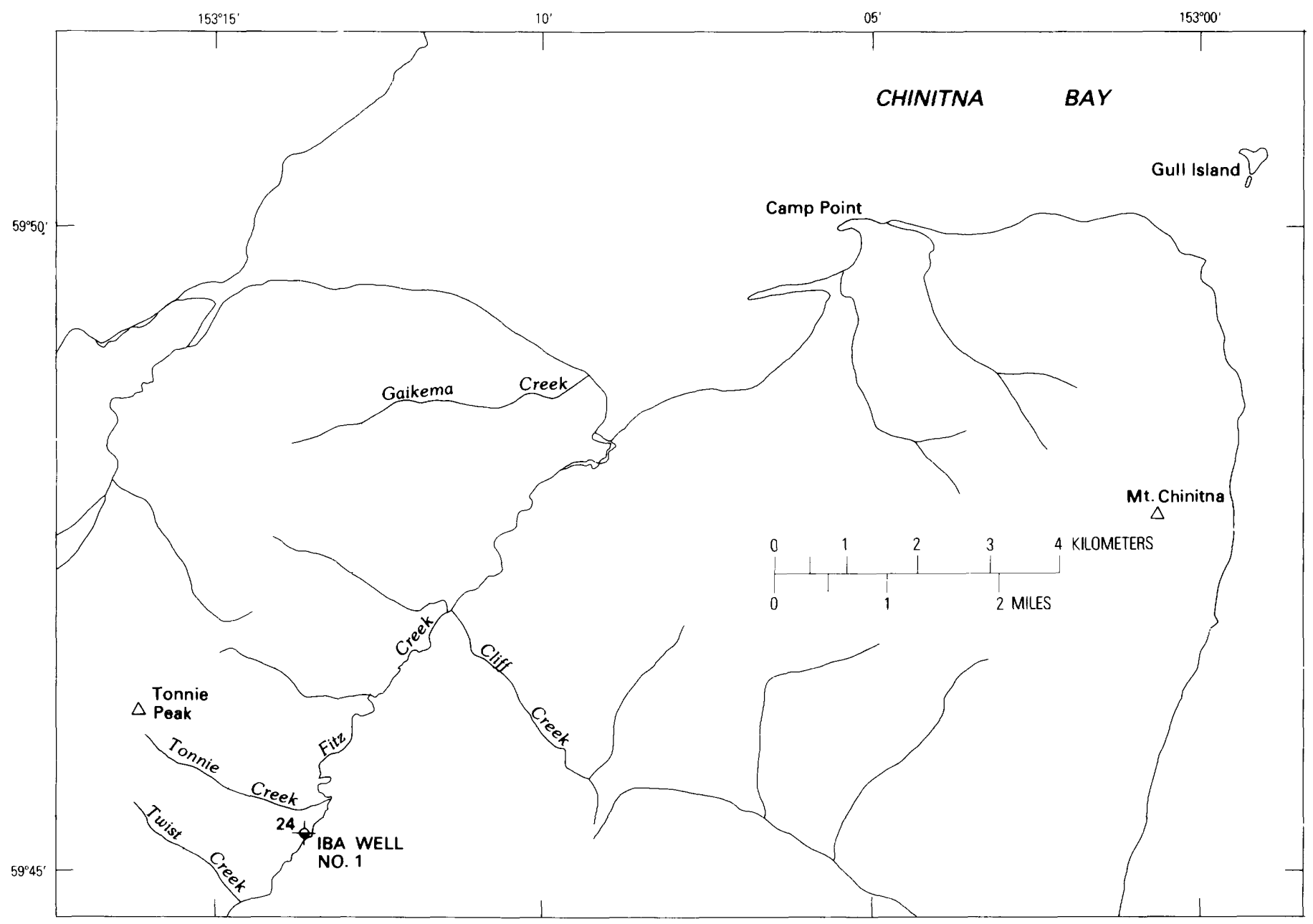

FIGURE 5.-Listed early and middle Bajocian ammonite locality west of Cook Inlet on the Iniskin Peninsula in the Iniskin Bay Association well 1. Number refers to that given in table 5 .

about 6 percent; and the Lytoceratidae, Strigoceratidae, and Haploceratidae combined, only $1 \frac{1}{2}$ percent. The characteristics of most of the genera, subgenera and species present have been discussed by the writer in previous publications (Imlay, 1964, p. B3-B6; 1973, p. 3-8), and are not repeated herein.

\section{STRATIGRAPHIC SUMMARY}

\section{WRANGELL MOUNTAINS}

The Middle Jurassic is represented in the Wrangell Mountains (fig. 8) only by the Nizina Mountain Formation, which consists mostly of medium-bedded graywacke, attains a maximum thickness of $1,500 \mathrm{ft}$ $(457 \mathrm{~m})$, is overlain unconformably by the Root Glacier Formation of Oxfordian to Kimmeridgian (Late Juras- sic) age, and is underlain unconformably by the Lubbe Creek Formation of Hettangian to Pliensbachian (Early Jurassic) age (MacKevett, 1969, p. A42-A46; 1971, p. 16, 17, 30, 31; Imlay and Detterman, 1973, p. 11A). From the base to near the middle part of the Nizina Mountain Formation, ammonites have been obtained that are probably of earliest Bathonian age (Imlay, 1980, p. 4, 12-14, 16). In addition, a few ammonites (fig. 2) of middle Bajocian age have been collected as float, along with many ammonites of probable early Bathonian age at U.S. Geological Survey Mesozoic loc. 28682 (MacKevett, 1969, p. A42-A43; 1971, p. 16, 17 , 30, 31; Imlay, 1980, p. 12-17, 21). These middle Bajocian ammonites were probably derived from the basal part of the Nizina Mountain Formation, or from underlying beds. 


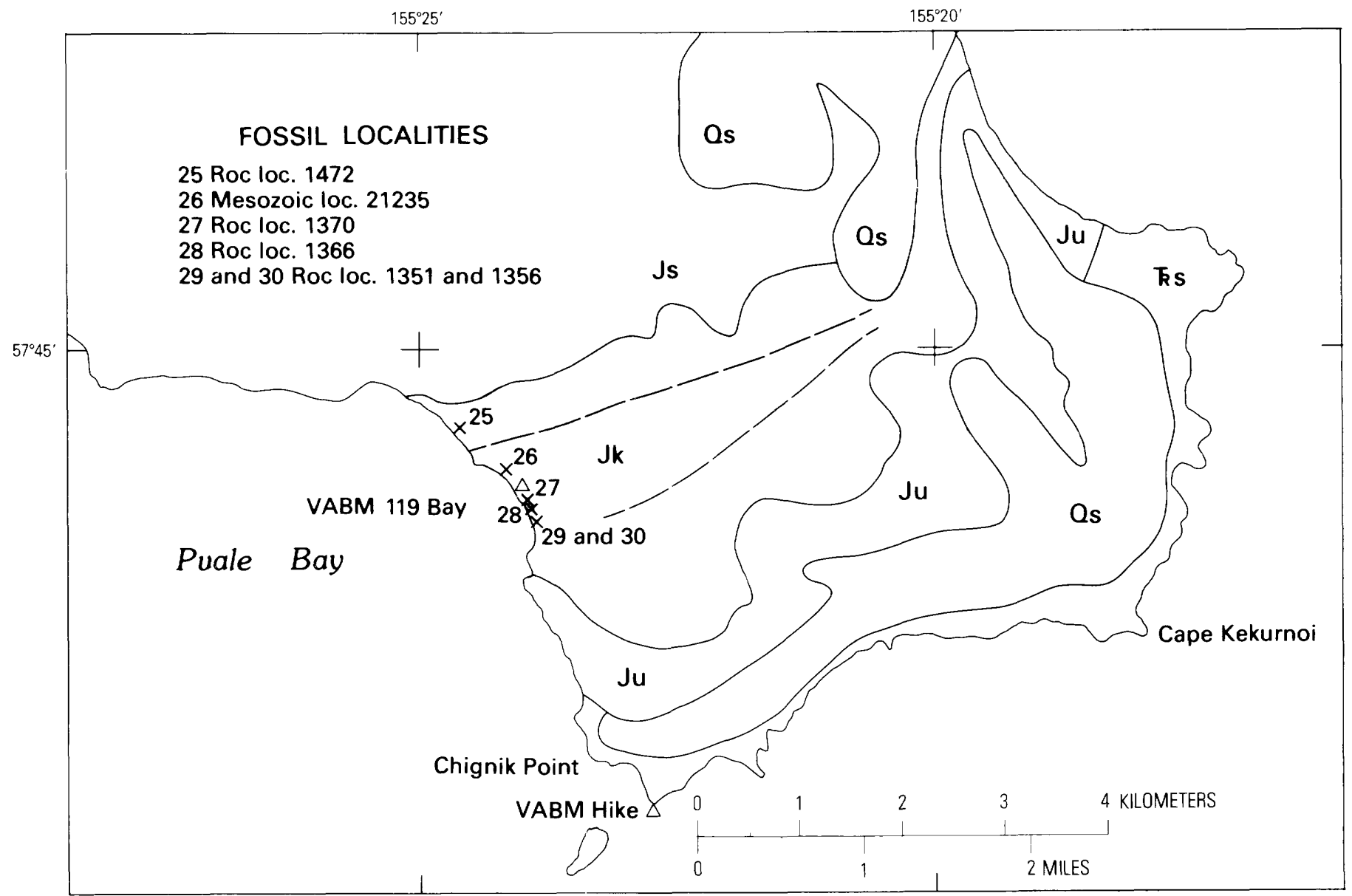

FIGURE 6.-Listed early and middle Bajocian ammonite localities northeast of Puale Bay on the Alaska Peninsula. The ROC localities represent fossil collections of the Richfield Oil Company. Qs, Quaternary sediments; Js, Shelikof Formation (Middle Jurassic); Jk, Kialagvik Formation (Lower and Middle Jurassic); Ju, unnamed Lower Jurassic beds; TRu, unnamed Triassic beds. Dashed lines indicate major faults. Formational boundaries determined on the basis of unpublished field data obtained in 1980 and 1981 by R.C. Detterman and associated USGS geologists.

\section{TALKEETNA MOUNTAINS}

In the Talkeetna Mountains, the Tuxedni Group is listed as $700-1,200 \mathrm{ft}(213-366 \mathrm{~m})$ thick (Imlay and Detterman, 1973, p. 11), and it has been identified at many places over a distance of $30 \mathrm{mi}(48 \mathrm{~km})$ from the Nelchina area in the east to the Boulder Creek area in the west (fig. 3). In the Nelchina area as far west as Sheep Creek, the Tuxedni Group, according to Arthur Grantz (written commun., 1981), consists basally of a sandstone that is more than $500 \mathrm{ft}(152 \mathrm{~m})$ thick at the headwaters of Flat Creek and about $850 \mathrm{ft}(260 \mathrm{~m})$ thick near Sheep Creek. Above the sandstone is siltstone that locally contains a few sandstone beds and is about $100 \mathrm{ft}(30 \mathrm{~m})$ thick.
In the Boulder Creek area of the Talkeetna Mountains the Tuxedni Group is not exposed basally, but is at least $550 \mathrm{ft}(168 \mathrm{~m})$ thick and well exposed on a divide $9.6 \mathrm{~km} \mathrm{~N}$. $20^{\circ} \mathrm{E}$. of the junction of Boulder Creek with East Boulder Creek (loc. 17 on fig. 3). Its uppermost beds consist of orange-red siltstone that is at least $30 \mathrm{ft}(9 \mathrm{~m})$ thick locally and is probably as much as $131 \mathrm{ft}(40 \mathrm{~m})$ thick. Below the orange-red siltstone the Tuxedni Group is represented by about $511 \mathrm{ft}(159 \mathrm{~m})$ of sedimentary rocks, consisting, from top to bottom, of $145 \mathrm{ft}(44 \mathrm{~m})$ of brown-to-gray siltstone, $100-136 \mathrm{ft}(30-41 \mathrm{~m})$ covered, $100 \mathrm{ft}(30.5 \mathrm{~m})$ of sandstone and grit, and $150 \mathrm{ft}(46 \mathrm{~m})$ of siltstone containing some beds of graywacke. This sequence has been illustrated previously (Imlay, 1980, figs. 3, 4; p. $10,11)$. 


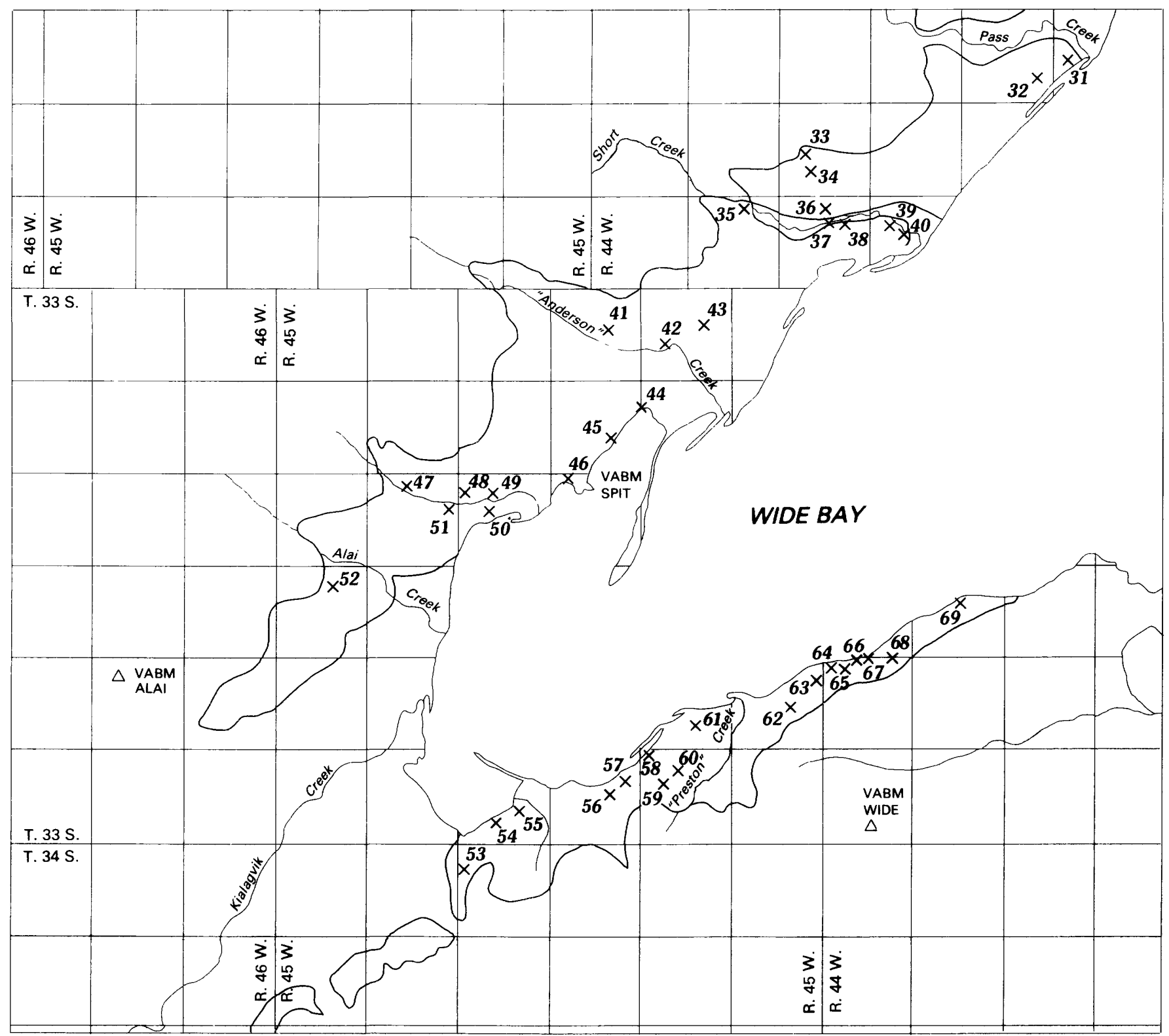

FIGURE 7.-Listed early and middle Bajocian ammonite localities at Wide Bay on the Alaska Peninsula. Heavy lines indicate contact of Kialagvik Formation. Numbers refer to those given in table 5. 
TABLE 1.-Early and middle Bajocian (Middle Jurassic) ammonite genera and subgenera in southern Alaska shouing biological relationships and relative numbers anailable for study

\begin{tabular}{|c|c|c|c|}
\hline Family & Subfamily & Genus or subgenus & Number of specimens \\
\hline \multirow[t]{3}{*}{ Phylloceratidae. } & \multirow[t]{2}{*}{ Phylloceratinae ...... } & 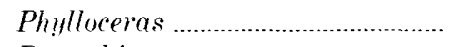 & 3 \\
\hline & & 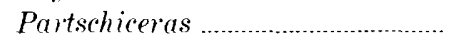 & 33 \\
\hline & Calliphyloceratinae …………….......... & 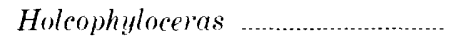 & 33 \\
\hline Lytoceratidae & Lytoceratinae & 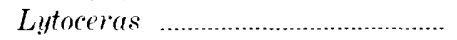 & 15 \\
\hline \multirow[t]{4}{*}{ Hildoceratidae } & Harpoceratinae & Pseudolioceras & 35 \\
\hline & Grammoceratinae & 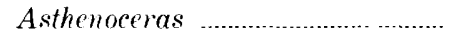 & 4 \\
\hline & Tmetoceratinae & 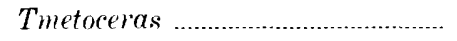 & 34 \\
\hline & & (Tmetoites) & 11 \\
\hline \multirow[t]{7}{*}{ Hammatoceratidae } & Hammatoceratinae & 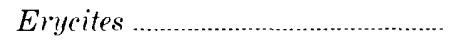 & 3 \\
\hline & & Erycitoides & 207 \\
\hline & & (Kialagvikes) & 57 \\
\hline & & 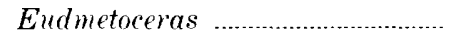 & 6 \\
\hline & & 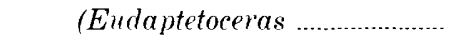 & 40 \\
\hline & & 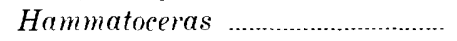 & 1 \\
\hline & & 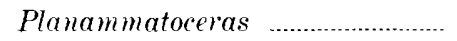 & 4 \\
\hline \multirow[t]{9}{*}{ Sonniniidae } & & 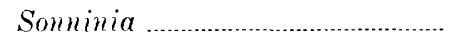 & 16 \\
\hline & & (Euhoploceras) & 38 \\
\hline & & 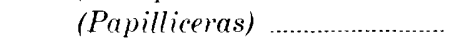 & 14 \\
\hline & & (Alaskinia) & 12 \\
\hline & & (Sominites) & 2 \\
\hline & & 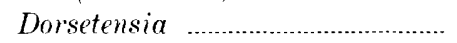 & 3 \\
\hline & & 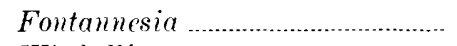 & 1 \\
\hline & & 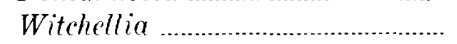 & 11 \\
\hline & & 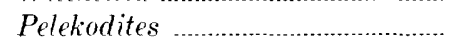 & 2 \\
\hline \multirow[t]{2}{*}{ Strigoceratidae } & 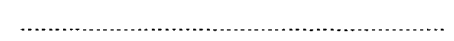 & 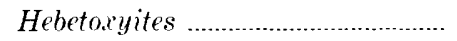 & 2 \\
\hline & & 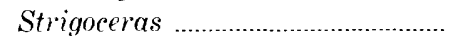 & 2 \\
\hline Haploceratidae & & Lissoceras ... & 4 \\
\hline Oppeliidae ................ & Oppeliinae & Bradfordia & 66 \\
\hline & & 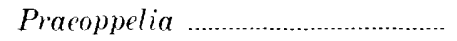 & 8 \\
\hline \multirow[t]{7}{*}{ Otoitidae } & & Docidoceras ........................ & 1 \\
\hline & & (Pseudocidoceras) & 53 \\
\hline & & 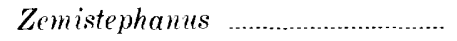 & 100 \\
\hline & & Otoites & 6 \\
\hline & & 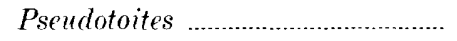 & 10 \\
\hline & & 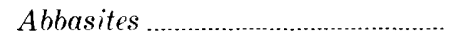 & 5 \\
\hline & & 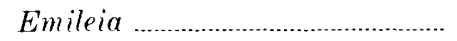 & 9 \\
\hline \multirow[t]{2}{*}{ Sphaeroceratidae } & & 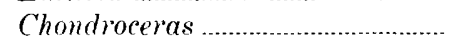 & 79 \\
\hline & & 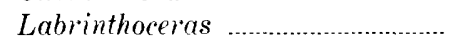 & 13 \\
\hline \multirow[t]{6}{*}{ Stephanoceratidae } & 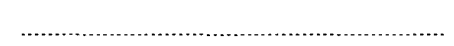 & 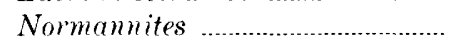 & 92 \\
\hline & & 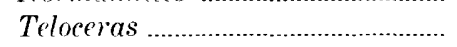 & 30 \\
\hline & & 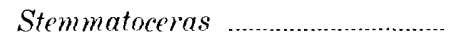 & 10 \\
\hline & & 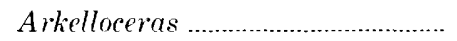 & 1 \\
\hline & & 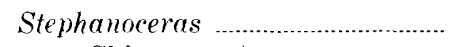 & 9 \\
\hline & & (Skirroceras) & 46 \\
\hline \multirow[t]{2}{*}{ Perisphinctidae } & 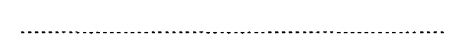 & Leptosphinctes & 1 \\
\hline & & 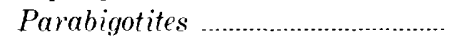 & 92 \\
\hline Total & & . & 1,224 \\
\hline
\end{tabular}




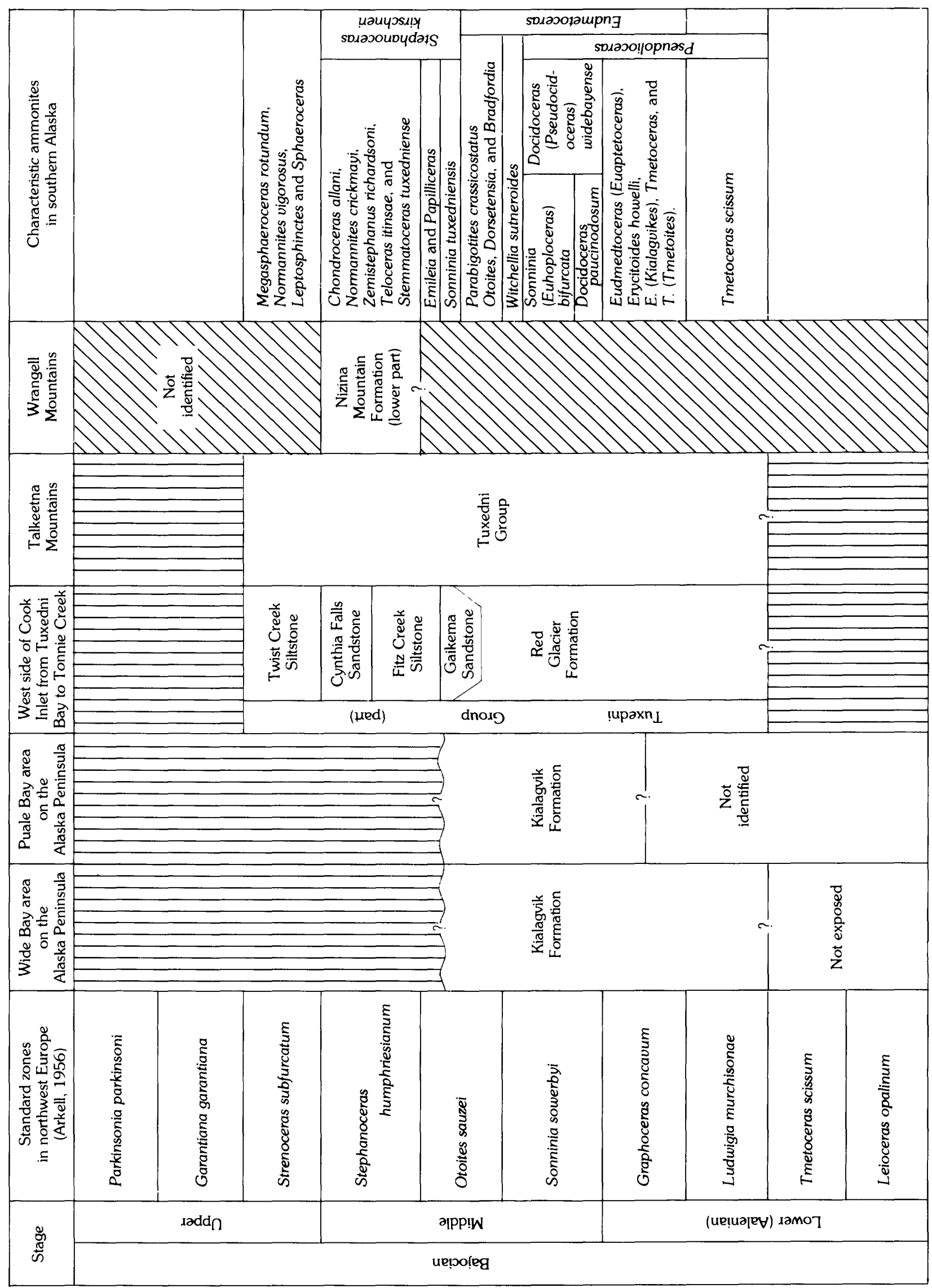




\section{WEST SIDE OF COOK INLET}

Lower and middle Bajocian beds are well exposed on the west side of Cook Inlet between Tuxedni Bay and Iniskin Bay (figs. 4, 9). They are represented from bottom to top by the Red Glacier Formation, the Gaikema Sandstone, the Fitz Creek Siltstone, and the Cynthia Falls Sandstone of the Tuxedni Group (figs. 8-9). These formations in combination thicken southward, from about 4,000 ft $(1,219 \mathrm{~m})$ north of Fossil Point on the south shore of Tuxedni Bay to nearly 8,000 $\mathrm{ft}(2,438 \mathrm{~m})$ near Red Glacier, about $11 \mathrm{mi}(17.6 \mathrm{~km})$ southwest of Fossil Point, but more than half of this thickening occurs in the Red Glacier Formation (Detterman and Hartsock, 1966, p. 22, 27, 30, 33). These formations, and the overlying Twist Creek Siltstone of early late Bajocian age constitute a conformable sequence overlain unconformably by the Bowser Formation of early to late Bathonian age (Imlay, 1980, p. 5-11), and underlain with angular unconformity by the Talkeetna Formation of Early Jurassic age. The evidence for the basal unconformity is well shown by exposures along the south shore of Tuxedni Bay north of Fossil Point and near Red Glacier. Farther south, the Red Glacier Formation in many places is in fault contact with older formations, and in other places its lower part is not exposed. Considerably more lithologic and stratigraphic data concerning these formations have been presented by Detterman and Hartsock (1966, p. 20-34, tables 1-7).

\section{PUALE bAy AREA ON THE ALASKA PENINSULA}

The lithologic and stratigraphic features of the Kialagvik Formation exposed on the northeast side of Puale Bay have been described by Capps (1922, p. 90-94), Smith and Baker (1924, p. 169-173), Smith (1926, p. 66-72), Martin (1926, p. 182-186), and Kellum, Davies, and Swinney (1945). A summary description of those features has been presented more recently by Imlay and Detterman (1977, p. 607-611). As shown herein on figure 10, the Kialagvik Formation consists from bottom to top of three units. The lower unit is $1,300 \mathrm{ft}(396 \mathrm{~m})$ thick, consists mostly of dark-gray-toblack sandy siltstone, but includes many limestone concretions in its upper $850 \mathrm{ft}(259 \mathrm{~m})$. The middle unit is about $100 \mathrm{ft}(30 \mathrm{~m})$ thick, consists partly of igneous pebbles and boulders, but includes much coarse sandstone. The upper unit is about $500 \mathrm{ft}(152 \mathrm{~m})$ thick, consists mostly of gray siltstone, contains some ash and limestone concretions, and weathers gray. The basal beds of the formation near the beach rest sharply on beds of Early Jurassic age, but inland toward Alinchak Bay the basal beds are reported by R. L. Detter- man (personal commun., 1981) to pass conformably downward into beds of Early Jurassic age.

\section{WIDE BAY AREA ON THE ALASKA PENINSULA}

The Kialagvik Formation exposed along the northwest side of Wide Bay has been described by Kellum, Davies, and Swinney (1945, p. 4-8, figs. 1,2) mainly on the basis of the sequences on and near Short Creek and Anderson Creek. They note that the formation on Short Creek is about $1,750 \mathrm{ft}(533 \mathrm{~m})$ thick, consists mostly of shale, siltstone, and sandy shale but includes some sandstone and conglomerate, and its basal 600 $\mathrm{ft}(183 \mathrm{~m})$ of beds is older than the basal beds exposed elsewhere near Wide Bay. According to Kellum, Davies, and Swinney, the Kialagvik Formation at Short Creek from top to bottom is divisible into the following lithologic units (fig. 11):

Unit 1, at the top, consists of about $331 \mathrm{ft}(91 \mathrm{~m})$ of calcareous concretionary shaly siltstone and sandy shale that includes one bed of limestone about $60 \mathrm{ft}$ (18 $m)$ below the top and one bed of sandstone about $200 \mathrm{ft}$ $(61 \mathrm{~m})$ below the top. This unit has furnished Inoceramus lucifer Eichwald, a few fragmentary ammonites, and a well-preserved specimen of Sonninia tuxedniensis Imlay.

Unit 2 consists of about $128 \mathrm{ft}$ ( $58 \mathrm{~m}$ ) of siltstone and sandy shale that contains some concretions, becomes sandier upwards, and contains beds of sandstone at its top and bottom. The upper half of this unit has furnished the ammonite genera Parabigotites, Bradfordia, Eudmetoceras, Stephanoceras, Stemmatoceras, and Arkelloceras.

Unit 3 consists of about $164 \mathrm{ft}(50 \mathrm{~m})$ of blocky dark-gray shale that has not furnished any ammonites.

Unit 4 consists of about $190 \mathrm{ft}(58 \mathrm{~m})$ of interbedded sandstone and sandy shale that is coarser toward the top and includes several beds of conglomerate whose pebbles were derived from metamorphic rocks and attain diameters of 75-100 mm. This unit has furnished such ammonites as Erycitoides howelli (White), E.(Kialagvikites) kialagvikensis(White), Pseudolioceras whiteavesi (White), Tmetoceraskirki Westermann, and T. (Tmetoides) tenue Westermann.

Unit 5 is $366 \mathrm{ft}(126 \mathrm{~m})$ thick and is mostly covered. It apparently consists, however, mostly of poorly exposed gray-to-black shale, siltstone, and sandy shale. The unit also includes four widely spaced, fairly well exposed beds of gray sandstone that are interbedded with some sandy shale and have furnished ammonites. Such beds, from 240 to $259 \mathrm{ft}(73-79 \mathrm{~m})$ below the top of the unit, have furnished the same kinds of ammonite that occur in unit 4 . Similar beds at the base of the unit and also about $328 \mathrm{ft}(100 \mathrm{~m})$ higher have furnished the ammonite Tmetoceras scissum (Benecke). 


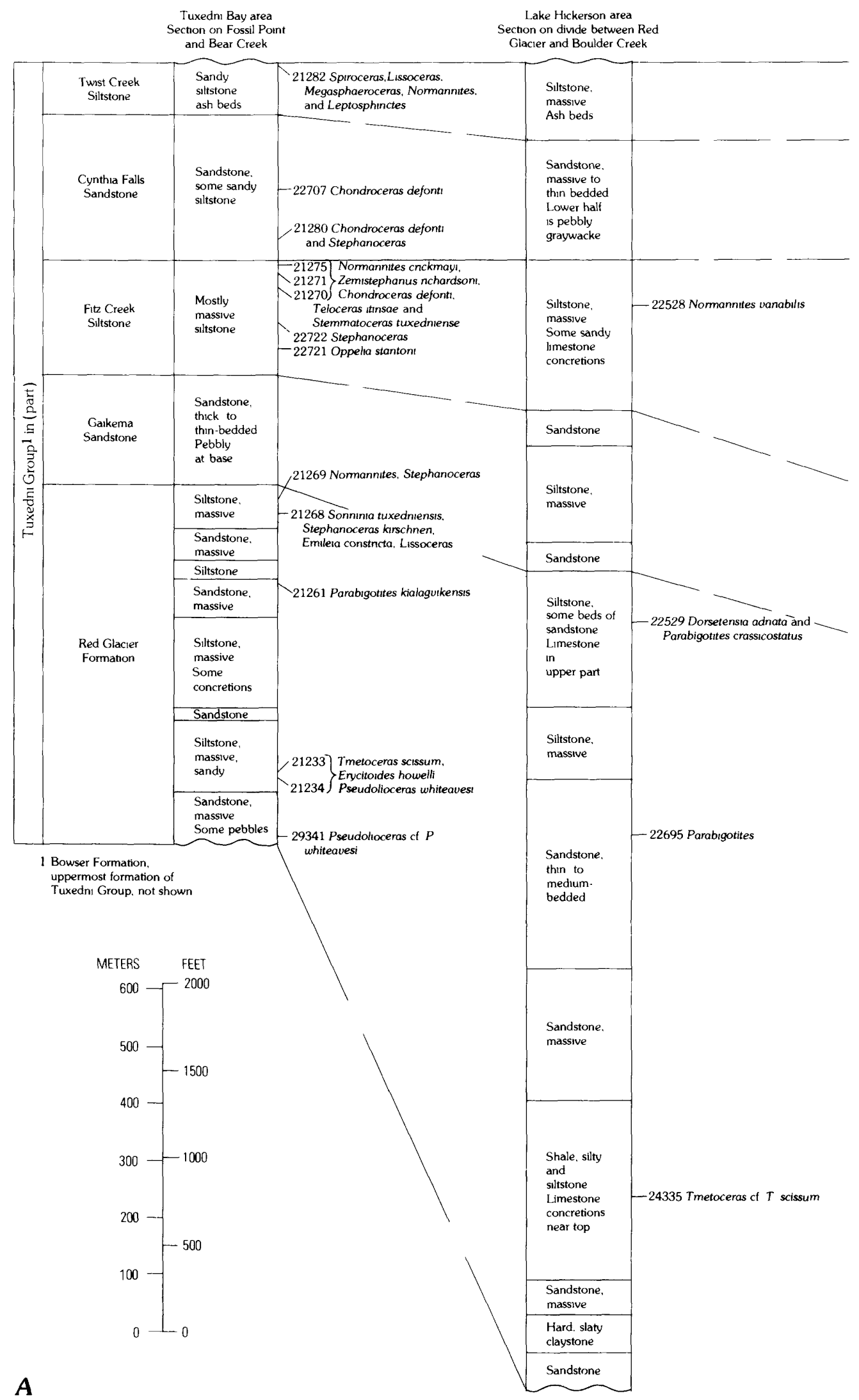

FIGURE 9. $-A$, Stratigraphic positions of some Bajocian ammonite localities west of Cook Inlet between Survey Mesozoic localities. $B$, Chart showing 


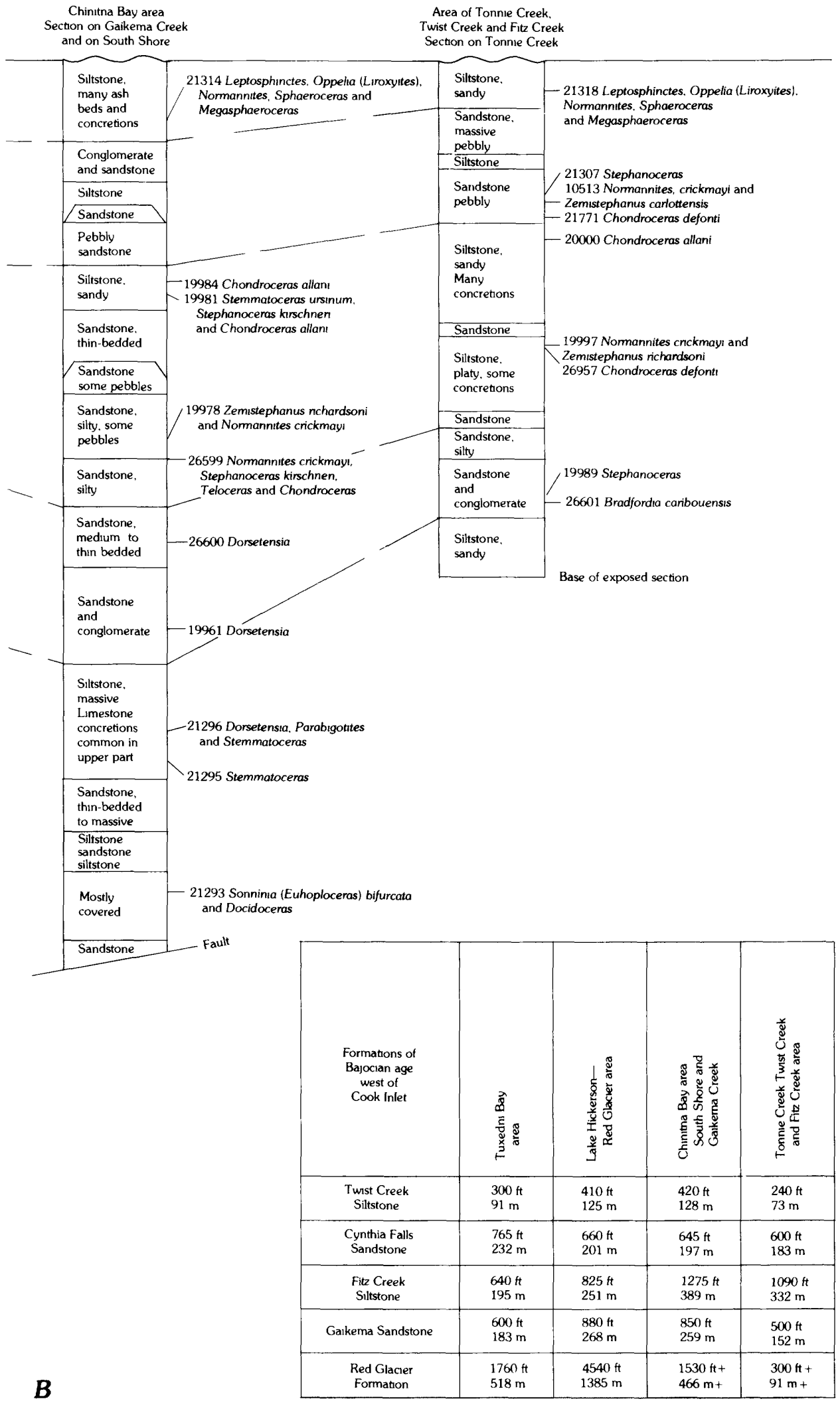

Tuxedni Bay and Iniskin Bay (data from Detterman and Hartsock, 1966). Numbers refer to U.S. Geological thicknesses of formations in various areas. 
EARLY AND MIDDLE BAJOCIAN AMMONITES FROM SOUTHERN ALASKA

\begin{tabular}{|c|c|c|c|}
\hline Formation & Description & Charactenstic Fossils & Stage \\
\hline $\begin{array}{l}\text { Shelikof Formation } \\
\text { (lowest part) }\end{array}$ & $\begin{array}{l}\text { Siltstone. gray. } \\
\text { weathers brown, } \\
\text { contains ash beds }\end{array}$ & $\begin{array}{c}-3106 \text { Codoceras tenuicostatum and } \\
C \text { (Stenocadoceras) Iniskinense }\end{array}$ & $\begin{array}{l}\text { Late early } \\
\text { Callovian }\end{array}$ \\
\hline \multirow{6}{*}{ Kialagvik Formation } & \multirow[b]{2}{*}{$\begin{array}{l}\text { Siltstone, gray. } \\
\text { weathers gray. } \\
\text { does not contain } \\
\text { ash beds } \\
152 \mathrm{~m}(500 \mathrm{ft})\end{array}$} & \multirow[t]{3}{*}{ - ROC 1472 Dorsetensia? or Witchellia? sp juv } & \multirow[t]{3}{*}{ Middle middle Bajocian } \\
\hline & & & \\
\hline & $\begin{array}{l}\text { Conglomerate and } \\
\text { coarse sandstone } \\
30 \mathrm{~m}(100 \mathrm{ft})\end{array}$ & & \\
\hline & $\begin{array}{l}\text { Siltstone, sandy, } \\
\text { dark-gray to black } \\
\text { Contain thin beds } \\
\text { of hard, buff } \\
\text { sandstone and } \\
\text { becomes sandier } \\
\text { Limestone concretions } \\
\text { common in } \\
\text { upper } 259 \mathrm{~m} \text { ( } 850 \mathrm{ft} \text { ) }\end{array}$ & $\begin{array}{l}\text {-21235 Fontannesia of } F \text { carinata Buckman. } \\
\text { Bradfordia costidensa Imiay and } \\
\text { Inoceramus lucifer (Eichwald) }\end{array}$ & $\begin{array}{l}\text { Late early or early } \\
\text { middle Bajocian }\end{array}$ \\
\hline & \multirow{2}{*}{$\begin{array}{l}\text { Total thickness } \\
396 \mathrm{~m}(1300 \mathrm{ft})\end{array}$} & $\begin{array}{l}\text { ROC } 1370 \text { Tmetoceras scissum (Benecke) and } \\
\text { Erycitoides (Kialaguikes) levis Westermann } \\
\text { ROC } 1366 \text { Tmetoceras scissum (Benecke) and } \\
\text { Erycitoides (Kialaguikes) sp } \\
\text { ROC } 1351 \text { and } 1356 \text { Pseudolioceras whiteavesi, } \\
\text { (White) and Erycitoides (Kialaguikes) sp }\end{array}$ & Graphoceras concavum zone \\
\hline & & \multirow{2}{*}{$\begin{array}{l}\text { - } 19804 \text { Haugia spp. and Pseudolioceras sp } \\
\text { Fault contact } \\
\text { ROC } 1303 \text { Coroniceras? sp }\end{array}$} & Late early Toarcian \\
\hline $\begin{array}{l}\text { Unnamed } \\
\text { Lower Jurassic beds } \\
\text { (highest part) }\end{array}$ & 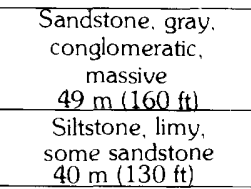 & & Early Sinemurian \\
\hline
\end{tabular}

Frgure 10.-Stratigraphic positions of some Bajocian ammonite localities on the northeast side of Puale Bay on the Alaska Peninsula. Localities marked ROC were collected by the Richfield Oil Company. 
The sections measured by Kellum and others (1945, fig. 2) along the northwest side of Wide Bay show that unit 1 of the Short Creek section passes southwestward within $5 \mathrm{~km}$ of Anderson Creek, into a sequence consisting mostly of pebbly sandstone. Unit 2 , as determined by ammonites, passes southwestward at Anderson Creek into a sequence that consists mostly of siltstone and shaly-to-thin-bedded sandstone but that contains some pebbly beds at its top and some thin coal seams at its base. Unit 3 apparently passes southwestward on Anderson Creek into the lower part of some shaly beds that bear coal seams, but probably passes also into $60 \mathrm{ft}(18 \mathrm{~m})$ of beds represented mostly by a covered interval. Unit 4 is represented by cliff-forming conglomeratic sandstone on both creeks.

On an unnamed creek about $9 \mathrm{~km}(6 \mathrm{mi})$ southwest of Short Creek and 1.5-2.0 km north of Alai Creek, the Kialagvik Formation near its top bears pebbly sandstone similar in position to that at the top of the formation on Anderson Creek. At least $400 \mathrm{ft}$ (122 m) lower occur nearly $200 \mathrm{ft}$ ( $61 \mathrm{~m}$ ) of cliff-forming pebbly beds similar to the beds in unit 4 on Anderson Creek and Short Creek. The intervening beds are poorly exposed, are broken by faults, and are difficult to compare with the sequences exposed farther northeast.

On the southeast side of Wide Bay the same ammonites that are present in unit 2 at Short Creek are present in cliff-forming sandstone northeast of Preston Creek in the NW $1 / 4$ sec. 30, T. 33 S., R. 44 W. (USGS Mesozoic locs. 19822-19825) and in the NE corner of sec. 25, T. 33 S., R. 45 W. (USGS Mesozoic loc. 32290). Southwest of Preston Creek, unit 2 is likewise represented by ammonite-bearing cliff-forming sandstone in the south-central part of sec. 26 , T. 33 S., R. 45 W.(USGS Mesozoic loc. 19798) and in the south-central part of sec. 33, T. 33 S., R. 45 W. (USGS Mesozoic locs. 19742 and 19796). This sandstone is characterized faunally by the ammonites Parabigotites crassicostatus Buckman and Bradfordia costidensa Imlay.

On the southeast side of Wide Bay northeast of Preston Creek occur other beds that are probably equivalent to unit 3 of the Short Creek sequence. These beds consist mostly of fossiliferous shale that bears concretions, include two sandstone beds and some sandy-tosilty beds, and are at least $174 \mathrm{ft}(59 \mathrm{~m})$ thick. They are characterized faunally by the ammonites Docidoceras (Pseudocidoceras) widebayensis Westermann, Sonninia (Euhoploceras) bifurcata Westermann, and many other ammonite taxa (USGS Mesozoic locs. 19862, 19863, 19869, 21251, 21252, 31966, 32292, 32293, 32295 , and 32296).

On the southeast side of Wide Bay, about $3 \mathrm{~km}$ southwest of the mouth of Preston Creek (loc. 61 on fig. $15)$, the beds just mentioned are underlain at the base of a high bluff at Shell Oil Co. loc. L154 by beds containing the ammonites Tmetoceras kirki flexicostatum Westermann and T. (Tmetoites) cf. T. (T.) tenue Westermann $(1964$, p. $354 ; 1969$, p. 12). Such ammonites are characteristic of the upper part of the beds containing Erycitoides howelli (White), as in unit 4 of the Short Creek sequence. E. hovelli (White) itself has been found near the south end of the southeast side of Wide Bay in the SE $1 / 4$ sec. 33, T. 34 S., R. 45 W. at Shell Company loc. L555.

These data indicate that the lithologic units within the Kialagvik Formation change laterally within fairly short distances and, therefore, are difficult to correlate without fossils.

\section{AGES AND CORRELATIONS}

\section{WRANGELL MOUNTAINS}

The existence of beds of middle Bajocian age in the Wrangell Mountains is based on a few ammonites (fig. 8) representing the genera Chondroceras, Normannites, and Teloceras. These ammonites were collected as float at one place near the base of the Nizina Mountain Formation (USGS Mesozoic loc. 28682).

Of these genera, Chondroceras is common nearly worldwide in the Stephanoceras humphriesianum zone of the middle Bajocian (Imlay, 1973, p. 19) and is known from beds of late Bajocian age. Normannites ranges upward from the uppermost part of the Otoites sauzei zone of middle Bajocian age to the Strenoceras subfurcatum zone of early late Bajocian age. Teloceras ranges upward from the Stephanoceras humphriesiamum zone to the Garantia garantiana zone of the middle late Bajocian (Imlay, 1973, p. 19; Arkell, 1956, p. 483). The presence of Chondroceras is good evidence for a late middle Bajocian age. The presence of a species resembling Teloceras blagdeni (Sowerby) favors an age assignment not older than the upper part of the Stephanoceras humphriesianum zone (Weisert, 1932 , p. 185; Arkell, 1956, p. 483). Such an age assignment seems reasonable provided the three genera occur in association.

In addition, another ammonite faunule of slightly younger age has been found at the same locality as the 3 genera just listed as well as at 10 other localities ranging from the base to near the middle of the Nizina Mountain Formation (Imlay, 1980, p. 4). This younger faunule is herein considered to represent the earliest Bathonian rather than the latest Bajocian because (1) it does not contain typical late Bajocian ammonites, such as Spiroceras, Leptosphinctes, and Sphacroceras (Imlay, 1980, p. 4); (2) it does contain species typical of the earliest Bathonian, such as Cranocephalites cost $i$ densus (Imlay, 1980, p. 8); and (3) in the Lake Hickerson 


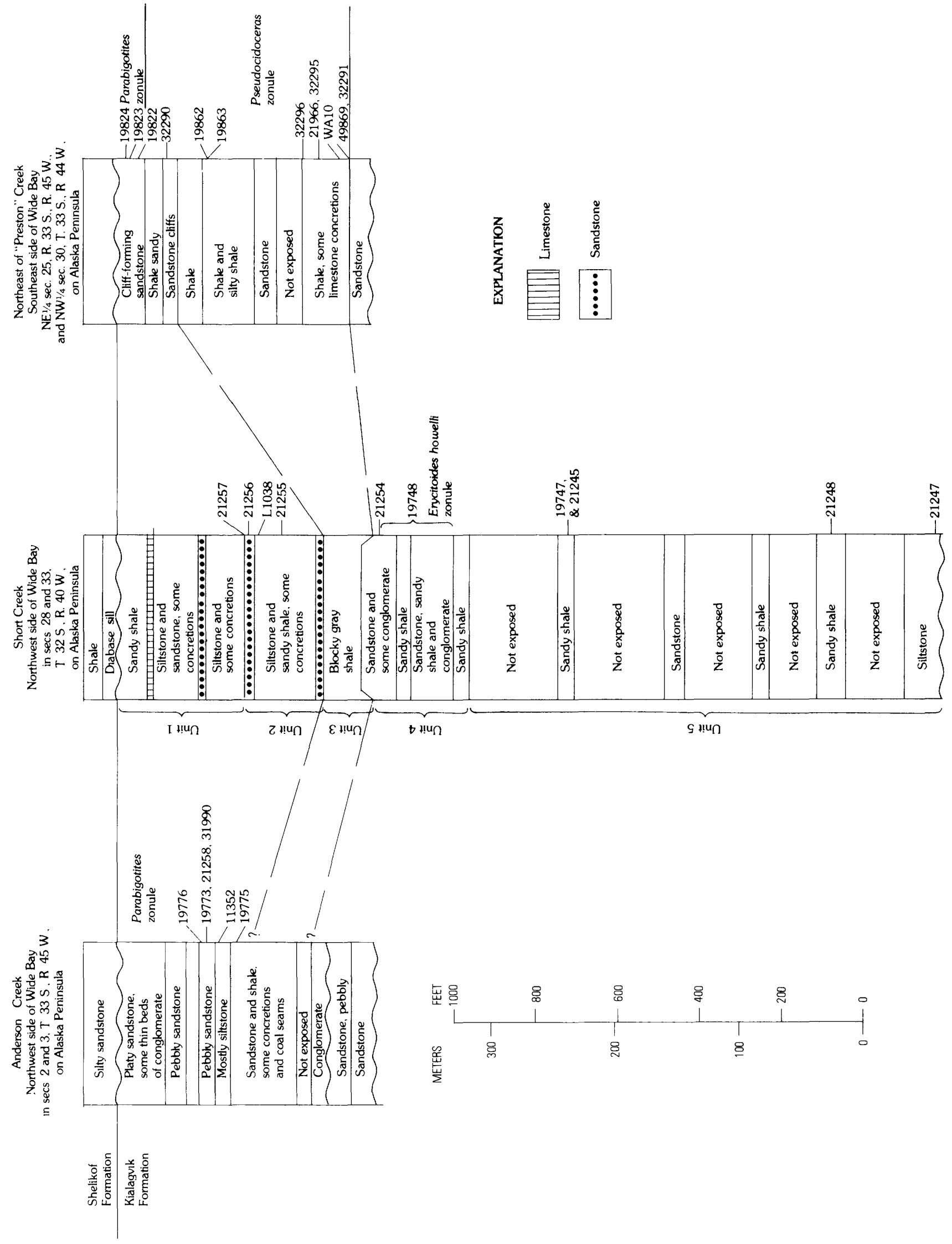



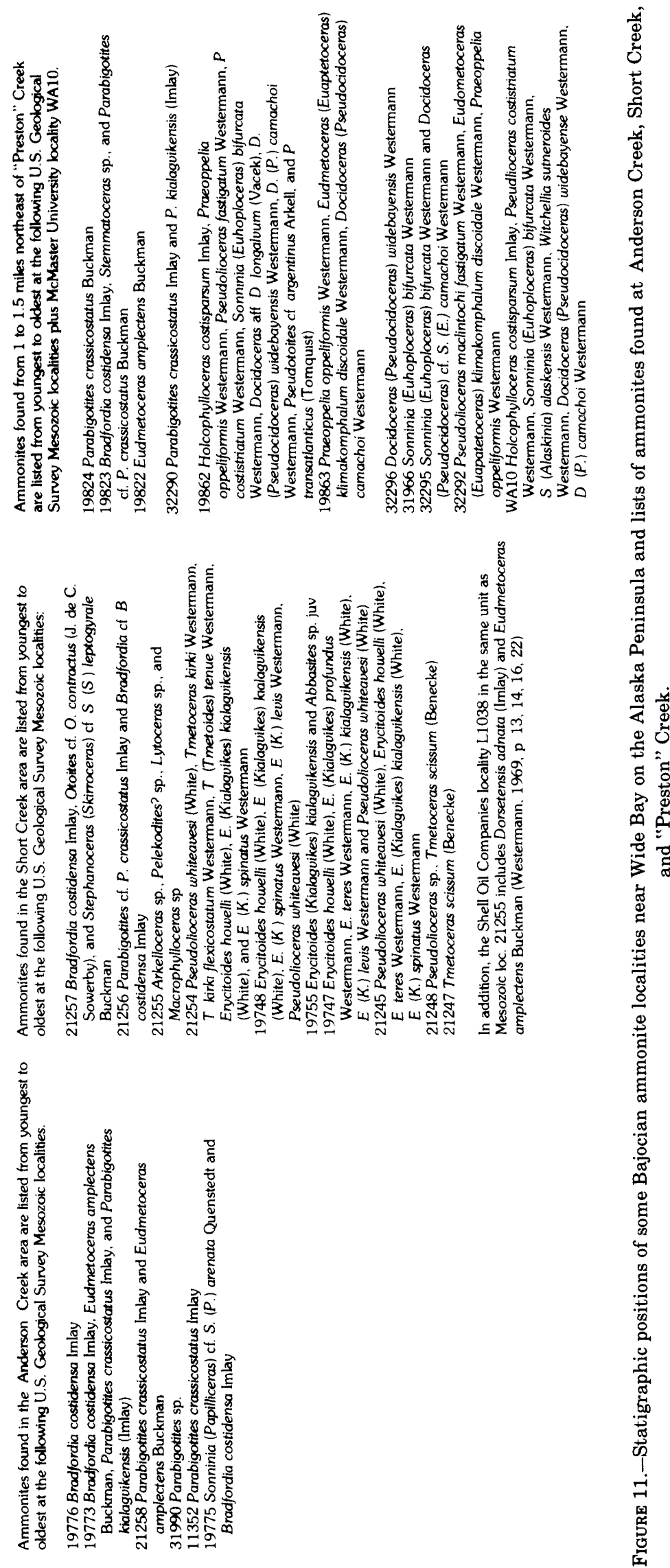


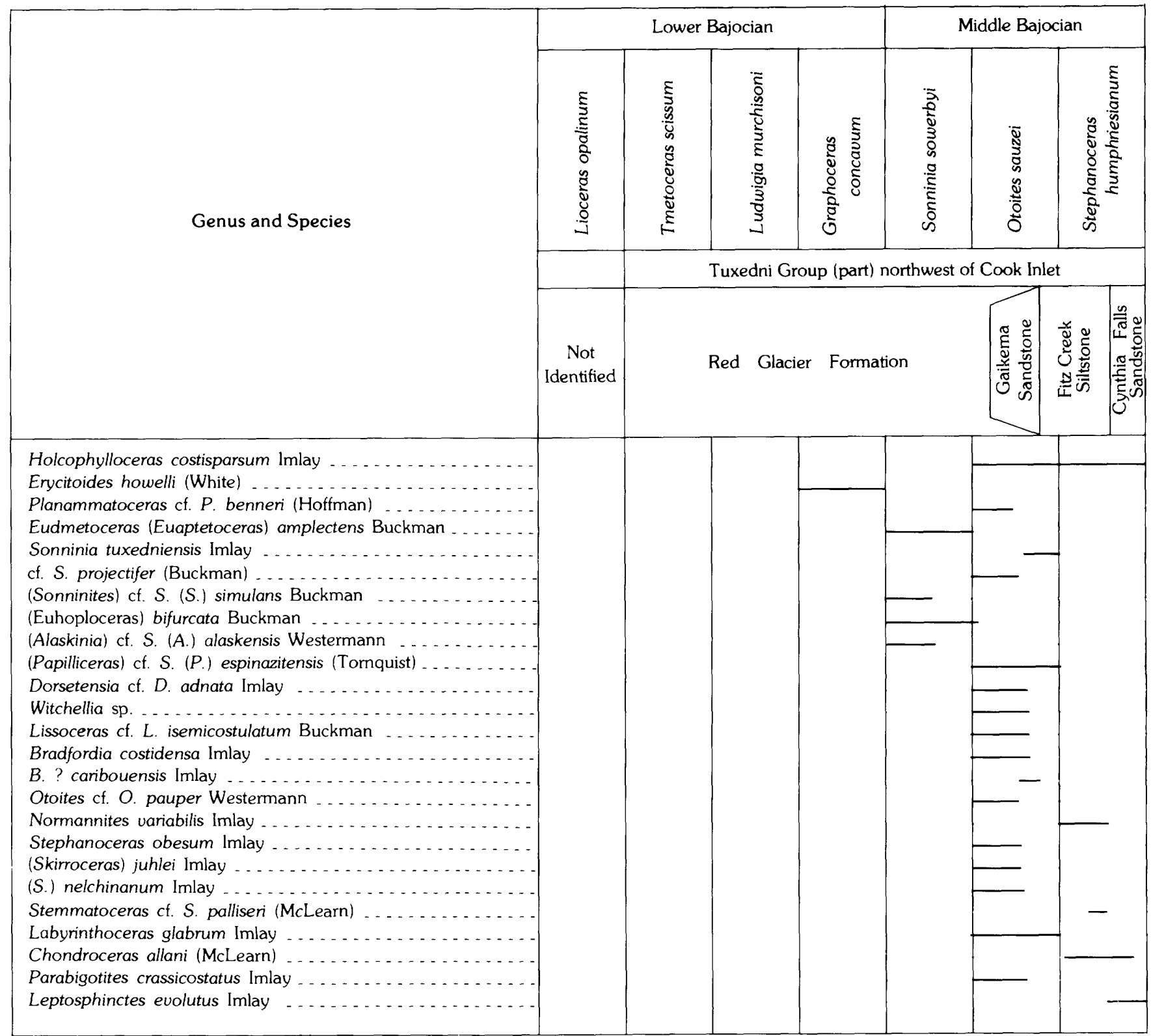

FIGURE 12.-Stratigraphic and chronologic correlations of some early and middle Bajocian ammonites present in the Talkeetna Mountains with ammonites present in the Tuxedni Group west of Cook Inlet. 


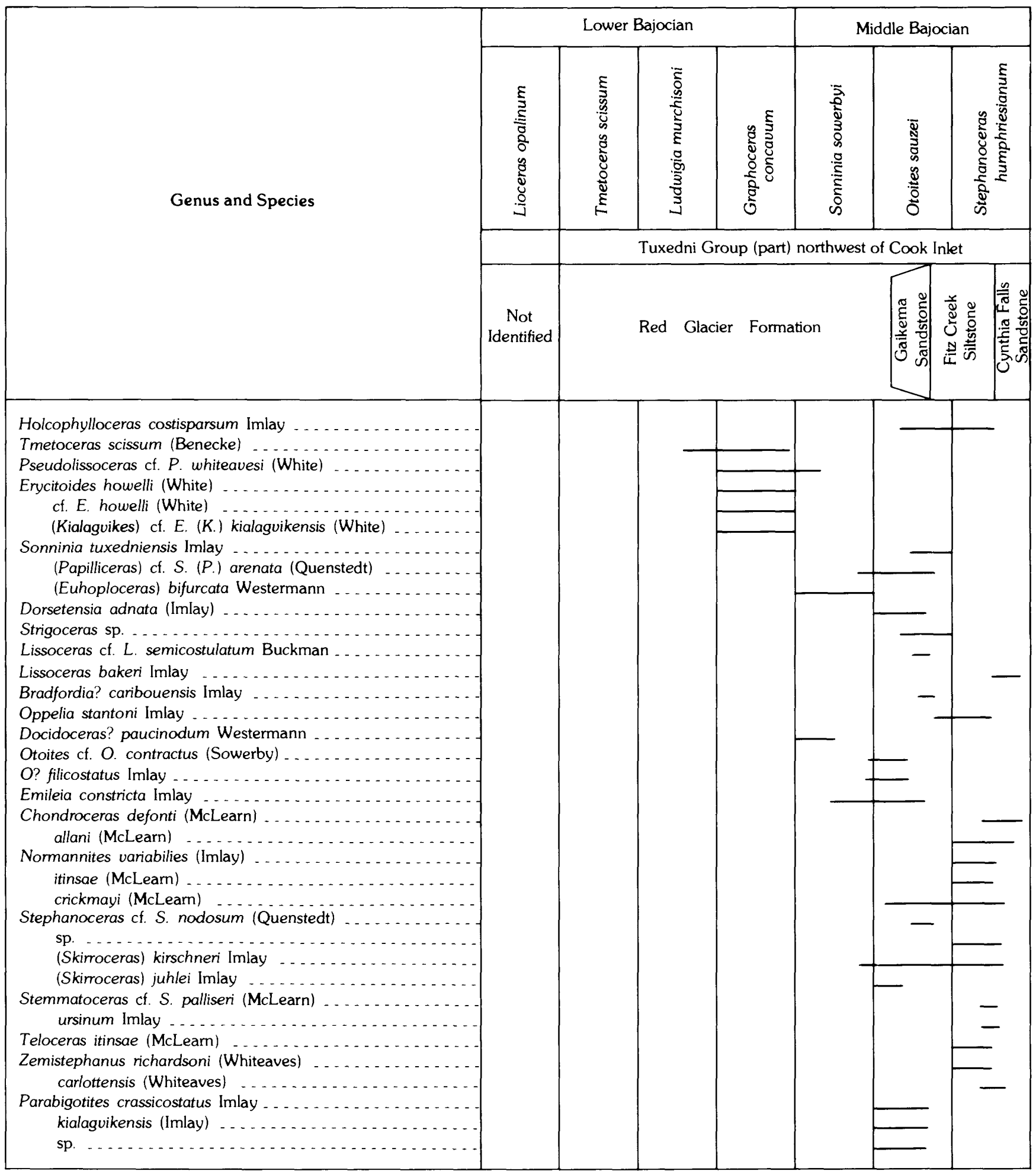

FIGURE 13.-Stratigraphic and chronologic correlations of some early and middle Bajocian ammonites present along the west side of Cook Inlet between the Fitz Creek and Tuxedni Bay areas in south-central Alaska. 


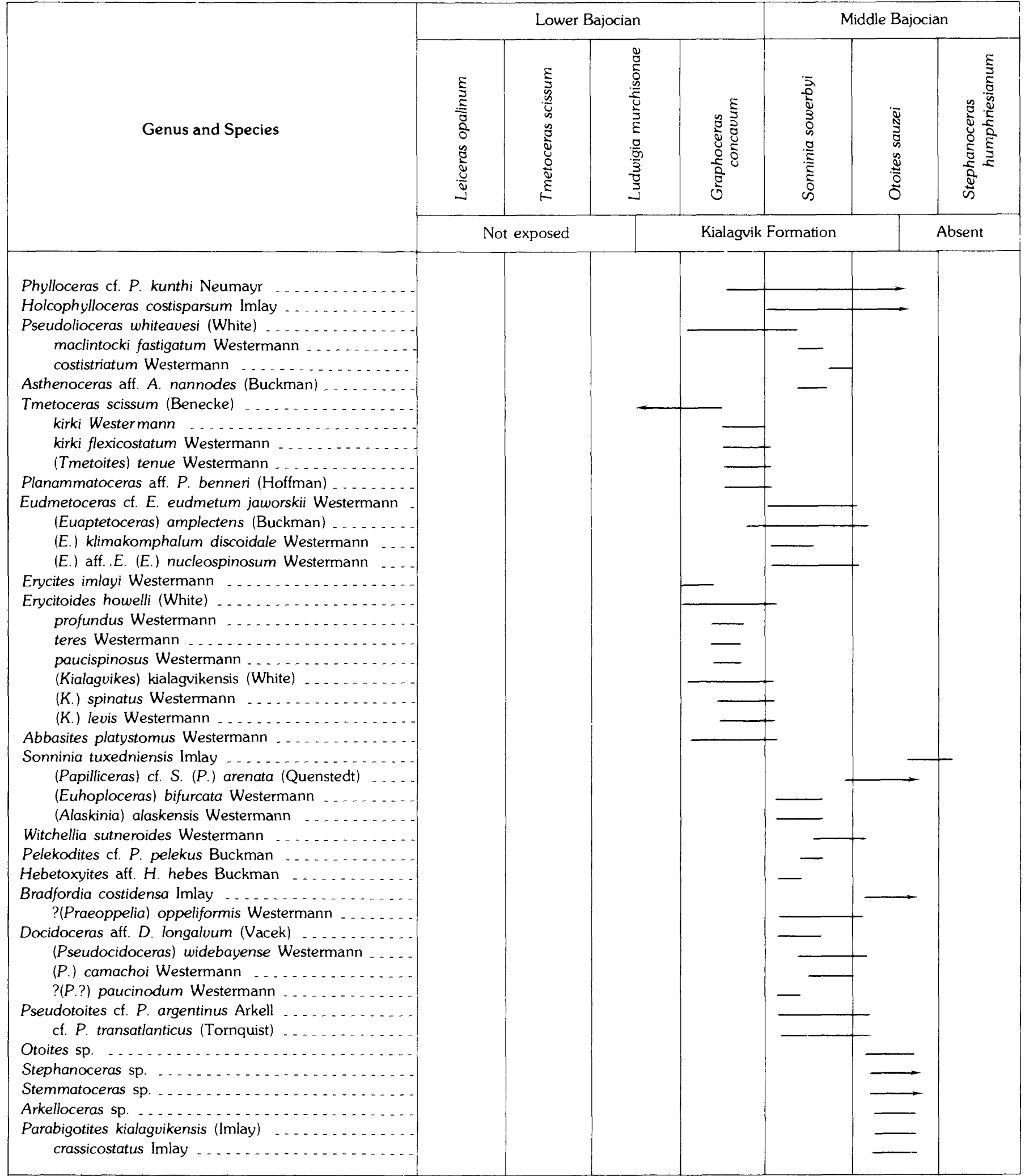

FIGURE 14.-Stratigraphic and chronologic correlations of some early and middle Bajocian ammonites present near Wide Bay on the Alaska Peninsula. 


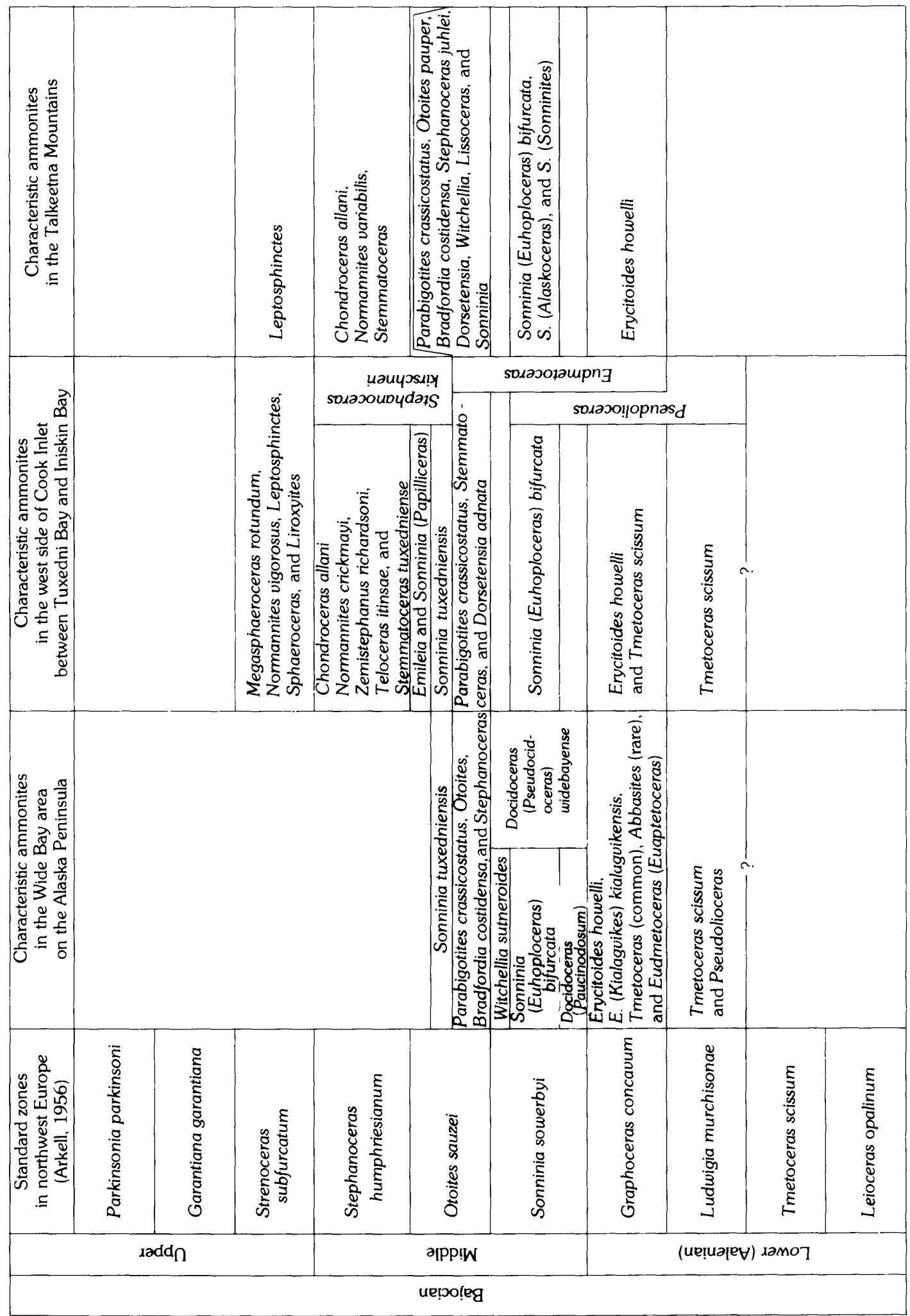

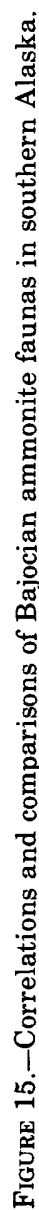


area west of Cook Inlet the species $C$. costidensus is associated with the Bathonian genera Siemeraldkira.

\section{TALKEETNA MOUNTAINS}

In the Nelchina area of the Talkeetna Mountains, ammonites of latest early Bajocian to early late Bajocian ages have been found in the Tuxedni Group (figs. $8,12,15)$. The latest early Bajocian zone of Graphoceras: concarum is represented by one specimen of Erycitrides hourlli (White) obtained as float from the basal $99 \mathrm{ft}(30 \mathrm{~m})$ of sandstone at Sheep Creek (USGS Mesozoic loc. 24135). The next younger zone of Somninia sorcerby is represented by Sonminia (Euhoploceras) bifurcuta Westermann obtained from the upper part of the same sandstone (USGS Mesozoic loc. 26723). The next younger zone of Otoitessauzei is represented in gray siltstone by Parabigotites crassicostatus Imlay (USGS Mesozoic locs. 24113 and 27577), by Bradfordia costidensa Imlay (USGS Mesozoic locs. 31728 , 24113, 24215, and 25345), by Otoites (USGS Mesozoic loc. 24113), and by Stephanoceras juhlei Imlay (USGS Mesozoic locs. 24113 and 24120). The next younger zone of Stephanocerashumphriesianum is represented in gray siltstone by Normannites rariabilis Imlay (USGS Mesozoic loc. 8567), Stemmatoceras (USGS Mesozoic loc. 30280). Chondroceras (USGS Mesozoic locs. 8567, 30280, 30594), and Leptosphinctes (USGS Mesozoic loc. 8567). Above follows reddish-gray siltstone that contains ammonites of early late Bajocian age, such as Megasphaeroceras, Sphaeroceras, and Cadomites, in association with Normam ites and Stemmatoceras (Imlay, 1952, p. 978, chart 8C opposite p. 998; Imlay, 1982, p. 1, 7-11).

Among the fossil collections listed, only those from USGS Mesozoic localities 24175 and 26723 are definitely from the lower sandstone unit of the Tuxedni Group. The others are from the upper siltstone unit, with the possible exceptions of USGS Mesozoic localities 27577,24113 , and 31728 . As the fossils at the last two localities are on landslide scars and the word "sandstone" is not used in their locality descriptions, the fossils could be from the upper siltstone unit.

In the Boulder Creek area of the Talkeetna Mountains an incomplete Bajocian sequence about $550 \mathrm{ft}$ $(168 \mathrm{~m})$ thick was measured on a divide at the head of a tributary of Boulder Creek and $6 \mathrm{mi}(9.6 \mathrm{~km}) \mathrm{N} .20^{\circ} \mathrm{E}$. of the junction of that tributary with East Boulder Creek (Imlay, 1980, fig. 3). That incomplete sequence, representing the upper part of the Tuxedni Group, contains ammonites ranging in age from middle middle Bajocian to early late Bajocian. From the uppermost $30 \mathrm{ft}(9 \mathrm{~m})$ of orange-gray siltstone was collected the ammonite Megasphaeroceras of early late Bajocian age. From 69 to $133 \mathrm{ft}$ ( 21 to $44 \mathrm{~m}$ ) lower in the sequence at USGS Mesozoic loc. 30281 was collected a specimen of Witchellia, which genus in Europe ranges through most of the zone of Somnimia somerbyri and all of the zone of Otoites sanzei.

Elsewhere in the Boulder Creek area the middle Bajocian zone of Otoites sauze $i$ is represented at USGS Mesozoic loc. 30582 by an occurrence of Somminia turedniensis Imlay, which west of Cook Inlet occurs in the upper part of the Red Glacier Formation. In addition, the zone of Stephanoceras humphriesianum is represented at USGS Mesozoic locs. 30594 and 8567 by Chondroceras allani (McLearn), which west of Cook Inlet occurs in the Fitz Creek Siltstone and in the overlying Cynthia Falls Sandstone. Furthermore, the association of that taxon with Normannites rariabilis Imlay and Leptosphinctes erolutus. Imlay at USGS Mesozoic loc. 8567 is good evidence for correlation with only the upper part of the zone of Stephanoceras humphriesianum.

The ages of the early and middle Bajocian ammonites that have been found in the Talkeetna Mountains are shown herein on figures 12 and 15 . Concerning the taxa listed on figure 12 , the following name changes should be noted:

1. Planammatoceras aff. P. berneri (Hoffman) was originally described as Sominia cf. S. patella Waagen by Imlay (1964, p. B33, pl. 3, figs. 2-4), but was revised by Westermann (1969, p. 24).

2. Eudmetoceras (Euaptetoceras) amplectens Buckman was originally described as Witchellia? aguilonia Imlay (1964, p. B35, pl. 4, figs. 1-4 fig. 9 , pl. 5, figs. 4, 7-9), but was revised by Westermann (written commun., 1964).

3. Sonninites cf. S. simulans Buckman was originally described as Witchellia cf. W. laeviuscula (J. de C. Sowerby) by Imlay (1964, p. B35, pl. 7, figs. 1-5).

4. Sominia (Euhoploceras) bifurcata Westermann was originally described as Somminia? n. sp. undet. by Imlay (1964, p. B33, pl. 4, figs. 5, 6, 10-12), but was revised by Westermann (1969, p. 94).

5. Sonninia (Alaskinia) cf. S. (A.) alaskensis Westermann was originally described as Sonminia cf. $S$. nodata Buckman by Imlay (1964, p. B33, pl. 2, figs. 1, 2), but was revised by Westermann (1969, p. 24,103$)$.

\section{WEST SIDE OF COOK INLET BETWEEN TUXEDNI BAY AND INISKIN BAY}

The uppermost lower Bajocian zone of Graphoceras concavum is fairly well represented on the south side of Tuxedni Bay (see figs. 9, 13, 15). North of Fossil Point 
it is represented by an association of Tmetoceras scissum (Benecke), Erycitoides hou'elli (White), and Pseudolioceras whiteavesi (White) at USGS Mesozoic localities 21233 and 21234, which occur from 150 to $480 \mathrm{ft}$ ( 46 to $146 \mathrm{~m}$ ) above the base of the Red Glacier Formation (see fig. 9). In the Lake Hickerson area, about 11 mi (17.6 km) southwest of Fossil Point, Tmetoceras scissum (Benecke) occurs at USGS Mesozoic locality 24335 from 900 to $1,100 \mathrm{ft}$ ( 273 to $334 \mathrm{~m}$ ) above the base of the Red Glacier Formation. Considerably farther south, on the Iniskin Peninsula, the ammonite Erycitoides (Kialagivikes) cf. E. (K.) kialagrikensis (White) (Mesozoic loc. $21244 \mathrm{~F}$ ) occurs in a well core drilled at a depth of 5,495-5,515 ft (1,675-1,681 $\mathrm{m})$ in Iniskin Bay Association well 1 (fig. 5). These ammonites in association favor an age assignment to the latest early Bajocian (Westermann, 1964, p. 345, 346, fig. 5; 1969 , p. 15, 18), although in southern Alaska Pseudolioceras ranges a little higher (Westermann, 1969, p. 17, 52-58) into beds characterized by Sominia (Euhoploceras) bifurcata Westermann, and Tmetoceras ranges throughout the lower Bajocian.

The ages of the middle Bajocian ammonites west of Cook Inlet have been discussed in previous publications (Imlay, 1964, p. 10-14; Imlay, 1973, p. 32, 33; Dettermann and Hartsock, 1966, p. 23, 28, 31, 34) and are shown herein in figures 13 and 15.

Concerning the taxa listed on figure 13. Dorsetensia adrata (Imlay) was originally described as Witchellia adrata Imlay (1964, p. B34, pl. 6, figs. 6-10), and Parabigotites kialagrikensis (Imlay), as Nomannites kialagviliensis Imlay (1964, p. B43, pl. 13, figs. 1-8, 10, $11,17)$.

\section{PUALE BAY AREA}

The Kialagvik Formation present near and on the beach along the northeast side of Puale Bay ranges in age from early Toarcian near its base to middle Bajocian near its top (figs. 8 and 10). These ages are based on the presence of (1) the early late Toarcian ammonite Haugia $30 \mathrm{ft}(9 \mathrm{~m})$ above the base of the formation (USGS Mesozoic loc. 19804), (2) the early Bajocian ammonites Tmetoceras and Erycitoides (Kialagrikes) $300-400 \mathrm{ft}(122-152 \mathrm{~m})$ above the base of the formation, or 900-950 ft (244-274 m) below the massive conglomerate (ROC locs. 1351, 1366, and 1370), (3) the middle Bajocian ammonites Bradfordia costidensa Imlay and Fontannesia cf. $F$. carinata Buckman about $200 \mathrm{ft}(61 \mathrm{~m})$ below the massive conglomerate (USGS Mesozoic loc. 21235), and (4) Dorsetensia? or Witchellia? of probable late middle Bajocian age near the top of the formation and about $500 \mathrm{ft}(152 \mathrm{~m})$ above the massive conglomerate (Imlay and Detterman, 1977, p. 609-611).

\section{WIDE BAY AREA}

The ammonites found in the Kialagvik Formation in the Wide Bay area can be grouped into at least four and perhaps five faunal subdivisions, or zonules, which from the base up include (1) Tmetoceras scissum, (2) Erycitoides howelli, (3) Docidoceras (Pseudocidoceras) widebayense, (4) Parabigotites crassicostatus, and, possibly, (5) Sonninia tuxedniensis (figs. 8, 11,14 , and 15).

The Tmetoceras scissum zonule is represented $\mathrm{n}$ the lower $328 \mathrm{ft}(100 \mathrm{~m})$ of the Kialagvik Formation exposed on Short Creek only by Tmetoceras scissum (Benecke) and Pseudolioceras sp. Of these genera, Tmetoceras in Eurasia ranges from the zones of Leioceras opalinum to Graphoceras concaum, inclusive. Pseudolioceras ranges from the Hildoceras bifrons zone in the upper Toarcian to the Sominia sowerbyi zone in the lower Bajocian. As Tmetoceras scissum (Benecke) in southern Alaska occurs only a little below the beds characterized by Erycitoides howell, it probably is equivalent in age to the zones of Luduigia murchisonae and Graphoceras concaum of northwest Europe.

The zonule of Erycitoides howell $i$ is characterized throughout by many occurrences of $E$. howelli White, E. (Kialagrikes) kialagrikensis(White), and Pseudolioceras whiteavesi (White), and by rare occurrences of Abbasites platystomus Westermann and Eudmetoceras (Euaptetaoceras) amplectens Buckman. Erycitoides howell $i$ is associated in the lower part of its range with rare occurrences of Erycites imlayi Westermann and some occurrences of Tmetoceras; in only the middle part by many occurrences of Erycitoides profundus Westermann and $E$. teres Westermann and a few occurrences of $E$. paucispinosus Westermann; in the middle to upper parts by $E$. (Kialagivies) spinatus Westermann; and in only the upper part by a few occurrences of Eudmetoceras cf. E. eudmetum jau'orskii Westermann, E. nuleospinosum Westermann, Tmetoceras kirki Westermann, T. kirki flexicostatum Westermann, and T. (Tmetoites) temue Westermann (Westermann, 1964, p. 345-352, figs. 3 and 5).

Based on these stratigraphic occurrences and on an abundance of well-preserved ammonites, the faunal subdivision characterized by $E$. howell $i$ was raised by Westermann (1964, p. 345-352, fig. 3$)$ to the rank of a zone and was divided into three subzones or zonules. Of these, the lower zonule is characterized by an abundance of E. howelli and by some Tmetoceras; the middle zonule, by Erycitoides profundus and E. teres; and the upper zonule, by Tmetoceras temue and T. flexicostatum. This division is probably valid, but needs to be checked by more field work. Furthermore, the name Erycitoides howelli cannot be applied to both a zone 
and a subzone, as was done by Westermann (1964, p. 345 ).

The beds characterized by these ammonites are correlated by Westermann (1964, p. 346) with the upper part of the lower Bajocian of Europe and, probably, with the zone of Graphoceras concaum, as is shown by the presence of Tmetoceras, which is not known above the concaurum zone in Europe, and of Eudmetoceras (Euaptetoceras), a subgenus that in Europe ranges from the middle of the Ludwigia murchinsonae zone into the lower fourth of the Somminia sowerbyi zone (see Imlay, 1973, p. 19, 31).

The Docidoceras (Pseudocidoceras) widebayense zonule, identified to date only on the southeast side of Wide Bay, is characterized throughout its lower $372 \mathrm{ft}$ $(114 \mathrm{~m})$ by an association of the following ammonite species:

Holcophylloceras costisparsum Imlay

Pseudolioceras fastigatum Westermann

P. maclintocki (Haughton)

P. costistriatum Westermann

Asthenoceras cf. A. namodes Buckman

Planammatoceras aff. P. benneri Hoffman

Sonninia (Euhoploceras) bifurcata Westermann

S. (Alaskinia) alaskensis Westermann

Witchellia sutneroides Westermann

Fontannesia intermedia Imlay

Praeoppelia oppeliformis Westermann

Docidoceras (Psendocidoceras) widebayense Westermann

cf. D. (P.) widebayense Westermann

D. (P.) camachoi Westermann

D.? (P.?) pauchinodosum Westermann

Eudmetoceras (Euaptetoceras) discoidale Westermann Pseudotoites cf. P. argentinus Arkell

P. P. transatlanticus (Tornquist)

The beds characterized by these ammonites were correlated by Westermann (1969, p. 20-22, 26) with the European zone of Sonninia sowerbyi based on the association of the taxa Pseudolioceras, Somminia (Euhoploceras), Witchellia, and Docidoceras and on the absence of such taxa as Chondroceras, Normannites, and Stemmatoceras (Imlay, 1973, p. 19, 21, 31).

The Parabigotites crassicostatus zonule is characterized throughout by an association of the following taxa:

Phylloceras cf. P. kunthi Neumayr

Holcophylloceras costisparsum Imlay

Eudmetoceras amplectens Buckman

Sonnina (Papilliceras) cf. S. (P.) arenata (Quenstedt)

Dorsetensia adnata (Imlay)

Bradfordia costidensa Imlay

Otoites cf. O. contractus (J. de C. Sowerby)
Stephanoceras (Skirroceras) ef. S. (S.) leptogyrale Buckman

Stemmatoceras sp.

Arkelloceras sp.

Parabigotites kialagvikensis (Imlay)

$P$. crassicostatus Imlay

$P$. cf. $P$. crassicostatus Imlay

The Parabigotites crassicostatus zonule is characterized by many occurrences of Eudmetoceras amplectens Buckman, Bradfordia costidensa Imlay, Parabigotites crassicostatus Imlay, and P. kialagvikensis (Imlay). Among the other taxa present, Sonninia (Papilliceras) has been found at three localities and the other genera at only one or two localities.

The ammonite zonule characterized by Parabigotites crassicostatus Imlay and Bradfordia costidensa Imlay has been found elsewhere in southern Alaska on the west side of Cook Inlet and in the Talkeetna Mountains. West of Cook Inlet those taxa occur in the upper part of the Red Glacier Formation at stratigraphic positions ranging from 252 to $654 \mathrm{ft}$ ( 77 to $214 \mathrm{~m}$ ) below its top (Imlay, 1964, p. B10-B12). In both areas the beds containing those ammonites have been correlated with the lower to middle parts of the zone of Otoites sauzei by the presence of such genera as Sonninia. Dorsetensia, and Lissoceras and by their occurrence below such ammonites as Normannites and Chondroceras.

The highest beds in the Kialagvik Formation above those containing Parabigotites are dated by the presence of Inoceramus lucifer Eichwald as being not younger than the zone of Otoites sauzei in Europe. That correlation is based on the fact that west of Cook Inlet, I. lucifer ranges through the Red Glacier Formation into the Gaikema Sandstone but no higher; and that the Gaikema Sandstone on the basis of ammonites is correlated with the upper part of the zone of Otoites sauzei (Imlay, 1964, p. B7, B12).

The highest beds in the Kialagvik Formation could be dated also by the presence of one specimen of Sonninia tuxedniensis Imlay, collected at the southwest end of Wide Bay from a sandstone unit exposed on a creek that enters the bay from the northwest about 1 mi north of Alai Creek (USGS Mesozoic loc. 10809). The same species of Somninia has been found elsewhere in southern Alaska west of Cook Inlet and also in the Talkeetna Mountains above beds containing Parabigotites. West of Cook Inlet in the Tuxedni Bay area it has been collected in place from 100 to $230 \mathrm{ft}(30.5$ to $70 \mathrm{~m})$ below the top of the Red Glacier Formation and is possibly represented $562 \mathrm{ft}(172 \mathrm{~m})$ below the top of the Red Glacier Formation (Imlay, 1964, p. B11). In the Tuxedni Bay area it has also been reported from the upper fourth of the Fitz Creek Siltstone on the basis of 
four specimens from two localities. Collections from one of these localities (USGS Mesozoic loc. 2999) are definitely float and from the other locality (USGS Mesozoic loc. 3000) include one specimen that appears to be worn and could be float (Imlay, 1964, p. B11, B13, B33). Evidently both stratigraphic and faunal evidence favors correlation of the highest beds in the Kialagvik Formation above the Parabigotites crassicostatus zonule with the highest few hundred feet of the Red Glacier Formation, which itself is correlated with the upper part of the zone of Otoites sauzei (Imlay, 1964, p. B7, B12; 1973, p. 10, 32).

The Kialagvik Formation is definitely represented in surface exposures at Wide Bay by one fairly well preserved specimen (see pl. 1, figs. 5, 6) of Hammatoceras of latest Toarcian age and by several float fragments of Erycitoides of late early Bajocian age(USGS Mesozoic loc. 10806). Those genera, judging by the faunal sequence at Puale Bay, are separated stratigraphically by beds at least $300 \mathrm{ft}(91 \mathrm{~m})$ thick. Their association at USGS Mesozoic loc. 10806 could be related to the presence of a fault that is uplifted on its south side and has possibly brought rocks of late Toarcian age to the surface. Their association could also be related to erosion of beds of late Toarcian age at Wide Bay during times when sea level was appreciably lower than it is today, such as occurred in Alaska during major glacial advances (Karlstrom, 1964, pl. 7) of Late Tertiary time.

\section{AMMONITE FAUNAL SETTING}

The early and middle Bajocian ammonites found in southern Alaska belong mostly to 20 genera that are common in Europe and occur nearly worldwide, except possibly in the Arctic region. Ammonite genera or subgenera that are characteristic of the Pacific region include Alaskinia, Pseudotoites. Praeoppelia, Arkelloceras, Parabigotites, Pseudocidoceras, and probably Erycitoides. The faunal succession in southern Alaska differs from that in Europe by the absence of any genera representing the Graphoceratidae.

\section{GEOGRAPHIC DISTRIBUTION}

Early and middle Bajocian ammonites have been found at many localities in southern Alaska, as described by the writer in 1964 and by Gerd Westermann in 1964 and 1969. Collections made subsequently in the Talkeetna and Wrangell Mountains have provided much new locality data, as shown in detail in table 2 .

In contrast, the region west of Cook Inlet between Tuxedni Bay and Iniskin Bay has furnished very few fossil collections since the middle Bajocian ammonites of that area were described by the writer in 1964
(USGS Prof. Paper 418-B). As the locality descriptions concerning those ammonites are readily available to the reader (Imlay, 1964, p. B22-B29), only those localities in that area that have furnished early Bajocian ammonites are described herein (table 3 , in part). The few ammonites found at Puale Bay are also listed in table 3. The many ammonites found near Wide Bay are listed in table 4 . The geographic location and stratigraphic positions of all the fossil localities thus listed are described herein in table 5 . The geographic postions of most of those localities are shown also, in figures 2-7.

\section{SYSTEMATIC DESCRIPTIONS}

\author{
Family Hildoceratidae Hyatt, 1867 \\ Genus Pseudolioceras Buckman, 1889 \\ Pseudolioceras cf. P. whiteavesi (White) \\ Plate 2, figure 11
}

cf. Ammonites (Amaltheus) whitearesi White, 1889. U.S. Geol. Survey Bull. 51. p. 69, pl. 13, figs. 1-5.

cf. Pseudolioceras mclintocki wh itearesi (White), Westermann, 1964, Bulls. American Paleontology, v. 47, no. 216, p. 421-425, pl. 68, fig. 2, pl. 69, figs. 1-6, pl. 70, figs. 1-4, pl. 71, figs. 1-2, text figs. 30-31.

Two laterally crushed, weathered specimens resemble Pseudolioceras mclintocki whiteavesi (White) in shape, coiling, strongly falcoid ribs, a fairly high keel, and the presence in one specimen of a slightly raised umbilical edge.

Figured specimen.-USNM 336000.

Occurrence.-Red Glacier Formation, silty sandstone on shoreline overlying Lower Jurassic volcanic rocks of the Talkeetna Formation at USGS Mesozoic loc. 29341. In SE cor. NE $1 / 4 \mathrm{SW}^{1 / 4}$ sec. 15, T. 1 N., R. 20 W., Kenai (A-8) quad., on southwest side of Tuxedni Bay, west of Cook Inlet.

\section{Genus Asthenoceras Buckman, 1899}

Asthenoceras cf. A. delicatum Imlay

Plate 1, figures 1, 2

cf. Asthenoceras sp. aff. A. nannodes Buckman, Westermann, 1969 , p. 61 , pl. 14, figs. 1-7.

cf. Asthenoceras delicatum Imlay, 1973, p. 55, pl. 3, figs. 1-32, pl. 4, figs. 3-6.

The genus Asthenoceras is represented at USGS Mesozoic loc. 19862 in the Wide Bay area by four specimens that were collected at or near the place (WA10) where Asthenoceras was collected by Westermann (1969, p. 61, pl. 14, figs. 1-7). The specimens in hand, however, differ from those described by Westermann by having appreciably coarser ribbing that is comparable with that on some specimens of Asthenoceras delicatum Imlay (1973, pl. 3, figs. 1, 4-11) from Oregon. 
TABLE 2.-Geographic distribution of early and middle Bajocian ammonites in the Wrangell and Talkeetna Mountains

\begin{tabular}{|c|c|c|c|c|c|c|c|c|c|c|c|c|c|c|c|c|c|c|c|c|c|c|c|c|c|c|c|}
\hline \multirow{4}{*}{ Genus and Species } & 点 & \multicolumn{26}{|c|}{ Talkeetna Mountains } \\
\hline & 3 & \multicolumn{21}{|c|}{ Nelchina area } & \multicolumn{5}{|c|}{$\begin{array}{c}\text { Boulder Creek } \\
\text { area }\end{array}$} \\
\hline & 1 & 2 & 3 & 4 & 5 & 6 & 7 & 7 & 8 & 9 & 9 & 10 & & 11 & 12 & 13 & & 14 & & 15 & & 16 & 17 & 7 & $18 \mid 1$ & 19 & 20 \\
\hline & 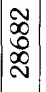 & $\begin{array}{l}\hat{N} \\
\mathfrak{n} \\
\mathfrak{N}\end{array}$ & $\mid \begin{array}{l}m \\
\stackrel{n}{\vec{J}}\end{array}$ & $\mid \begin{array}{c}\infty \\
\stackrel{N}{N} \\
\vec{m}\end{array}$ & 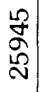 & $\mid \begin{array}{l}\underset{N}{N} \\
\stackrel{2}{N}\end{array}$ & 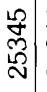 & 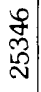 & $\begin{array}{c}0 \\
\stackrel{0}{2} \\
\stackrel{N}{N}\end{array}$ & 趈 & 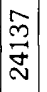 & $\begin{array}{l}\frac{10}{\sim} \\
\stackrel{\sim}{\mathcal{N}}\end{array}$ & 蛋 & $\begin{array}{l}\stackrel{m}{\sim} \\
\stackrel{\sim}{\sim}\end{array}$ & 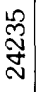 & $\underset{\mathrm{N}}{\stackrel{g}{\mathrm{~J}}}$ & $\begin{array}{l}\infty \\
\infty \\
\infty \\
\infty \\
\infty\end{array}$ & 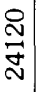 & 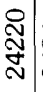 & $\begin{array}{l}\circ \\
\text { o̊ } \\
\text { లె }\end{array}$ & 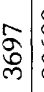 & $\begin{array}{l}8 \\
8 \\
8 \\
\text { ' }\end{array}$ & 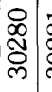 & 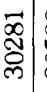 & & $\begin{array}{l}\hat{0} \\
\infty \\
\infty\end{array}$ & \\
\hline & & & & & & & & & & & & & & & & & & & & & & & & & & & \\
\hline Phylloceras cf. kunthi Neumayr . . . . . & & & $\mathbf{x}$ & & & & & & & & & & & & & & & & & & & & & & & & \\
\hline Partschiceras sp. & & & $\mathbf{x}$ & & & & & & & & & & & & & & & & & $\mathbf{x}$ & $\mathbf{x}$ & & & & & $\mathbf{X}$ & \\
\hline Calliphylloceras sp. & & & & & & & & & & & & & & & & & & & & & & $\mathbf{X}$ & & & & $\bar{x}$ & \\
\hline Holcophylloceras costisparsum Imlay & & & $\mathbf{x}$ & & & & & & & & & & & & & & & & & & & $\underline{\mathbf{X}}$ & & & & & \\
\hline sp. $\ldots \ldots \ldots \ldots$ & & & & & & & & & $\mathbf{x}$ & & & & & & & & & & & & & & & & & $\mathbf{X}$ & \\
\hline Lytoceras cf. L. eudisianum d'Orbigny & & & $\mathbf{x}$ & & & & & & & & & & & & & & & & $\mathbf{X}$ & & & & & & & $\mathbf{X}$ & \\
\hline sp. $\ldots \ldots \ldots$ & & & & & & & & & & & & $\mathbf{x}$ & & & & & & $\mathbf{X}$ & $\bar{x}$ & & & & & & & & \\
\hline Asthenoceras of A delicatum Imlay .... & & & & & & & & & & & $\mathbf{x}$ & & & & & & & & & & & & & & & & \\
\hline Pleydellia? sp. $\ldots \ldots \ldots \ldots \ldots$ & & & & & & & & & & & & & & & & $\mathbf{x}$ & & & & & & & & & & & \\
\hline Erycitoides howelli (White) . . . . . . . & & & & & & & & & & & & & & & $\underline{X}$ & & & & & & & & & & & & \\
\hline Planammatoceras of $P$. benneri (Hoffman) . . . . . . . & & & & & & & & & & & & & & & & & & $\mathbf{x}$ & & & $\mathbf{X}$ & & & & & & \\
\hline Eudmetoceras (Euaptetoceras) amplectens Buckman.... & & & $\mathbf{x}$ & $\mathbf{X}$ & & & & & & & & & & & & & & & & & & & & & & & \\
\hline Sonninia tuxedniensis Imlay $\ldots \ldots \ldots$ & & & & & & & & & & & & & & & & & & & & & & & & & $\underline{\mathbf{x}}$ & & \\
\hline cf. S. projectifer Buckman $\ldots \ldots \ldots$ & & & $\mathbf{x}$ & & & & & & & & & & & & & & & & & & & & & & & & \\
\hline sp. juv & & & & & & & & & & & & & & & & & & & & & $\mathbf{X}$ & & & & & & \\
\hline (Sonninites) cf. $S$ simulans Buckman .......... & & & $\mathbf{x}$ & & & & & & & & & & & & & & & $\mathbf{x}$ & & & & & & & & & \\
\hline (Euhoploceras) bifurcata Westermann .......... & & & & & & $\mathrm{X}$ & & & & & & & & & & & & $\rightarrow$ & & & & & & & & & \\
\hline (Alaskinia) cf. S. (A.) alaskensis Westermann .... & & & & & & & & & & & & & & & & & & $\mathbf{X}$ & & & & & & & & & \\
\hline (A.) $\mathrm{sp}$. & & & & & & & & & & & & & & & & & & & & & & $\mathbf{x}$ & & & & & \\
\hline (Papilliceras) cf. $S .(P$.$) espinazitenes (Tornquist) . .$ & & & $\mathbf{x}$ & & & & & & & & & & & & & & & & & & & & & & & & \\
\hline Dorsetensia cf. D. adnata (lmlay) . . . . . . . . . & & & $\mathbf{X}$ & & & & & & & & & $\mathbf{X}$ & & & & & & & & & & & & & & & \\
\hline Witchellia sp. & & & & & & & & & & & & & & & & & & & & & & $\mathbf{x}$ & & $\mathbf{X}$ & & & \\
\hline Fontannesia? sp. & & & 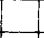 & & $\mathbf{x}$ & & & & & & & & & & & & & & & $\mathbf{x}$ & & & & & & & \\
\hline Lissoceras cf. L. semicostatum Buckman & & & & & & & & & & & & & & & & & & & & & & & & & $\mathbf{X}$ & & \\
\hline ? sp. & & & $\bar{x}$ & & & & & & & & & & & & & & & & & & & & & & & & \\
\hline Bradfordia costidensa lmlay $\ldots \ldots \ldots$ & & & $\mathbf{x}$ & $\mathbf{x}$ & & & $\mathbf{x}$ & & & & & $\mathbf{x}$ & & & & & & & & & & & & & & & \\
\hline ? caribouensis Imlay $\ldots \ldots \ldots \ldots$ & & & & & & & & & & & & & & & & & & & & $\mathbf{X}$ & & & & & & & \\
\hline Otoites cf. O. pauper Westermann & & & $x$ & & & & & & & & & & & & & & & & & & & & & & & & \\
\hline Emileia? sp. & & & $\mathbf{x}$ & & & & & & & $\mathbf{x}$ & & & & & & & & & & & & $\mathbf{X}$ & & & & & \\
\hline Normannites variabilis Imlay & $x$ & & & & & & & & & & & & & & & & & & & & & & & & & $\mathbf{x}$ & \\
\hline Teloceras cf. $T$. blagdeni (Sowerby) $\ldots \ldots \ldots \ldots$ & $x$ & & & & & & & & & & & & & & & & & & & & & & & & & & \\
\hline Stephanoceras obesum Imlay ..... & & & $\mathbf{x}$ & & & & & & & & & & & & & & & & & & & & & & & & \\
\hline (Skirroceras) juhlei Imlay & & & $x$ & & & & & & & & & & & & & & & $\mathbf{X}$ & & & & & & & & & \\
\hline (S.) nelchinanum lmlay $\ldots \ldots \ldots \ldots \ldots$ & & & $\mathbf{x}$ & & & & & & & & & & & & & & $\mathbf{x}$ & $\mathbf{x}$ & & & & $\mathbf{X}$ & & & & & \\
\hline (S.) sp. & & & & & & & & & & & & & & $\mathbf{x}$ & & & & $\mathbf{X}$ & & & $\mathbf{X}$ & & & & & & \\
\hline Stemmatoceras cf. S. pallisen (McLearn) .... & & & & & & & & & & & & & & & & & & & & & & & $\mathbf{x}$ & & & & \\
\hline sp. $\ldots \ldots \ldots \ldots \ldots$ & & & & & & & & $\mathbf{x}$ & & & & & & & & & & & & & & & & & & & \\
\hline Labyrinthoceras glabrum lmlay .. & & & & & & & & & & & & $\mathbf{X}$ & $\bar{x}$ & & & & & & & & & & & & & & \\
\hline Chondraceras allani (McLearn) - - & & & & & & & & & & & & & & & & & & & & & & & & & $\underline{\gamma}$ & & $\mathbf{x}$ \\
\hline cf. C. allani (McLeam) _. & & & & & & & & & & & & & & & & & & & & & & & $\underline{X}$ & & & & \\
\hline cf. C. marshalli (McLearn) . & & & & & & & & & & & & & & & & & & & & & & & & & & $\mathbf{X}$ & \\
\hline cf. C. colnetti (McLearn) - - & $\mathbf{X}$ & & & & & & & & & & & & & & & & & & & & & & & & & & \\
\hline Parabigotites crassicostatus lmlay . . . . . . . & & $\mathbf{x}$ & $x$ & & & & & & & & & & & & & & & & & & & & & & & & \\
\hline Leptosphinctes evolutus Imlay . . . . . . . & & & & & & & & & & & & & & & & & & & & & & & & & & $\mathbf{x}$ & \\
\hline & & & & & & & & & & & & & & & & & & & & & & & & & & & \\
\hline
\end{tabular}


TABLE 3.-Geographic distribution of some early and middle Bajocian ammonites west of Cook Inlet and northeast of Puale Bay on the Alaska Peninsula

[Number 21-23 are keyed to locality numbers on figure 12; number 24 to locality 24 on figure 13; and numbers $25-30$ to localities $25-30$ on figure 14]

\begin{tabular}{|c|c|c|c|c|c|c|c|c|c|c|c|}
\hline \multirow{4}{*}{ Genus and species } & \multicolumn{5}{|c|}{$\begin{array}{l}\text { West of } \\
\text { Cook Inlet }\end{array}$} & \multicolumn{6}{|c|}{$\begin{array}{c}\text { Northeast of } \\
\text { Puale Bay }\end{array}$} \\
\hline & \multicolumn{5}{|c|}{$\begin{array}{c}\text { Red Glacier } \\
\text { Formation }\end{array}$} & \multicolumn{6}{|c|}{$\begin{array}{l}\text { Kialagvik } \\
\text { Formation }\end{array}$} \\
\hline & \multicolumn{2}{|c|}{21} & \multicolumn{2}{|c|}{2223} & 24 & 25 & 26 & 27 & 28 & 29 & 30 \\
\hline & $\begin{array}{l}\stackrel{m}{N} \\
\stackrel{N}{N} \\
\stackrel{N}{N}\end{array}$ & 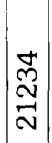 & 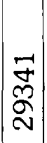 & 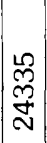 & $\begin{array}{c}\mathrm{U} \\
\mathcal{Z} \\
\mathbf{N} \\
\mathbf{N}\end{array}$ & 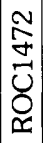 & $\begin{array}{c} \\
\tilde{N} \\
N \\
N\end{array}$ & 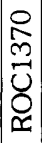 & $\begin{array}{c}0 \\
\text { } \\
\tilde{U} \\
0 \\
0\end{array}$ & $\begin{array}{l}\hat{\omega} \\
\text { m } \\
\tilde{U} \\
0 \\
\end{array}$ & $\begin{array}{l}o \\
\text { ñ } \\
u \\
0 \\
0\end{array}$ \\
\hline Pseudolioceras whiteavesi (White) . . . . . . . . . . & $\mathbf{X}$ & $X$ & & & & & & & & $X$ & $\mathbf{X}$ \\
\hline cf. $P$. whiteavesi (White) $\ldots \ldots \ldots$ & & & $\mathbf{X}$ & & & & & & & & \\
\hline Tmetoceras scissum (Benecke) & $\mathbf{X}$ & $X$ & & $\underline{X}$ & & & & $\underline{X}$ & $\mathbf{X}$ & & \\
\hline Erycitoides howelli (White) $\ldots \ldots \ldots$ & $\mathbf{X}$ & $\mathrm{X}$ & & & & & & & & & \\
\hline (Kialagvikes) cf. (K.) kialaguikensis (White) . . & & & & & $\underline{X}$ & & & & & $\mathbf{X}$ & $\bar{x}$ \\
\hline (K.) levis Westermann . . . . . . . . . . . . & & & & & & & & $\mathbf{X}$ & & & \\
\hline (K.) cf. K. spinatus Westermann & & & & & & & & & $\mathbf{X}$ & & \\
\hline Dorsetensia? sp. $\ldots \ldots \ldots$ & & & & & & $\mathbf{X}$ & & & & & \\
\hline Fontannnesia cf. $F$. cannata (Buckman) . . . . . . & & & & & & & $\mathrm{X}$ & & & & \\
\hline Bradfordia costidensa Imlay . . . . . . . . . . . . & & & & & & & $X$ & & & & \\
\hline & & & & & & & & & & & \\
\hline
\end{tabular}

Figured specimens.-USNM 335956 and 335957. Occurrence.-Kialagvik Formation at USGS Mesozoic loc. 19862 in SE cor. sec. 19, T. 33 S., R. 44 W., on the southeast side of Wide Bay, on the Alaska Peninsula.

Genus Tmetoceras Buckman, 1892

Tmetoceras scissum (Benecke)

Plate 1, figures 18,19

(For synonymy, see Westermann, 1964, Bulls. American Paleontology, v. 47 , no. 216 , p. 428,429 ).

This species is represented northwest of Cook Inlet by 21 specimens, of which most are small and fragmented. In shape and ribbing they fit very well with a detailed description made by Westermann (1964, p. 429-437, pl. 72, figs. 1a,b; 2a,b), and with a summary description by Imlay (1973, p. 59, pl. 2, figs. 1-6).

Hypotypes.-USNM 335965 and 335966.

Occurrence.-Red Glacier Formation, lower part, at USGS Mesozoic localities 21233, 21234, and 24335. Tmetoceras scissum (Benecke) is associated with Erycitoides howelli (White) at USGS Mesozoic locs. 21233 and 21234, southwest of Tuxedni Bay on the west side of Cook Inlet.

\section{Tmetoceras kirki flexicostatum Westermann}

Plate 1, figures 21-23

Tmetoceras kirki flexicostatum Westerman, 1964, Bulls. American Paleontology, v. 47, no. 216, p. 440, pl. 72, figs. 8-10.

This subspecies is characterized by having fine, densely spaced, flexuous ribs, whereas the species $T$. kirki has fairly strong, moderately spaced, nearly straight ribs, according to Westermann (1964, p. 438-440).

Type.-Hypotypes USNM 335968 and 335969.

Occurrence.-Kialagvik Formation, at USGS Mesozoic loc. 21254 on tributary of Short Creek on northwest side of Wide Bay, in north-central part of sec. 28 , T. 32 S., R. 44 W., Agashik (B-2) quad., Alaska.

\section{Family Hammatoceratidae Buckman, 1887 \\ Genus Hammatoceras Hyatt, 1867 \\ Hammatoceras sp. \\ Plate 1, figures 5, 6}

One ammonite collected from the Kialagvik Formation on the northwest side of Wide Bay at USGS esozoic loc. 10806 was identified by T. W. Stanton (Capps, 1921, p. 96) as "Hammatoceras" and compared with $H$. variabile (d'Orbigny). That species is now considered to be the genotype of Haugia, but the specimen from Wide Bay differs from Haugia by having (1) a stouter whorl section; (2) weaker tubercles that arise from the primary ribs at about one-fourth the height of the flanks; and (3) finer and denser secondary ribs on the middle and upper parts of the flanks. The ammonite from USGS Mesozoic loc. 10806 by contrast shows considerable resemblance to the genotype of $\mathrm{Ham}$ matoceras (Arkell and others, 1957, p. L267, fig. $307 c-e)$.

The occurrence of Hammatoceras at USGS Mesozoic loc. 10806 definitely favors an age as old as latest 
TABLE 4.-Geographic distribution of early and middle [Numbers 31-69 are keyed to locality numbers on figure 15 .

\begin{tabular}{|c|c|c|c|c|c|c|c|c|c|c|c|c|c|c|c|c|c|c|c|c|c|c|c|c|c|c|c|c|c|c|}
\hline \multirow{3}{*}{ Genus and Species } & \multicolumn{30}{|c|}{ Kralagvik Formation on northwest side of Wide Bay } \\
\hline & \multicolumn{2}{|c|}{31} & \multicolumn{2}{|c|}{32} & \multicolumn{4}{|c|}{33} & \multirow{2}{*}{\begin{tabular}{|l|}
34 \\
$\stackrel{0}{N}$ \\
$\frac{\mathrm{N}}{N}$ \\
\end{tabular}} & 35 & & 3 & 36 & & 3 & 7 & & 38 & & 39 & 40 & 41 & & 42 & & & 43 & & 44 & 45 \\
\hline & $\mid \begin{array}{l}0 \\
0 \\
2 \\
2 \\
2\end{array}$ & 占 & $\begin{array}{l}\hat{n} \\
2 \\
\sigma \\
=\end{array}$ & $\begin{array}{l}\hat{0} \\
2 \\
2\end{array}$ & 怘 & 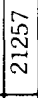 & 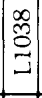 & 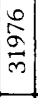 & & $\begin{array}{l}0 \\
2 \\
2 \\
\end{array}$ & $\mid$\begin{tabular}{l}
0 \\
2 \\
2 \\
2 \\
\hdashline
\end{tabular} & 芯 & $\left|\begin{array}{l}\infty \\
\stackrel{2}{2} \\
m\end{array}\right|$ & $\frac{\sigma}{\sigma}$ & $\mid$\begin{tabular}{c}
0 \\
\multirow{1}{*}{} \\
$\vdots$ \\
-
\end{tabular} & $\mid \begin{array}{l}8 \\
8 \\
8 \\
4\end{array}$ & 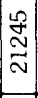 & $\begin{array}{l}\stackrel{f}{f} \\
\stackrel{2}{2}\end{array}$ & 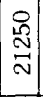 & 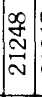 & $\underset{\sim}{\stackrel{N}{\mathbf{N}}}$ & $\begin{array}{l}0 \\
5 \\
2 \\
-\end{array}$ & 岕 & 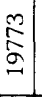 & 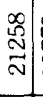 & $\begin{array}{l}0 \\
2 \\
2\end{array}$ & $\begin{array}{l}\infty \\
\sigma \\
\infty\end{array}$ & 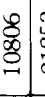 & 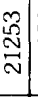 & \\
\hline Partschiceras ellipticum Westermann _... & & & & & & & & & & & & & & & & & & & & & & & & & & & & & & \\
\hline Holcophylloceras costisparsum Imlay $\ldots \ldots \ldots$ & & & & & & & & & & & & & & & & & & & & & & & & & & & & & & \\
\hline Pseudolioceras whiteavesi (White) & & & & & & & & & & & & $\mathrm{X}$ & $\mathbf{x}$ & & $\mathrm{X}$ & & $\mathbf{X}$ & $\mathbf{X}$ & & & & & & & & & & & & \\
\hline maclintocki fastigatum Westermann $\ldots \ldots \ldots$ & & & & & & & & & & & & & & & & & & & & & & & & & & & & & & \\
\hline costistriatum Westermann $\ldots \ldots \ldots$ & & & & & & & & & & & & & & & & & & & & & & & & & & & & & & \\
\hline Asthenoceras aff. A nannodes (Buckman) . . . . . . . . & & & & & & & & & & & & & & & & & & & & & & & & & & & & & & \\
\hline A cf. delicatum Imlay $\ldots \ldots$ & & & & & & & & & & & & & & & & & & & & & & & & & & & & & & \\
\hline Tmetoceras scissum (Benecke) & & & & & & & & & & & & $\mathrm{X}$ & $\mathbf{x}$ & & & & & & & $\mathbf{x}$ & $\mathbf{x}$ & & & & & & & & & \\
\hline kirki Westermann $\ldots \ldots$ & & & & & & & & & & & & $\mathrm{X}$ & & & & & & & & & & & & & & & & & & \\
\hline kirki flexicostatum Westermann & & & & & & & & & & & & $\mathrm{x}$ & & & & & & & & & & & & & & & & & & \\
\hline (Tmetoites) tenue Westermann $\ldots$ & & & & & & & & & & & & $\bar{x}$ & & & & & & & & & & & & & & & & & & \\
\hline Hammatoceras ? sp. & & & & & & & & & & & & & & & & & & & & & & & & & & & & $\mathbf{x}$ & & \\
\hline Planammatoceras aff $P$ benneri (Hoffman) $\ldots \ldots$ & & & & & & & & & & & & & & & & & & & & & & & & & & & & & & \\
\hline Eudmetoceras cf. E. eudmetum jaworskii Westermann $\ldots \ldots$ & & & & & & & & & & & & & & & & & & & & & & & & & & & & & & \\
\hline (Euaptetoceras) amplectens (Buckman) $\ldots \ldots$ & & & & & & & $\mathrm{x}$ & & & & & & & & & & & & & & & & & $\mathrm{x}$ & $\mathbf{X}$ & & & & & \\
\hline (E) klimakomohalum discoidale Westermann . . . . . . . & & & & & & & & & & & & & & & & & & & $\mathrm{X}$ & & & & & & & & & & & \\
\hline$(E)$ aff $E(E$.$) nucleospinosum Westermann \ldots \ldots \ldots$ & & & & & & & & & & & & & & & & & & & & & & & & & & & & & & \\
\hline Erycites imlayi Westermann $\ldots \ldots \ldots$ & & $x$ & & & & & & & & & & & & & & & & & & & & & & & & & & & & \\
\hline Erycitoides howelli (White) & $\mathbf{x}$ & & $\mathbf{X}$ & & & & & & & & & $\mathrm{x}$ & $\mathbf{x}$ & $\mathrm{X}$ & $\mathbf{X}$ & & & $\mathrm{X}$ & & & & & & & & & & & $\mathbf{X}$ & $\mathrm{X}$ \\
\hline cf $E$. howelli (White) & & & & & & & & & & & & & & & & & & & & $\mathbf{X}$ & & & & & & & $\mathrm{X}$ & $\mathrm{x}$ & & \\
\hline profundus Westermann & & & & & & & & & & & & & & & & $\bar{x}$ & & $\mathrm{x}$ & & & & & & & & & & & & \\
\hline teres Westermann $\ldots \ldots$ & & $\mathrm{X}$ & & & & & & & & & & & & & & $\mathrm{x}$ & $x$ & $\mathrm{X}$ & & & & & & & & & & & & \\
\hline paucispinosus Westermann & & & & & & & & & & & & & & & & $x$ & & & & & & & & & & & & & & \\
\hline (Kialaguikes) kialaguikensis (White) _. & $\mathrm{X}$ & & & $\mathrm{X}$ & & & & & & & $x$ & $\mathrm{X}$ & & $x$ & $\bar{x}$ & $\mathrm{x}$ & $\mathrm{X}$ & $\bar{x}$ & & & & & & & & & & & $\bar{x}$ & \\
\hline (K) spinatus Westermann $\ldots \ldots \ldots$ & & & & & & & & & & & & $x$ & & & $\mathbf{x}$ & & $x$ & $\bar{x}$ & & & & & & & & & & & & \\
\hline (K) levis Westermann $\ldots \ldots$ & & & & & & & & & & & & & & & $\mathbf{x}$ & $\mathrm{x}$ & & $\mathrm{X}$ & & & & & & & & & & & & \\
\hline Abbasites platystomus Westermann & & $x$ & & & & & & & & & $\mathbf{x}$ & & & & & & & & & & & & & & & & & & & \\
\hline Sonnınia tuxedniensis Imlay $\ldots \ldots \ldots \ldots$ & & & & & & & & & & & & & & & & & & & & & & & & & & & & & & \\
\hline (Papilliceras) cf. $S .(P$.$) arenata (Quenstedt) \ldots \ldots$ & & & & & & & & & & & & & & & & & & & & & & & & & & $x$ & & & & \\
\hline (Euhoploceras) bifurcata Westermann . . . . . . . . . . & & & & & & & & & & & & & & & & & & & & & & & & & & & & & & \\
\hline (Alaskinia) alaskensis Westermann _. & & & & & & & & & & & & & & & & & & & & & & & & & & & & & & \\
\hline Witchellia sutneroides Westermann & & & & & & & & & & & & & & & & & & & & & & & & & & & & & & \\
\hline cf. sutneroides Westermann & & & & & & & & & & & & & & & & & & & & & & & & & & & & & & \\
\hline Dorsetensia adnata (Imlay) $\ldots \ldots \ldots \ldots$ & & & & & & & $\mathrm{X}$ & & & & & & & & & & & & & & & & & & & & & & & \\
\hline Fontannesia cf. F. intermedia Imlay _. . . . . . . . . . . . & & & & & & & & & & & & & & & & & & & & & & & & & & & & & & \\
\hline Pelekodites cf. P. pelekus Buckman . . . . . . . . . . & & & & & & & & & & & & & & & & & & & & & & & & & & & & & & \\
\hline Hebetoxyites aff. $H$ hebes Buckman $\ldots \ldots \ldots$ & & & & & & & & & & & & & & & & & & & & & & & & & & & & & & \\
\hline Bradfordia constidensa Imlay & & & & & & $\mathbf{X}$ & & & $\mathrm{X}$ & $\mathrm{X}$ & & & & & & & & & & & & $\mathrm{X}$ & & $\mathrm{X}$ & & $\mathrm{x}$ & & & & \\
\hline Praeoppelia oppeliformis Westermann & & & & & & & & & & & & & & & & & & & & & & & & & & & & & & \\
\hline Docidoceras aff. D. longalvum (Vacek) $\ldots \ldots \ldots$ & & & & & & & & & & & & & & & & & & & & & & & & & & & & & & \\
\hline (Pseudocidoceras) widebayense Westermann $\ldots . . . . . .$. & & & & & & & & & & & & & & & & & & & & & & & & & & & & & & \\
\hline (P.) camachoi Westermann $\ldots \ldots \ldots$ & & & & & & & & & & & & & & & & & & & & & & & & & & & & & & \\
\hline (P.) cf $(P$.) camachoi Westermann $\ldots \ldots \ldots \ldots$ & & & & & & & & & & & & & & & & & & & & & & & & & & & & & & \\
\hline ?(P.) paucinodosum Westermann $\ldots \ldots \ldots$ & & & & & & & & & & & & & & & & & & & & & & & & & & & & & & \\
\hline Pseudotoites cf. $P$ argentinus Arkell $\ldots \ldots \ldots$ & & & & & & & & & & & & & & & & & & & & & & & & & & & & & & \\
\hline cf. $P$. transatlanticus (Tornquist) $\ldots \ldots$ & & & & & & & & & & & & & & & & & & & & & & & & & & & & & & \\
\hline Otoites $\mathrm{sp}$ & & & & & & $\mathrm{x}$ & & & & & & & & & & & & & & & & & & & & & & & & \\
\hline Stephanoceras (Skirroceras) ef $S$ (S.) teptogurale Buckman & & & & & & $\mathrm{x}$ & & & & & & & & & & & & & & & & & & & & & & & & \\
\hline Arkelloceras sp. & & & & & $\mathrm{X}$ & & & & & & & & & & & & & & & & & & & & & & & & & \\
\hline Parabigotites kialaguikensis (Imlay) $\ldots \ldots \ldots \ldots$ & & & & & & & & & $\mathrm{X}$ & & & & & & & & & & & & & & & $\bar{X}$ & $\bar{x}$ & & & & & \\
\hline crassicostatus Imlay ....... & & & & & & & & & & & & & & & & & & & & & & & \begin{tabular}{c|c}
$x$ \\
\end{tabular} & $\mathbf{x}$ & $\bar{x}$ & & & & & \\
\hline cf $P$. crassicostatus Imlay & & & & & & & & $\mathbf{x}$ & $\underline{X}$ & & & & & & & & & & & & & & & & & & & & & \\
\hline & & & & & & & & & & & & & & & & & & & & & & & & & & & & & & \\
\hline
\end{tabular}


Bajocian ammonites near Wide Bay on the Alaska Peninsula

Higher numbers are USGS Mesozoic locality numbers]

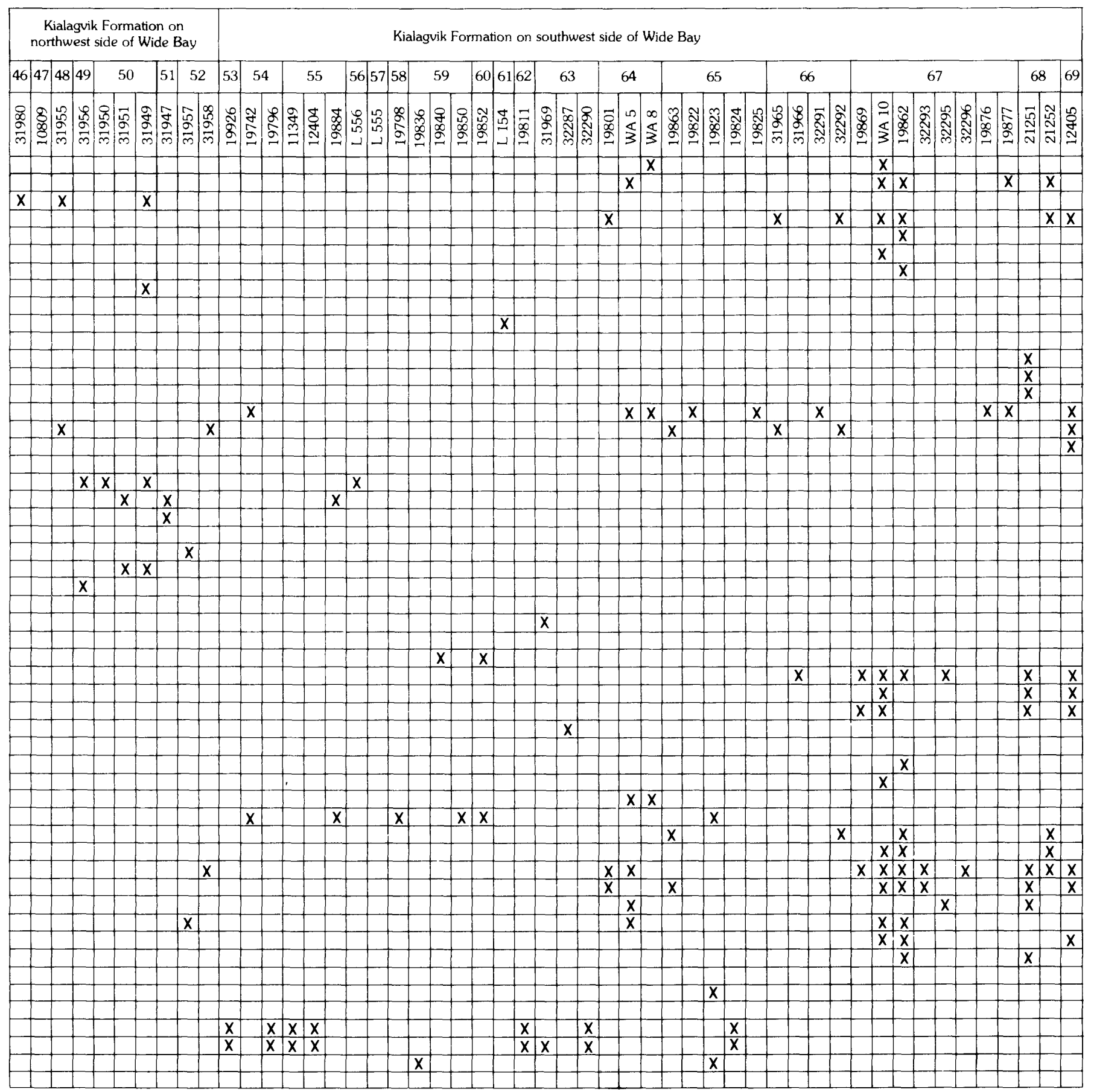


TABLE 5.-Descriptions of middle and lower Bajocian fossil localities in sonthern Alaska

\begin{tabular}{|c|c|c|c|}
\hline $\begin{array}{l}\text { Locality } \\
\text { No. }\end{array}$ & $\begin{array}{l}\text { USGS Mesozoic } \\
\text { locality }\end{array}$ & $\begin{array}{l}\text { Collectur's } \\
\text { field No. }\end{array}$ & Collectur, year of collection, description of locality. and stratigraphic assignment \\
\hline 1 & 28682 & $62 \mathrm{AMK} 53$ & $\begin{array}{l}\text { R. W. Imlay, 1962. Wrangell Mountains. McCarthy (C-5) quad. Near creek in center } \mathrm{SE}^{1 / 4} \\
\mathrm{NW}^{1}{ }_{4} \text { sec. } 20 \text {. T. } 3 \mathrm{~S} \text {.. R. } 16 \mathrm{E} \text {., Nizina Mountain Formation, mostly float. Probably from } \\
\text { the basal part of the formation. }\end{array}$ \\
\hline 2 & 27577 & & $\begin{array}{l}\text { Western Gulf Oil Co., } 1959 \text {. Talkeetna Mountains (A-1) quad., near Crooked Creek south of } \\
\text { Nelchina. lat. } 62^{\circ} 02^{\prime} 00^{\prime \prime} \text { N., long. } 147^{\circ} 18^{\prime} 00^{\prime \prime} \text { W., Tuxedni Group, lower part (probably } \\
\text { siltstone). }\end{array}$ \\
\hline 3 & 24113 & $52 \mathrm{AGz}-85$ & $\begin{array}{l}\text { Arthur Grantz, Richard Hoare, and R. W. Imlay, } 1952 \text {. Talkeetna Mountains (A-1) quad. } \\
\text { From a landslide scar } 1.63 \mathrm{mi}(2.6 \mathrm{~km}) \text { north of the mouth of Albert Creek. Tuxedni } \\
\text { Group } 200-250 \mathrm{ft}(61-76 \mathrm{~m}) \text { above base. }\end{array}$ \\
\hline$\ldots \ldots$. & 31728 & $79 \mathrm{AGz}-98$ & $\begin{array}{l}\text { Arthur Grantz, } 1979 \text {. Talkeetna Mountains (A-1) quad., lat. } 62^{\circ} 01^{\prime} 4^{\prime \prime} \text { N., long. } 147^{\circ} 17^{\prime} 36^{\prime \prime} \text { W., } \\
\text { Tuxedni Group (same locality as } 24113 \text { ). }\end{array}$ \\
\hline 5 & $25945 \ldots \ldots \ldots$ & $55 \mathrm{AGz}-245 \mathrm{a} \ldots$ & $\begin{array}{l}\text { Arthur Grantz, } 1955 \text {. Talkeetna Mountains (A-1) quad., lat. } 62^{\circ} 02^{\prime} 28^{\prime \prime} \text { N.. long. } 147^{\circ} 22^{\prime} 59^{\prime \prime} \text { W., } \\
\text { Tuxedni Group, upper half of lower sandstone. }\end{array}$ \\
\hline$\ldots . .$. & 26723 & $57 \mathrm{AGz} 43 \mathrm{~N}$ & $\begin{array}{l}\text { Arthur Grantz, } 1957 \text {. Talkeetna Mountains (A-1) quad., lat. } 62^{\circ} 02^{\prime} 00^{\prime \prime} \text { N., long. } 147^{\circ} 25^{\prime} 15^{\prime \prime} \text { W., } \\
\text { Tuxedni Group, upper half of basal sandstone. }\end{array}$ \\
\hline 7 & 25345 & $54 \mathrm{AFy} 28 \ldots \ldots$ & $\begin{array}{l}\text { L. F. Fay, } 1954 \text {. Talkeetna Mountains (A-2) quad., lat. } 62^{\circ} 00^{\prime} 46^{\prime \prime} \text { N., long. } 147^{\circ} 34^{\prime} 02^{1 / 2}{ }^{\prime \prime} \text { W., } \\
\text { Tuxedni Group, upper siltstone. }\end{array}$ \\
\hline 7 & 25346 & 54 A Fy 29 & $\begin{array}{l}\text { L. F. Fay, } 1954 \text {. Talkeetna Mountains (A-2) quad., lat. } 62^{\circ} 00^{\prime} 41^{\prime \prime} \text { N., long. } 147^{\circ} 34^{\prime} 16^{\prime \prime \prime}{ }^{\prime \prime} \text { W., } \\
\text { Tuxedni Group, upper siltstone. }\end{array}$ \\
\hline 8 & 24176 & $52 \mathrm{AHr} 51$ & $\begin{array}{l}\text { Richard Hoare, } 1952 \text {. Anchorage (D-2) quad.. Pass Creek, } 0.35 \mathrm{mi}(0.56 \mathrm{~km}) \text { above its mouth. } \\
\text { Tuxedni Group, basal sandstone, } 100-200 \mathrm{ft}(30-61 \mathrm{~m}) \text { above base. }\end{array}$ \\
\hline 9 & 25946 & $55 \mathrm{AGz} 309$ & $\begin{array}{l}\text { Arthur Grantz and W. H. Condon, } 1955 \text {. Anchorage (D-2) quad., lat. } 61^{\circ} 57^{\prime} 47^{\prime \prime} \text { N., long. } \\
147^{\circ} 24^{\prime} 21^{\prime \prime} \text { W., Tuxedni Group. } 200-300 \mathrm{ft}(61-91 \mathrm{~m}) \text { above base. }\end{array}$ \\
\hline$\ldots \ldots$. & 24137 & $52 \mathrm{AGz} 284$ & $\begin{array}{l}\text { Arthur Grantz, R. W. Imlay, and D. Hoare, } 1952 \text {. Anchorage (D-2) quad., } 0.53 \mathrm{mi}(0.9 \mathrm{~km}) \mathrm{S} \text {. } \\
74^{1 / \%} \text { E. of mouth of Pass Creek and } 0.16 \mathrm{~km} \text { south of USGS Mesozoic loc. } 25946 \text {. Tuxedni } \\
\text { Group, basal sandstone } 200-300 \mathrm{ft}(61-91 \mathrm{~m}) \text { above base. }\end{array}$ \\
\hline 10 & 24215 & $52 \mathrm{AGz} 182$ & $\begin{array}{l}\text { Richard Hoare and Arthur Grantz, 1952. Anchorage (D-2) quad., Alfred Creek, } 0.8 \mathrm{mi}(1.3 \mathrm{~km}) \\
\text { east of Papoose Creek. Tuxedni Group, upper siltstone. }\end{array}$ \\
\hline$\ldots \ldots$ & 25942 & $55 \mathrm{AGz} 163$ & $\begin{array}{l}\text { Arthur Grantz and W. H. Condon, } 1955 \text {. Anchorage (D-2) quad., lat. } 61^{\circ} 57^{\prime} 09^{\prime \prime} \text { N., long. } \\
147^{\circ} 27^{\prime} 56^{\prime \prime} \text { W.. Tuxedni Group. upper siltstone. }\end{array}$ \\
\hline 11 & 24134 & $52 \mathrm{AGz} 275$ & $\begin{array}{l}\text { Arthur Grantz, Richard Hoare, and R. W. Imlay. 1952. Anchorage (D-2) quad., } 2.63 \mathrm{mi}(4.2 \\
\mathrm{km} \text { ) N. } 51_{1 / 2}^{1 / 0} \text { E. of mouth of Sheep Creek. Tuxedni Group, base of upper siltstone. }\end{array}$ \\
\hline 12 & 24235 & $52 \mathrm{AGz} 240$. & $\begin{array}{l}\text { Arthur Grants, Richard Hoare, and R. W. Imlay, 1952. Anchorage (D-2) quad., Sheep Creek, } \\
2.20 \mathrm{mi}(3.32 \mathrm{~km}) \mathrm{N} .16^{1 / 2} \text { E. of its mouth. Tuxedni Group. float from the lower } 30.5 \mathrm{~m} \text { of } \\
\text { the basal sandstone. }\end{array}$ \\
\hline 13 & 24149 & $52 \mathrm{AGz} 233$ & $\begin{array}{l}\text { Arthur Grantz. Richard Hoare, and R. W. Imlay, } 1952 \text {. Anchorage (D-2) quad., } 3 \mathrm{mi}(4.8 \mathrm{~km}) \\
\text { N. } 9^{\circ} \text { E. of the mouth of Sheep Creek on a small west tributary. Tuxedni Group, float from } \\
\text { the lower } 100 \mathrm{ft}(30.5 \mathrm{~m}) \text { of the basal sandstone. }\end{array}$ \\
\hline 14 & 8585 & $13 \mathrm{AM} 36$ & $\begin{array}{l}\text { G. C. Martin, 1913. Anchorage (D-2) quad., north bank of Caribou Creek } 0.75 \mathrm{mi}(1.2 \mathrm{~km}) \text { east } \\
\text { of mouth of Billy Creek. Tuxedni Group, upper siltstone. }\end{array}$ \\
\hline$\ldots \ldots$. & 24120 & $52 \mathrm{AGz} 198$. & $\begin{array}{l}\text { Arthur Grantz, Richard Hoare, and R. W. Imlay, 1952. Anchorage (D-3) quad., Caribou Creek } \\
0.62 \mathrm{mi}(1 \mathrm{~km}) \text { east of Billy Creek. Tuxedni Group, upper siltstone. }\end{array}$ \\
\hline 14 & 24220 & $52 \mathrm{AGz} 215$ & $\begin{array}{l}\text { Arthur Grantz. Richard Hoare, and R. W. Imlay, 1952. Anchorage (D-2) quad., north side of } \\
\text { Caribou Creek, } 0.73 \mathrm{mi}(1.17 \mathrm{~km}) \text { east of mouth of Billy Creek. Tuxedni Group, upper silt- } \\
\text { stone. }\end{array}$ \\
\hline 15 & 3696 & $6 \mathrm{AK} 88 \mathrm{~A}$ & $\begin{array}{l}\text { Adolph Knopf, 1906. Anchorage (D-3) quad., at altitude of } 4.050 \mathrm{ft} \text {, on tributary of Caribou } \\
\text { Creek that joins main creek from south } 0.25 \mathrm{mi}(0.40 \mathrm{~km}) \text { above mouth of Billy Creek. } \\
\text { Tuxedni Group, upper siltstone. }\end{array}$ \\
\hline 15 & 3697 & $6 \mathrm{AK} 88 \mathrm{~B}$ & $\begin{array}{l}\text { Adolph Knopf, 1906. Anchorage (D-3) quad., boulder in stream bed at same location as Meso- } \\
\text { zoic loc. } 3696 \text {. }\end{array}$ \\
\hline 16 & 30600 & $74 \mathrm{APr} 60 \mathrm{~b}$ & $\begin{array}{l}\text { George Pflaker, } 1974 \text {. Anchorage (D-3) quad., } 1.5 \mathrm{mi} \mathrm{N} .45^{\circ} \mathrm{E} \text {. of VABM Chitna in sec. } 4 . \mathrm{T} .21 \\
\text { N., R. } 9 \text { E., elev. } 5,250 \mathrm{ft} \text {. Tuxedni Group, dark shale that contains a few sandstone beds } \\
\text { and is intruded by a basaltic dike. }\end{array}$ \\
\hline 17 & 30280 & $72 \mathrm{AD} 7-11 \# 6 \ldots$ & $\begin{array}{l}\text { R. L. Detterman, R. W. Imlay, and Don Hartman, } 1972 \text {. Anchorage (D-3) quad. From southern } \\
\text { part of divide north of peak (elev. } 5.900 \mathrm{ft}) \text { north of Boulder Creek, } 1.2 \mathrm{mi}(1.9 \mathrm{~km}) \mathrm{S} .35^{\circ} \\
\text { W. of VABM Snag. SE }{ }_{1 / 4} \text { sec. } 26 . \mathrm{T} .22 \mathrm{~N} \text {.. R. } 7 \mathrm{E} \text {., Tuxedni Group, upper part, from lower } \\
75 \mathrm{ft}(23 \mathrm{~m}) \text { of } 175 \mathrm{ft}(53 \mathrm{~m}) \text { of brown-to-gray siltstone that underlies } 80 \mathrm{ft}(24 \mathrm{~m}) \text { of vol- } \\
\text { canic graywacke. }\end{array}$ \\
\hline 17 & 30281 & 72AD7-12 & $\begin{array}{l}\text { R. L. Detterman, R. W. Imlay, and Don Hartman, } 1972 \text {. Anchorage (D-3) quad., } 1.1 \mathrm{mi}(1.8 \mathrm{~km}) \\
\text { S. } 38^{\circ} \text { W. of VABM Snag near center of sec. } 26 . \text { T. } 22 \text { N., R. } 7 \text { E., Tuxedni Group, sand- } \\
\text { stone, grit, and conglomerate with siltstone interbeds about } 250-300 \mathrm{ft}(76-91 \mathrm{~m}) \text { below } \\
\text { siltstone listed under USGS Mesozoic loc. } 30280 \text {. }\end{array}$ \\
\hline
\end{tabular}


TABLE 5.-Descriptions of middle and loner Bajocian fossil localities in southern Alaska-Contimned

\begin{tabular}{|c|c|c|c|}
\hline $\begin{array}{l}\text { Locality } \\
\text { No. }\end{array}$ & $\begin{array}{l}\text { USGS Mesozoic } \\
\text { locality }\end{array}$ & $\begin{array}{l}\text { Collector's } \\
\text { field No. }\end{array}$ & Collector, year of collection. description of locality, and stratigraphic assignment \\
\hline 18 & 30582 & 74AD7-95 & $\begin{array}{l}\text { R. L. Detterman, } 1974 \text {. Anchorage (D-3) quad.. on ridge south of tributary of Boulder Creek in } \\
\text { sec. } 4 \text {. T. } 21 \text { N.. R. } 7 \text { E.. } 0.88 \mathrm{mi}(1.4 \mathrm{~km}) \mathrm{S} .40^{\circ} \text { E. of VABM Suicide. Tuxedni Group, near } \\
\text { middle, from interbedded brown sandstone, siltstone, and siltstone and shale containing } \\
\text { limestone concretions. }\end{array}$ \\
\hline 19 & $8567 \ldots \ldots \ldots$ & $113 \mathrm{AM} 16$ & $\begin{array}{l}\text { G. C. Martin, R. M. Overbeck, and J. B. Mertie, Jr., 1913. Anchorage (D-4) quad., in north- } \\
\text { central part of NE } 1 / 4 \text { sec. 19. T. } 21 \text { N.. R. } 7 \text { D., Tuxedni Group. }\end{array}$ \\
\hline 20 & $30594 \ldots \ldots . .$. & 74ADT130A & $\begin{array}{l}\text { R. L. Detterman, 1974. Anchorage (D-4) quad. } \mathrm{SE}^{1 / 4} \mathrm{NE}^{1}{ }_{4} \text { sec. } 20 \text {. T. } 21 \mathrm{~N} ., \mathrm{R} .7 \mathrm{E} ., 2.8 \mathrm{mi}(4.48 \\
\mathrm{km}) \mathrm{N} .73^{\circ} \mathrm{E} \text {. of VABM Pudding, elev. } 5.400 \mathrm{ft} \text { on ridge west of Boulder Creek. Tuxedni } \\
\text { Group, high in sequence of dark-greenish sandstone bearing volcanic clasts. }\end{array}$ \\
\hline 21 & 21233 & 48AI77 & $\begin{array}{l}\text { R. W. Imlay and D. J. Miller, 1948. South side of Tuxedni Bay. West central part of } \mathrm{NW}^{1 / 4} \\
\text { SW } 1_{4} \text { sec. } 15, \text { T. } 1 \mathrm{~N} . \text {., R. } 21 \mathrm{~W} . \text { Kenai }(\mathrm{A}-8) \text { quad.. on creek entering Tuxedni Bay from } \\
\text { south } 2.25 \mathrm{mi}(3.6 \mathrm{~km}) \mathrm{N} .77^{\circ} \mathrm{W} \text {. of Fossil Point. Red Glacier Formation, } 380-480 \mathrm{ft} \\
(116-146 \mathrm{~m}) \text { above base and } 1,500 \mathrm{ft}(457 \mathrm{~m}) \text { below top in sandy siltstone interbedded with } \\
\text { sandstone. Location is indicated by number (830) on pl. } 3 \text { of U.S. Geol. Survey Prof. Paper } \\
512 .\end{array}$ \\
\hline $21 \ldots \ldots$ & 21234 & 48AI78 & $\begin{array}{l}\text { R. W. Imlay and D. J. Miller, 1948. South side of Tuxedni Bay. Float from same place and } \\
\text { probably from same bed as USGS Mesozoic loc. } 21233 \text {. Red Glacier Formation. }\end{array}$ \\
\hline 22 & $29341 \ldots \ldots . .$. & Ken 72 & $\begin{array}{l}\text { British Petroleum Exploration Co., 1962. South side of Tuxedni Bay, } \mathrm{SE} \text { cor. NE1/4, SW }{ }^{1_{4}} \text { sec. } \\
\text { 15, T. } 1 \text { N.. R. } 20 \text { W.. Kenai (A-8) quad. Red Glacier Formation, first exposure of silty } \\
\text { sandstone overlying Lower Jurassic volcanic rocks to the northwest. }\end{array}$ \\
\hline 23 & 24335 & 52AJU516A ........ & $\begin{array}{l}\text { R. W. Imlay, } 1952 . \text { On low divide north of Red Glacier, } 2.5 \mathrm{mi}(4 \mathrm{~km}) \text { west of Red Creek and } \\
5.2 \mathrm{mi}(8.3 \mathrm{~km}) \mathrm{N} .5^{\circ} \mathrm{W} \text {. of Blue Lake. North-central part } \mathrm{NE}^{1_{4}} \mathrm{NW}^{1_{4}} \text { sec. } 33 \text {. T. } 1 \mathrm{~S} ., \mathrm{R} .21 \\
\text { W.. Kenai }(\mathrm{A}-8) \text { quad. Red Glacier Formation, lower siltstone member, about } 900-1.000 \mathrm{ft} \\
(274-335 \mathrm{~m}) \text { above base and } 3.400-3.600 \mathrm{ft}(1.036-1.097 \mathrm{~m}) \text { below top. Location is indicated } \\
\text { by number }(\times 40) \text { on pl. } 3 \text { of U.S. Geol. Survey Prof. Paper } 512 \text {. }\end{array}$ \\
\hline 24 & $21244 \mathrm{~F}$ & 48AI32 & $\begin{array}{l}\text { R. W. Imlay, J. K. Hartsock, and D. J. Miller, } 1948 \text {. By Iniskin Peninsula on Fitz Creek near } \\
\text { Tonnie Creek. Iniskin Bay Assoc. well } 1 \text { in } \mathrm{SE}_{4}^{1} \text { sec. } 8 \text {. T. } 5 \mathrm{~S} ., \mathrm{R} .23 \mathrm{~W} \text {., Seward Meridian. } \\
\text { Red Glacier Formation, hard gray-to-black siltstone, at } 5,495-5,515 \mathrm{ft}(2,225-2,231 \mathrm{~m}) \\
\text { below top. Detterman and Hartsock, } 1966, \text { p. } 72,73 \text {, table } 4 \text { on p. } 24 \text {, and pl. } 4 \text {; location is } \\
\text { indicated by number }(\times 41) \text { on pl. } 3 \text {. }\end{array}$ \\
\hline 25 & ROC1472. & 1962 & $\begin{array}{l}\text { W. T. Rothwell and associates of the Richfield Oil Co. Collected about } 2.800 \mathrm{ft}(853 \mathrm{~m}) \mathrm{N} .50^{\circ} \\
\text { W. of VABM } 119 \text { Bay on northeast side of Puale Bay in the Karluk }(\mathrm{C}-4 \text { and C-5) quad., on } \\
\text { the Alaska Peninsula. Kialagvik Formation, near top, and about } 500 \mathrm{ft}(152 \mathrm{~m}) \text { above a } \\
\text { massive conglomerate. }\end{array}$ \\
\hline 26 & 21235 & $48 \mathrm{AI} 110$ & $\begin{array}{l}\text { Ralph Imlay, } 1948 \text {. Sea cliff on northeast side of Puale Bay, } 2.24 \mathrm{mi}(3.58 \mathrm{~km}) \mathrm{N} .19^{\circ} \mathrm{W} \text {. of } \\
\text { Cape Kekurnoi on the Alaska Peninsula. Kialagvik Formation, from a concretion in silt- } \\
\text { stone about } 200 \mathrm{ft}(61 \mathrm{~m}) \text { below base of massive conglomerate. }\end{array}$ \\
\hline 27 & ROC1370 .. & (2. & $\begin{array}{l}\text { Richfield Oil Co., } 1962 \text {. Southeast shore of Puale Bay, about } 2 \mathrm{mi}(3.2 \mathrm{~km}) \mathrm{N} .18 \%{ }^{\circ} \mathrm{W} \text {. of Cape } \\
\text { Kekurnoi on the Alaska Peninsula. Kialagvik Formation, about } 100 \mathrm{ft}(30.5 \mathrm{~m}) \text { below top } \\
\text { of ashy beds and about } 800 \mathrm{ft}(244 \mathrm{~m}) \text { below the base of a massive conglomerate. }\end{array}$ \\
\hline 28 & ROC 1366 & & $\begin{array}{l}\text { Geologists of the Richfield Oil Co., } 1962 \text {. Northeast shore of Puale Bay, about } 650 \mathrm{ft}(198 \mathrm{~m}) \mathrm{S} \text {. } \\
25^{\circ} \text { E. of VABM } 119 \text { Bay. Kialagvik Formation, about } 40 \mathrm{ft}(12 \mathrm{~m}) \text { below ROC loc. } 1370 .\end{array}$ \\
\hline 29 & ROC1351 & & $\begin{array}{l}\text { Geologists of the Richfield Oil Co.. } 1962 \text {. Northeast shore of Puale Bay, about } 1,250 \mathrm{ft}(381 \mathrm{~m}) \\
\text { S. } 25^{\circ} \text { E. of VABM } 119 \text { Bay. Kialagvik Formation, about } 900-950 \mathrm{ft}(274-290 \mathrm{~m}) \text { below } \\
\text { massive conglomerate. }\end{array}$ \\
\hline 30 & ROC1356.. & & Geologists of the Richfield Oil Co., 1962. Northeast side of Puale Bay, near locality ROC1351. \\
\hline 31 & 19766 & $44 \mathrm{AKmF} 36$ & $\begin{array}{l}\text { L. B. Kellum, } 1944 \text {, Float from base of cliffs. About } \text { mile south of mouth of Pass Creek and } \\
3.6 \mathrm{mi}(6 \mathrm{~km}) \mathrm{N} .45^{\circ} \mathrm{W} \text {. of west end of Hartman Island. Kialagvik Formation, about } 480 \mathrm{ft} \\
(146 \mathrm{~m}) \text { below top. }\end{array}$ \\
\hline 31 & 21246 & 48AI95 & $\begin{array}{l}\text { R. W. Imlay and D. J. Miller, } 1948 . \mathrm{SE}^{1 / 4} \mathrm{NW}_{1 / 4}^{1 / 4} \text { of sec. } 24 \text {, T. } 32 \mathrm{~S} . \text {., R. } 44 \mathrm{~W} \text {., sea cliff along } \\
\text { beach } 3.1 \mathrm{mi}(5 \mathrm{~km}) \mathrm{N} .50^{\circ} \mathrm{W} \text {. of west end of Hartman Island. About } 0.2 \mathrm{mi}(0.32 \mathrm{~km}) \\
\text { northeastward along a cliff composed of sandstone and siltstone. Kialagvik Formation, } \\
\text { about } 800 \mathrm{ft}(244 \mathrm{~m}) \text { below top. }\end{array}$ \\
\hline 32 & 19757 & $44 \mathrm{AKmF} 23$ & $\begin{array}{l}\text { L. B. Kellum and assistants, } 1944 \text {. Float at base of sea cliff between Pass Creek and Short } \\
\text { Creek northeast of small waterfall and } 0.5 \mathrm{mi}(0.2 \mathrm{~km}) \text { southwest of Pass Creek. SE } 1 / 4 \text { sec. } \\
\text { 23, T. } 32 \mathrm{~S} \text {., R. } 44 \mathrm{~W} \text {. Kialagvik Formation, } 880-995 \mathrm{ft}(268-303.5 \mathrm{~m}) \text { below top. }\end{array}$ \\
\hline 32 & 19767 & $44 \mathrm{AKm} 37$ & $\begin{array}{l}\text { L. R. Kellum, 1944. SE } 1 / 4 \text { sec. } 23 . \text { T. } 32 \text { S., R. } 44 \text { W., Kialagvik Formation, about 1,050 ft ( } 320 \\
\text { m) below top. }\end{array}$ \\
\hline 33 & 21255 & 48AI89 & $\begin{array}{l}\text { R. W. Imlay and D. F. Miller, 1948. Southwest bank of tributaries entering Short Creek about } \\
1 \mathrm{mi}(1.6 \mathrm{~km}) \text { northwest of beach. North-central part of SW1/4 sec. } 28 \text {. T. } 32 \mathrm{~S} \text {., R. } 44 \mathrm{~W} \text {. } \\
\text { Kialagvik Formation, from gray siltstone about } 400 \mathrm{ft}(122 \mathrm{~m}) \text { below top. }\end{array}$ \\
\hline
\end{tabular}


TABLE 5.-Descriptions of mirldle and lower Bajocinn fossil localities in southern Alaska-Continned

\begin{tabular}{|c|c|c|c|}
\hline $\begin{array}{l}\text { Locality } \\
\text { No. }\end{array}$ & $\begin{array}{l}\text { USGS Mesozoic } \\
\text { locality }\end{array}$ & $\begin{array}{l}\text { Collector's } \\
\text { field No. }\end{array}$ & Collector, year of collection, description of locality. and stratigraphic assignment \\
\hline 33 & 21257 & 48AI91 & $\begin{array}{l}\text { R. W. Imlay and D. J. Miller, 1948. North-central part of SW }{ }_{4} \text { sec. } 28 . \mathrm{T} .32 \mathrm{~S} . \text { R. } 44 \mathrm{~W} \text {. } \\
\text { Kialagvik Formation, from base of silty sandstone, overlying sandstone whose top is } 400 \mathrm{ft} \\
(122 \mathrm{~m}) \text { below top of formation. }\end{array}$ \\
\hline 33 & …................... & L1038 . & $\begin{array}{l}\text { Geologists of the Shell Oil Co. On the tributary entering Short Creek from the north in the } \\
\text { SW }{ }_{14} \text { sec. } 28 \text {, T. } 32 \mathrm{~S} \text {., R. } 44 \text { W. Kialagvik Formation. from lower third of } 490 \mathrm{ft}(150 \mathrm{~m}) \text { of } \\
\text { silty shale. }\end{array}$ \\
\hline 33 & $31976 \ldots \ldots . .$. & 80ACe199B & $\begin{array}{l}\text { Jim Case, } 1980 \text {. North-central part of } \mathrm{SW}^{1} \text { s sec. } 28, \text { T. } 32 \mathrm{~S} ., \text { R. } 44 \mathrm{~W} ., 1 \mathrm{mi}(0.6 \mathrm{~km}) \mathrm{N} .58^{\circ} \mathrm{W} . \\
\text { of Tri. Station Creek. Kialagvik Formation, sandstone and limestone beds. }\end{array}$ \\
\hline 34 & 21256 & 48AI90 & $\begin{array}{l}\text { R. W. Imlay. 1948. On ridge south of tributary entering Short Creek, } 4.6 \mathrm{mi} \mathrm{N} .75_{\frac{1}{1 / 2}}^{\circ} \text { W. of west } \\
\text { end of Hartman Island. } \mathrm{SE}^{1 / 4} \mathrm{SW}_{1 / 4}^{1 / 4} \text { sec. } 28 \text {. T. } 32 \mathrm{~S} \text {., R. } 44 \text { W. Kialagvik Formation, } 320 \mathrm{ft} \\
(98 \mathrm{~m}) \text { below top. }\end{array}$ \\
\hline 35 & 19786 & $44 \mathrm{AKMF} 56$ & $\begin{array}{l}\text { L. B. Kellum, } 1944 . \mathrm{NW}^{1} \mathrm{NE}_{4} \mathrm{~N}_{4} \mathrm{sec} .3 . \mathrm{T} .32 \mathrm{~S} . \text { R. } 44 \mathrm{~W} ., 5.75 \mathrm{mi}(9.2 \mathrm{~km}) \mathrm{N} .76^{\circ} \mathrm{W} \text {. of west } \\
\text { end of Hartman Island. In canyon of Short Creek, } 0.5 \mathrm{mi}(0.8 \mathrm{~km}) \text { above first rapids. } \\
\text { Kialagvik Formation, } 100 \mathrm{ft}(30 \mathrm{~m}) \text { below top in a shale bed interbedded with sandstone. }\end{array}$ \\
\hline 36 & $19755 \ldots \ldots$ & $44 \mathrm{AKMF} 21$ & $\begin{array}{l}\text { L. B. Kellum, 1944. North-central part of sec. } 33 \text {, T. } 32 \mathrm{~S} ., \mathrm{R} .44 \mathrm{~W} . \text {, about } 100 \mathrm{ft}(0.2 \mathrm{~km}) \text { north } \\
\text { of intersection of stream entering Short Creek from the north and } 0.75 \mathrm{mi} \text { downstream } \\
\text { from first falls. Kialagvik Formation, } 603 \mathrm{ft}(184 \mathrm{~m}) \text { below top in } 2 \mathrm{ft}(0.6 \mathrm{~m}) \text { of shabby } \\
\text { sandstone } 30 \mathrm{ft}(9 \mathrm{~m}) \text { below top of falls. }\end{array}$ \\
\hline 36 & 21254 & $48 \mathrm{AI} 109$ & $\begin{array}{l}\text { R. W. Imlay, } 1948 . \text { North-central part of sec. } 33, \mathrm{~T} .37 \mathrm{~S} ., \mathrm{R} .44 \mathrm{~W} \text {. Above the falts on a tribu- } \\
\text { tary entering Short Creek } 1 \mathrm{mi}(1.6 \mathrm{~km}) \text { northwest of the beach. Kialagvik Formation. } \\
\text { about } 600 \mathrm{ft}(183 \mathrm{~m}) \text { below top in gray calcareous sandstone. }\end{array}$ \\
\hline 36 & .. $31978 \ldots .$. & $80 \mathrm{ACe} 200$ & $\begin{array}{l}\text { Jim Case, 1980. North-central part of sec. } 33 . \text { T. } 32 \mathrm{~S} ., \text { R. } 44 \text { W.. } 0.67 \mathrm{mi}(1 \mathrm{~km}) \mathrm{N} .84^{\circ} \text { W. of } \\
\text { Tri. Station Creek. Kialagvik Formation. }\end{array}$ \\
\hline 36 & 31979 & $80 \mathrm{~A}$. & Jim Case. 1980 . Location is the same as \\
\hline 37 & 19748 & $44 \mathrm{AKmF} 13$ & $\begin{array}{l}\text { L. B. Kellum, } 1944 . \mathrm{SW}^{1} \mathrm{NE}^{1 / 4} \mathrm{sec} .33 . \mathrm{T} .32 \mathrm{~S} ., \mathrm{R} .44 \mathrm{~W} . . \text { on south side of Short Creek about } \\
1.5 \mathrm{mi}(2.4 \mathrm{~km}) \text { from its mouth and } 750 \mathrm{ft}(229 \mathrm{~m}) \text { below the first rapids. Kialagvik For- } \\
\text { mation. } 800 \mathrm{ft}(244 \mathrm{~m}) \text { below top, at top of a coarse conglomerate. }\end{array}$ \\
\hline $37 \quad \ldots \ldots . .$. & .. & A 454 & $\begin{array}{l}\text { Shell Oil Co., } 1953 \text {. On Short Creek probably at same location as USGS Mesozoic loc. } 19748 \\
\text { (see map by Westermann, 1964, text-fig. 2, opposite p. 332). Kialagvik Formation, about } \\
160 \mathrm{~m} \text { below top. }\end{array}$ \\
\hline $38 \ldots \ldots$. & $21245 \ldots \ldots . .$. & $48 \mathrm{AI} 86$ & $\begin{array}{l}\text { R. W. Imlay and D. J. Miller, 1948. South-central part of NE } \mathrm{N}^{1 / 4} \mathrm{sec} .33, \mathrm{~T} .32 \mathrm{~S} . \text { R. } 44 \mathrm{~W} . \text {, on } \\
\text { south side of Short Creek. Kialagvik Formation, about } 1.050 \mathrm{ft}(317 \mathrm{~m}) \text { below top, fossils } \\
\text { from a gray sandstone bed, dark-gray siltstone. }\end{array}$ \\
\hline 38 & 19747 & $44 \mathrm{AKmF} 12$ & $\begin{array}{l}\text { L. B. Kellum, 1944. South side of Short Creek at same location as USGS Mesozoic loc. } 21245 \text {. } \\
\text { Kialagvik Formation, } 317 \mathrm{~m} \text { below top. }\end{array}$ \\
\hline 38 & 21250 & $48 \mathrm{AI} 88$ & $\begin{array}{l}\text { R. W. Imlay and D. J. Miller, 1948. Short Creek at head of first falls near USGS Mesozoic loc. } \\
\text { 21245. Kialagvik Formation. } 600 \mathrm{ft}(183 \mathrm{~m}) \text { below top, gray sandstone at top of a sandstone } \\
\text { sequence. }\end{array}$ \\
\hline 39 & 21248 & 48AI108 & $\begin{array}{l}\text { R. W. Imlay and D. J. Miller, } 1949 \text {. Central part of NW'1/4 sec. } 34 \text {. T. } 32 \text { S., R. } 44 \text { W., on south } \\
\text { side of Short Creek about } 0.5 \text { mi }(0.8 \mathrm{~km}) \text { from beach. Kialagvik Formation, about } 1,700 \mathrm{ft} \\
(518 \mathrm{~m}) \text { below top, grav siltstone. }\end{array}$ \\
\hline 40 & 21247 & 48AI107 & $\begin{array}{l}\text { R. W. Imlay and D. J. Miller, } 1948 . \mathrm{SE} \text { corner of } \mathrm{NE}^{1 / 4} \mathrm{sec} .34, \mathrm{~T} .32 \mathrm{~S} . \mathrm{R} .44 \mathrm{~W} ., 0.2 \mathrm{mi}(0.3 \\
\mathrm{km}) \text { from beach. Kialagvik Formation, about } 2,000 \mathrm{ft}(610 \mathrm{~m}) \text { below top, dark-gray silt- } \\
\text { stone. }\end{array}$ \\
\hline $41 \ldots \ldots$ & $19776 \ldots \ldots . .$. & $44 \mathrm{AKmF} 46$ & $\begin{array}{l}\text { L. B. Kellum, 1944. } \mathrm{NW}_{4}^{1{ }_{4}} \mathrm{NE}^{1,4} \text { sec. } 3, \mathrm{~T} .33 \mathrm{~S} ., \mathrm{R} .45 \mathrm{~W} . \text {, on northeast side of Anderson Creek } \\
\text { at base of a bluff. Kialagvik Formation, about } 200 \mathrm{ft}(62 \mathrm{~m}) \text { below top, shaly sandstone. }\end{array}$ \\
\hline 42 & 11352 & 15 & $\begin{array}{l}\text { W. R. Smith, } 1922 \text {. North-central part of } \mathrm{SW}^{1}{ }_{4} \mathrm{sec} .2 \text {. T. } 32 \mathrm{~S} . \text {. R. } 45 \mathrm{~W} . \text {. on high knob on north } \\
\text { side of Anderson Creek, about } 1 \mathrm{mi}(1.6 \mathrm{~km}) \text { from Wide Bay. Kialagvik Formation. }\end{array}$ \\
\hline 42 & $19773 \ldots \ldots$ & $44 \mathrm{AKmF} 43$ & $\begin{array}{l}\text { L. B. Kellum, 1944. Same location as USGS Mesozoic loc. 11352. Kialagvik Formation, about } \\
220 \mathrm{ft}(67 \mathrm{~m}) \text { below top. }\end{array}$ \\
\hline 42 & $19775 \ldots \ldots$ & $44 \mathrm{AKmF} 45$ & $\begin{array}{l}\text { L. B. Kellum, 1944. Same location as USGS Mesozoic loc. 11352. Kialagvik Formation. about } \\
300 \mathrm{ft}(91 \mathrm{~m}) \text { below top, shaly sandstone near base of a cliff. }\end{array}$ \\
\hline 42 & 21258 & 48AI96 & $\begin{array}{l}\text { R. W. Imlay and D. J. Miller, 1948. Same location as USGS Mesozoic loc. 11352. Kialagvik } \\
\text { Formation, about } 225 \mathrm{ft}(69 \mathrm{~m}) \text { below top. }\end{array}$ \\
\hline 43 & 31987 & $8 \mathrm{ACe} 202 \mathrm{~A}$ & $\begin{array}{l}\text { Terry Poulton, 1980. South-central part of } \mathrm{NE}_{1 / 4}^{1} \mathrm{sec} .2 \text {, T. } 33 \mathrm{~S} ., \text { R. } 45 \mathrm{~W} ., 1.95 \mathrm{mi}(3.2 \mathrm{~km}) \mathrm{N} \text {. } \\
45^{\circ} \text { E. of Triangulation Station Spit in Ugashik B-2 quad. Kialagvik Formation. }\end{array}$ \\
\hline 43 & 10806 & $1-107$ & $\begin{array}{l}\text { S. R. Capps, 1921. Probably same location as USGS Mesozoic loc. } 31987 \text { and about } 1 \mathrm{mi} \text { (1.6 } \\
\mathrm{km} \text { ) north-northwest of mouth of "Anderson" Creek. Kialagvik Formation (partly float } \\
\text { specimens collected at base of bluff on west side of a spit). }\end{array}$ \\
\hline
\end{tabular}


TABLE 5.-Deseriptions of middle and lower Bajocian fossil localitit's in southern Alaska-Continued

\begin{tabular}{|c|c|c|c|}
\hline $\begin{array}{l}\text { Locality } \\
\text { No. }\end{array}$ & $\begin{array}{l}\text { USGS Mesozoic } \\
\text { locality }\end{array}$ & $\begin{array}{l}\text { Collector's } \\
\text { field No. }\end{array}$ & Collector, year of collection, description of locality, and stratigraphic assignment \\
\hline 44 & 21253 & $48 \mathrm{AI} 105$ & $\begin{array}{l}\text { R. W. Imlay and D. J. Miller, } 1948 \text {. Sea cliff in west-central part of NW1/4 sec. } 11, \mathrm{~T} .33 \mathrm{~S} . . \mathrm{R} . \\
45 \mathrm{~W} . \text { about } 1 \mathrm{mi}(1.7 \mathrm{~km}) \text { northeast of Triangulation Station Spit. Kialagvik Formation, } \\
\text { probably about } 500 \mathrm{ft}(152 \mathrm{~m}) \text { below top of formation. }\end{array}$ \\
\hline 45 & 31982 & $80 \mathrm{ACe} 202$ & $\begin{array}{l}\text { Jim Case, } 1980 . \mathrm{NW}^{1 / 4} \mathrm{SE}_{4} \text { sec. } 10, \text { T. } 33 \mathrm{~S} ., \text { R. } 45 \mathrm{~W} ., 0.57 \mathrm{mi}(0.9 \mathrm{~km}) \text { N. } 30^{\circ} \text { E. of Triangula- } \\
\text { tion Station Spit. Kialagvik Formation, calcareous sandstone. }\end{array}$ \\
\hline ....... & 31980 & $80 \mathrm{ACe} 201$ & $\begin{array}{l}\text { Jim Case, } 1980 . \text { On beach in NW1/4 sec. } 15 ., \text { T. } 33 \text { S., R. } 45 \text { W., } 0.18 \mathrm{mi}(0.3 \mathrm{~km}) \text { N. } 84 \text { W. of Tri- } \\
\text { angulation Station Spit in Ugashik B-2 quad. Kialagvik Formation, conglomerate. }\end{array}$ \\
\hline 47 & 10809 & $1-113$ & $\begin{array}{l}\text { S. R. Capps, } 1921 \text {. North-central part of sec. 17, T. } 33 \mathrm{~S} \text {., R. } 45 \mathrm{~W} \text {.. } 1.5 \mathrm{mi}(2.4 \mathrm{~km}) \text { from mouth } \\
\text { of creek that enters Wide Bay from the southwest. Kialagvik Formation, upper part. }\end{array}$ \\
\hline ........ & $31955 \ldots \ldots \ldots$ & $80 \mathrm{ACe} 163 \mathrm{~B}$ & $\begin{array}{l}\text { Jim Case, } 1980 \text {. NE corner of sec. } 16, \text { T. } 33 \text { S., R. } 45 \text { W., } 1.4 \mathrm{mi}(2.3 \mathrm{~km}) \mathrm{S} .77^{\circ} \text { W. of Triangula- } \\
\text { tion Station Spit in Ugashik B-2 quad. Kialagvik Formation, brownish mudstone. }\end{array}$ \\
\hline 49 & 31956 & $80 \mathrm{ACe} 164$ & $\begin{array}{l}\text { Jim Case, } 1980 \text {. East-central part of } \mathrm{NW}^{1 / 1} \text { sec. } 16, \mathrm{~T} .33 \mathrm{~S} ., \mathrm{R} .45 \mathrm{~W} ., 1.1 \mathrm{mi}(1.8 \mathrm{~km}) \mathrm{S} .73^{\circ} \mathrm{W} \text {. } \\
\text { of Triangulation Station Spit. Kialagvik Formation, float block of massive sandstone. }\end{array}$ \\
\hline 50 & 31951 & $80 \mathrm{ACe} 163$. & $\begin{array}{l}\text { Jim Case, } 1980 . \text { Near beach in } \mathrm{SE}^{1 / 4} \mathrm{NW}^{1 / 4} \text { sec. } 16, \mathrm{~T} .33 \mathrm{~S} . \text { R. R. } 45 \mathrm{~W} ., 1.3 \mathrm{mi}(2.1 \mathrm{~km}) \mathrm{S} .73^{\circ} \mathrm{W} . \\
\text { of Triangulation Station Spit. Kialagvik Formation, calcareous sandstone concretions. }\end{array}$ \\
\hline 50 & 31949 & $80 \mathrm{ACe} 162$ & Jim Case. 1980. Same data as for USGS Mesozoic loc. 31951. Kialagvik Formation, float. \\
\hline 51 & 31947 & $80 \mathrm{ACe} 161$ & $\begin{array}{l}\text { Jim Case, } 1980 . \mathrm{SE}^{1 / 4} \mathrm{NE}_{4}^{1} \text { sec. } 17 . \mathrm{T} .33 \mathrm{~S} . \text { R. } 45 \mathrm{~W} ., 1.5 \mathrm{mi}(2.5 \mathrm{~km}) \mathrm{S} .65^{\circ} \mathrm{W} \text {. of Triangulation } \\
\text { Station Spit. Kialagvik Formation, pebbly sandstone. }\end{array}$ \\
\hline 52 & 31957 & $80 \mathrm{ACe} 174$ & $\begin{array}{l}\text { Jim Case, } 1980 \text {. West-central part of NE } \mathrm{N}_{4}^{1} \mathrm{sec} .19 \text {. T. } 33 \mathrm{~S} . \text { R. } 45 \mathrm{~W} ., 2.5 \mathrm{mi}(4 \mathrm{~km}) \mathrm{N} .68^{\circ} \text { E. of } \\
\text { Triangulation Station Alai in Ugashik R-2 quad. Kialagvik Formation, massive sandstone. }\end{array}$ \\
\hline 52 & 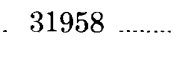 & $80 \mathrm{ACe} 174 \mathrm{~A}$ & $\begin{array}{l}\text { Jim Case, 1980. Same locality as USGS Mesozoic loc. 31957. Kialagvik Formation, massive } \\
\text { sandstone. }\end{array}$ \\
\hline 53 & 19926 & $45 \mathrm{AKmF} 116$ & $\begin{array}{l}\text { L. B. Kellum, 1945. Cliff east of Kialagvik Creek below a glacier. West-central part of NW1/4 } \\
\text { sec. 4, T. } 34 \text { S., R. } 45 \text { W. Kialagvik Formation. }\end{array}$ \\
\hline 54 & 19742 & $44 \mathrm{AKmF} 3$ & $\begin{array}{l}\text { L. B. Kellum, 1944. Southeast shore of Wide Bay in south-central part of sec. } 33 \text {. T. } 33 \text { S., R. } 34 \\
\text { W. Kialagvik Formation, float blocks of sandstone. }\end{array}$ \\
\hline 54 & $19796 \ldots \ldots$ & $44 \mathrm{AKmF} 66$ & $\begin{array}{l}\text { L. B. Kellum, 1944. Southeast shore of Wide Bay at same location as USGS Mesozoic loc. } \\
\text { 19742. Kialagvik Formation, float from a bluff. }\end{array}$ \\
\hline 55 & 11349 & F13. & $\begin{array}{l}\text { W. R. Smith, 1922. Near beach on south side of small creek in north-central part of SE } 1 / 4 \text { of sec. } \\
\text { 33. T. } 33 \text { S., R. } 45 \text { W. Kialagvik Formation. }\end{array}$ \\
\hline 55 & 12404 & & W. R. Smith, 1924. Same location as USG \\
\hline 55 & $19884 \ldots \ldots$. & $45 \mathrm{AKmF} 74$ & $\begin{array}{l}\text { L. B. Kellum, } 1945 \text {. Sea cliff } 0.25 \mathrm{mi}(0.4 \mathrm{~km}) \text { southeast from SV } \\
\text { location as USGS Mesozoic loc. } 11349 \text {. Kialagvik Formation } \\
\mathrm{m}) \text { below top of cliff. }\end{array}$ \\
\hline 56 & & L556 . & $\begin{array}{l}\text { Shell Oil Co. } 0.25 \mathrm{mi}(0.3 \mathrm{~km}) \text { southwest of L555 and } 15 \mathrm{~m} \text { lower stratigraphically. SW1/4 } \mathrm{NE}^{1 / 4} \\
\text { sec. } 34 . \text { T. } 33 \mathrm{~S} \text {., R. } 45 \mathrm{~W} \text {. }\end{array}$ \\
\hline 57 & & L555 & $\begin{array}{l}\text { Shell Oil Co. NE }{ }^{1 / 4} \text { sec. } 34, \text { T. } 33 \text { S., R. } 45 \text { W., } 0.25 \mathrm{mi}(0.3 \mathrm{~km}) \text { northeast of Shell loc. L556. } \\
\text { Kialagvik Formation. }\end{array}$ \\
\hline 58 & 19798 & $44 \mathrm{~A} \mathrm{KmF} 68$ & $\begin{array}{l}\text { L. B. Kellum, } 1944 \text {. On beach in northwest corner of sec. } 35, \text { T. } 33 \text { S., R. } 45 \text { W. Kialagvik For- } \\
\text { mation, float from sea cliffs. }\end{array}$ \\
\hline 59 & 19836 & $45 \mathrm{AKmF} 29$ & $\begin{array}{l}\text { L. B. Kellum. 1945. Spur west of most easterly of two large streams on southeast shore. South- } \\
\text { central part of NW'1 sec. } 35 \text {, T. } 33 \mathrm{~S} . \text {. R. } 45 \mathrm{~W} \text {. Elev. } 475 \mathrm{ft} \text {. Kialagvik Formation, } 192 \mathrm{ft} \\
(58 \mathrm{~m}) \text { below top of formation in shaly, crumbly sandstone. }\end{array}$ \\
\hline 59 & 19840 & $45 \mathrm{AKmF} 33$ & $\begin{array}{l}\text { L. B. Kellum, 1945. Same location as USGS Mesozoic loc. } 19836 \text {. Elev. } 636 \mathrm{ft}(194 \mathrm{~m}) \text {. Kialag- } \\
\text { vik Formation, } 130 \mathrm{ft}(40 \mathrm{~m}) \text { below top of formation. }\end{array}$ \\
\hline 59 & 19850 & $45 \mathrm{~A} \mathrm{KmF} 43$ & $\begin{array}{l}\text { L. B. Kellum, 1945. Same location as USGS Mesozoic loc. 19836. Elev. } 600 \mathrm{ft}(183 \mathrm{~m}) \text {. Kialag- } \\
\text { vik Formation. float collected in a gully. }\end{array}$ \\
\hline 60 & 19852 & $45 \mathrm{AKmF} 45$ & $\begin{array}{l}\text { L. B. Kellum, 1945. In east-central part of NW1/4 sec. } 35 \text {, T. } 33 \mathrm{~S} ., \text { R. } 45 \mathrm{~W} \text {. Elev. } 736 \mathrm{ft}(224 \mathrm{~m}) \text {. } \\
\text { Kialagvik Formation, talus. }\end{array}$ \\
\hline 61 & & $\mathrm{~L} 154$ & $\begin{array}{l}\text { Shell Oil Co. On shore in west-central part of } \mathrm{SE}^{1 / 4} \mathrm{sec} .26 . \mathrm{T} .33 \mathrm{~S} ., \mathrm{R} .45 \mathrm{~W} . \text {, about } 3 \mathrm{mi}(5 \mathrm{~km}) \\
\text { east of mouth of Kialagvik Creek, } 60 \mathrm{~m} \text { below top. }\end{array}$ \\
\hline 62 & $19811 \ldots \ldots$. & $45 \mathrm{AKmF} 4$ & $\begin{array}{l}\text { L. B. Kellum. 1945. NW }{ }^{1 / 4} \mathrm{SE}^{1 / 4} \text { sec. } 25 . \mathrm{T} .33 \mathrm{~S} ., \mathrm{R} .45 \mathrm{~W} . \text {.. about } 3,000 \mathrm{ft}(0.9 \mathrm{~km}) \text { east of mouth } \\
\text { of more easterly of two large creeks. Kialagvik Formation, } 45 \mathrm{ft}(13.7 \mathrm{~m}) \text { below top in a } \\
\text { shaly sandstone bed, at elev. of } 134 \mathrm{ft}(41 \mathrm{~m}) .\end{array}$ \\
\hline 63 & 31969 & $80 \mathrm{ACe} 177 \mathrm{~A}$ & $\begin{array}{l}\text { Jim Case, } 1980 . \mathrm{NE}^{1 / 4} \mathrm{sec} .25, \mathrm{~T} .33 \mathrm{~S} ., \mathrm{R} .45 \mathrm{~W} ., 3.25 \mathrm{mi}(5.2 \mathrm{~km}) \mathrm{S} .50^{\circ} \text { E. of Triangulation } \\
\text { Station Spit. Kialagvik Formation, mudstone about } 25 \mathrm{ft}(3.6 \mathrm{~m}) \text { below the cliff-forming } \\
\text { sandstone. }\end{array}$ \\
\hline 63 & 32287 & 81JCH11 & $\begin{array}{l}\text { J. H. Callomon, 1981. Same location as USGS Mesozoic loc. } 31969.1 .7 \mathrm{mi}(2.7 \mathrm{~km}) \mathrm{N} .15^{\circ} \mathrm{W} \text {. of } \\
\text { Triangulation Station Wide, } 60 \mathrm{~m} \text { above a sandstone cliff. Kialagvik Formation, } 198 \mathrm{ft}(60 \\
\text { m) above a sandstone cliff. }\end{array}$ \\
\hline
\end{tabular}




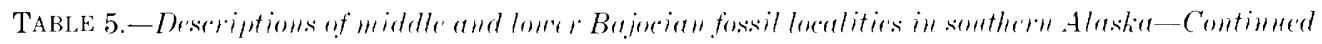

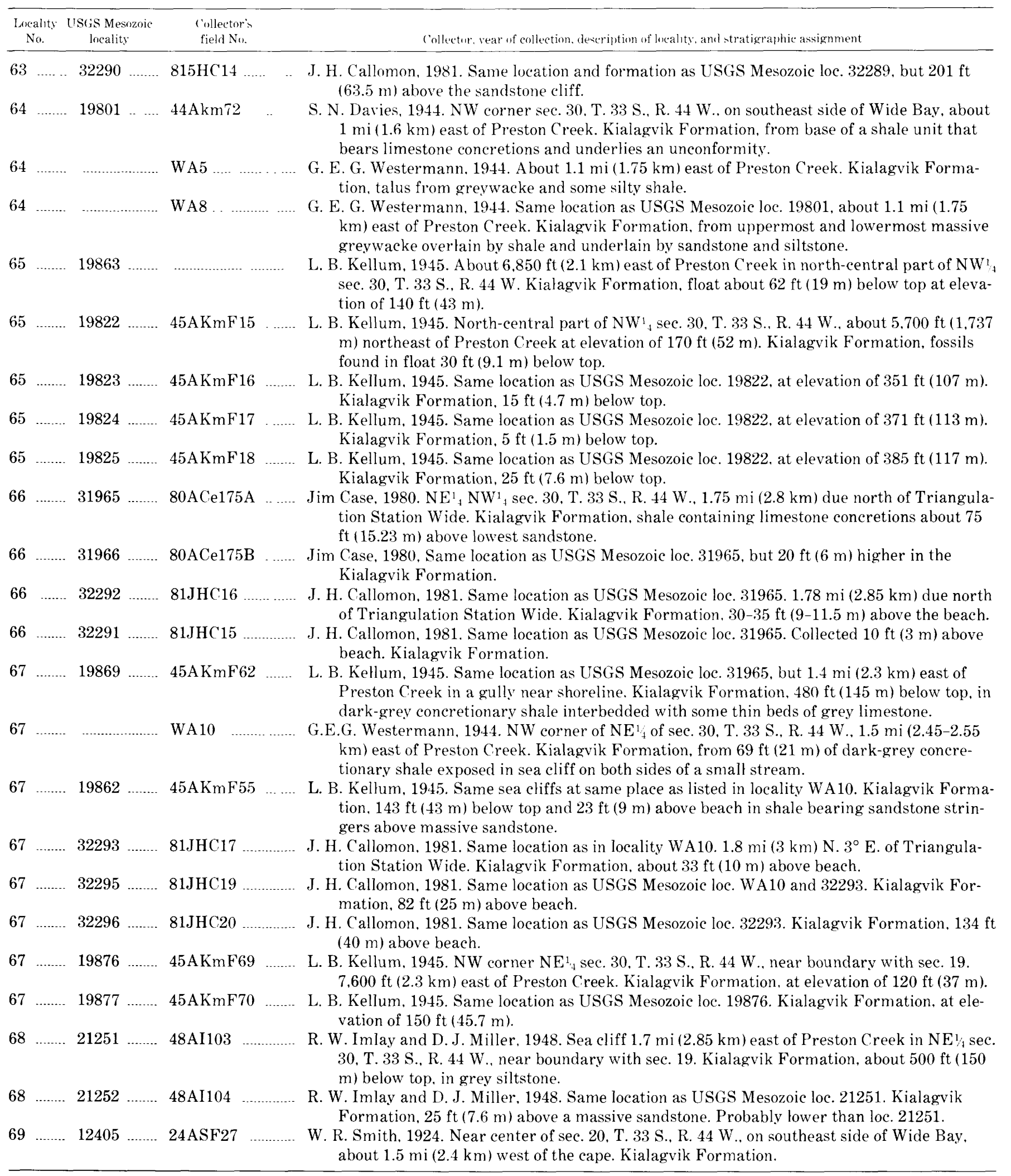


Toarcian for the lowest part of the Kialagvik Formation as exposed at Wide Bay. Nonetheless, it could represent float, as shown (1) by its association with three fragments of Erycitoides of late early Bajocian age, (2) by the occurrence of Erycitoides howelli (White) only $100 \mathrm{~m}$ farther south along the shore at USGS Mesozoic loc. 10807, and (3) by a field label written by S. R. Capps on Aug. 13, 1921, stating that the fossils collected at USGS Mesozoic loc. 10806 "[m]ay be partly erratic. Part came from talus at base of a bluff." It is possible, also, that the specimen of Hammatoceras was originally collected from upper Toarcian beds at Puale Bay, or that it was derived after early Bajocian time by erosion of Lower Jurassic beds that underlie Wide Bay and that to date have furnished the ammonite Waehneroceras of Hettangian age (Imlay, 1981, p. 12, pl. 2, figs. 14, 15). It is also possible that the specimen of Hammatoceras was collected along the south side of a fault that is uplifted on its south side.

Figured specimen.-USNM 335958.

Occurence.-Kialagvik Formation, at USGS Mesozoic loc. 10806 at west base of a spit about $3 \mathrm{mi}$ $(4.8 \mathrm{~km})$ from the southwest end of Wide Bay, Alaska Peninsula. Probably in SE1/4 SW1/4 sec. 10, T. 33 S., R. $45 \mathrm{~W}$., of the Ugashik (B-2) quad.

\section{Genus Erycitoides Westermann, 1964 \\ Erycitoides howelli (White)}

Plate 1, figure 7

One small, laterally crushed specimen closely resembles the coarsely ribbed inner whorls of certain lectotypes of $E$. howelli (White) (1889, p. 68, pl. 12, figs. 1, 2; pl. 14, figs. 2, 3) as figured by Westermann (1964, pl. 44, pl. 45, figs. 2a,b; pl. 47). The specimen has a fairly wide umbilicus. It bears strong, fairly widely spaced primary ribs that pass near the middle of the flanks into pairs of slightly weaker secondary ribs that weaken ventrally. A few fairly strong ribs arise high on the flanks between the rib pairs. All secondary ribs weaken near the midline of the venter, which bears a fairly sharp, low keel. All ribs incline gently forward on the flank and incline more strongly forward on the venter.

The species is possibly also represented at USGS Mesozoic loc. 22718 by one poorly preserved fragment of an outer whorl that bears ribbing similar to that on the adult lectotype (Westermann, 1964, pl. 44).

Occurrence.-Red Glacier Formation, float at USGS Mesozoic loc. 21234 and probably also at the same place as USGS Mesozoic loc. 21233 about $380-480 \mathrm{ft}$ (126-146 m) above Lower Jurassic volcanic rocks exposed southwest of Tuxedni Bay on the west side of Cook Inlet.
Subgenus Kialagvikes Westermann, 1964

Erycitoides (Kialagvikes) cf. E. kialagvikensis (White)

Plate 1 , figure 8

One laterally crushed specimen preserved on a slab of black shale represents parts of two whorls. The outermost whorl bears ribbing similar to that near the adapical end of the body chamber on finely ribbed specimens of Erycitoides (Kialagvikes) kialagvikensis (White) as figured by Westermann (1964, pl. 62, figs. $2 \mathrm{a}, \mathrm{b}$, and 3 ; pl. 63 , figs. 1a,b). Its primary ribs incline forward on the lower parts of the flanks and are of variable strength. Its strongest ribs terminate in weak, radially elongate tubercles near the middle of the flanks. Its secondary ribs are uniform in strength, curve backward on the upper part of the flanks, and then curve slightly forward on the margins of the venter. On the inner whorl the primary ribs appear to be weak and nearly uniform in strength.

Figured specimen.-USN M 335960.

Occurrence.-Red Glacier Formation, 2,200-2,300 ft above base, at USGS Mesozoic loc. $21244 \mathrm{~F}$ in Iniskin Bay Assoc. well 1 at a depth of 6,339-6,359 $\mathrm{ft}$ in $\mathrm{SE}^{1 / 4}$ sec. 8, T. 5 S., R. 23 W., near Fitz Creek in the Iniskin Peninsula.

\author{
Family Sonniniidae Buckman, 1892 \\ Genus Sonninia Bayle, 1879 \\ Sonninia tuxedniensis Imlay \\ Plate 2, figure 1
}

Sonninia tuxedniensis Imlay, n. sp., 1964, U.S. Geol. Survey Prof. Paper 418-B, p. B32, pl. 2, figs. 5-10.

This species is represented to date in the Kialagvik Formation by one small septate specimen that in shape and ornamentation is identical with the inner whorls of the holotype (Imlay, 1964, pl. 2, fig. 10). The specimen, at a diameter of $54 \mathrm{~mm}$, has a whorl height of $20 \mathrm{~mm}$, a whorl thickness of $16 \mathrm{~mm}$, and an umbilical width of $20 \mathrm{~mm}$. The whorls bear prominent ribs that trend radially, or slightly adorally on flanks, become less prominent adorally, and nearly fade out adorally on the upper third of the outermost preserved whorl.

Sonninia tuxedniensis in the Wide Bay area has not to date been found with other genera and therefore cannot be dated precisely. By contrast, in the Cook Inlet area of southern Alaska it occurs with Normannites, Teloceras, Chondroceras, and Zemistephanus (USGS Mesozoic locs. 2999, 3000, and 21266), which association is good evidence for correlation with the zone of Stephanoceras humphriesianum of Europe.

Hypotype.-USNM 335970.

Occurrence.-Kialagvik Formation at USGS Mesozoic loc. 10809 in the north-central part of sec. 17, T. 33 
N., R. 45 W., at the southwest side of Wide Bay in the Alaska Peninsula.

\section{Genus Fontannesia Buckman, 1902 \\ Fontannesia cf. F. carinata Buckman \\ Plate 2, figure 9}

cf. Fontannesia carinata Buckman, 1905. Palaeontographical Soc. of London, p. CLXXXIX (p. 189): 1892, pl. 47, figs. 13, 14.

Fontannesia cf. F. carinata Buckman. Imlay, 1973. U.S. Geol. Survey Prof. Paper 956, p. 58, pl. 5, figs. 4-13.

One small ammonite from Puale Bay is characterized by fairly evolute coiling, a keeled venter, and fairly broad, flexuous ribs that are faint on the lowest part of the flanks but become much stronger and broader ventrally and fade out rather abruptly before reaching the keel. This ammonite shows considerable resemblance to small specimens of Fontannesia from eastern Oregon that were figured by Imlay (1973, p. 5, figs. 4 and 10). Its ribs do not curve backward nearly as much as in specimens of Pelekodites figured by Westermann (1969, p. 126, pl. 32, figs. 1 and 2$)$.

Figured specimen.-USNM 335997.

Occurrences.-Kialagvik Formation, at USGS Mesozoic loc. 21235 on the northeast side of Puale Bay (see figs. 6 and 10$)$ about $200 \mathrm{ft}(61 \mathrm{~m})$ below massive conglomeratic sandstone.

\section{Family Oppeliidae Bonavelli, 1894 \\ Genus Bradfordia Buckman, 1910 \\ Bradfordia costidensa Imlay \\ Plate 1, figures 9-12}

Bradfordia costidensa Imlay, n. sp. 1964, U.S. Geol. Survey Prof. Paper 418-B, p. B39, pl. 8, figs. 1-10.

This species is fairly common in the Wide Bay area in association with the ammonites Otoites, Stephanoceras, Parabigotites, Eudmetoceras (Euaptetoceras), and Sonninia (Papilliceras). It is represented in the Puale Bay area by one small, immature specimen that is associated with Fontannesia.

This species is characterized by an elliptical whorl section, gently convex flanks, a narrowly rounded venter, a fairly narrow umbilicus, a vertical umbilical wall, a sharp umbilical edge, and fine to fairly fine falcoid ribs that are strongest on the upper part of the flanks and become much weaker adorally on the body chamber. Small, immature forms of Bradfordia cost idensa Imlay show more resemblance to Lissoceras bakeri Imlay (1962, pl. 1, figs. 1-6, 9-12), but differ by having much stronger ribbing at a comparable size and by its umbilical wall rounding more abruptly into its flanks.

Types.-Hypotype USNM 335961 and 335962.
Occurrences.-Kialagvik Formation in the Wide Bay area at USGS Mesozoic locs. 19742, 19786, 19798, $19823,19850,19852,19884,21256,21257$, and many other localities (see table 4). It occurs in the Kialagvik Formation in the Puale Bay area at USGS Mesozoic loc. 21235.

\section{Family Otoitidae Mascke, 1907}

Docidoceras (Pseudocidoceras) widebayense Westermann Plate l, figs. 20, 24

Docidoceras (Psendocidoceras) widebayense Westermann, 1969, Bulls. American Paleontology, v. 57, no. 255, p. 137-146. pls. 34-37.

This species is characterized (1) by a depressed whorl section, (2) by its adult body chamber becoming more evolute adorally, (3) by its ribs changing adorally from fairly weak and closely spaced on the septate whorls to very strong and widely spaced on the body chamber, (4) by its primary ribs on the outermost whorl inclining forward on the lower third of the flanks where they terminate in small tubercles, (5) by the tubercles passing into pairs of slightly weaker secondary ribs, and (6) by the secondary ribs curving strongly adorally on the venter of the body whorl.

This species has been found at many places on the southeast side of Wide Bay and at one place on the northwest side. Associated taxa include Sonninia (Alaskina) alaskensis Westermann, S. (Euhoploceras) bifurcata Westermann, Praeoppelia oppeliiform is (Westermann), Pseudolioceras maclintoch i fastigatum Westermann, and Eudmetoceras (Euaptetoceras) klimakom phalum discoidale Westermann. These in association show that the beds containing $D$. (P.) widebayense Westermann correlate with the European zone of Sonninia sowerbyi.

Hypotype.-USNM 335965.

Occurrences.-Kialagvik Formation at USGS Mesozoic locs. 12405, 19801, 19862, 19869, 21251, 21252 , 31958,32293 , and 32296 .

\section{Otoites cf. O. contractus (J. de C. Sowerby)}

Plate 1, figures 13-17

This genus is represented on the Alaska Peninsula by four fragments, of which two fit together as part of the body whorl and are somewhat crushed laterally. The other two specimens are much smaller, and bear very fine, closely spaced secondary ribs that outnumber the slightly stronger primary ribs about 4 to 1. Those secondary ribs greatly resemble the secondary ribs on the inner whorls of the holotype of Otoites contractus (J. de C. Sowerby) from England (Buckman, 1920, pl. 158) and of specimens from eastern Oregon (Imlay, 1973, pl. 39, figs. 1 and 7) and from Germany (Westermann, 1954, p. 92, pl. 1, figs. 4, 5). 
The ribs on the body whorl become much coarser and sparser adorally. They arise by threes from the primary ribs at the adapical end of the body chamber and by twos at the adoral end of that chamber. The secondary ribs arise from weak tubercles on the small septate whorls and from prominent tubercles on the body chamber. The coarseness of ribbing on the body whorl is likewise comparable to that on the specimens illustrated by Buckman and Westermann as just listed.

Figured specimens.-USNM 335963 and 335964.

Occurrence.-Upper part of the Kialagvik Formation at USGS Mesozoic loc. 21257 in the Wide Bay area on the Alaska Peninsula.

\section{Family Sphaeroceratidae Buckman, 1920 \\ Genus Chondroceras Mascke, 1907 \\ Chondroceras cf. C. colnetti (McLearn) \\ Plate 2, figures 10, 13}

Two laterally crushed adult specimens resemble Chrondroceras colnetti (McLearn) (1929, p. 15, pl. 13, figs. 4,5 ) by having high, sharp ribs that do not weaken adorally. Most of their primary ribs bifurcate, or trifurcate a little below the middle of the flanks. Most forked ribs are separated by a single rib that arises freely near the middle of the flanks. The ribbing differs from that on C. marchandi McLearn (1929, p. 14 , p. 12, figs. 4,5 ) by being much sharper and higher.

Figured specimens.-USNM 335998 and 335999.

Occurrence.-Nizina Mountain Formation. Float at USGS Mesozoic loc. 28682 in the Wrangell Mountains.

\footnotetext{
Family Stephanoceratidae Neumayr, 1875

Genus Normannites Munier-Chalmas, 1892

Subgenus Itinsaites McLearn, 1927

Normannites (Itinsaites?) variabilis Imlay Plate 2, figures 6-8
}

Normannites (Itinsaites?) variabilis Imlay, 1964, U.S. Geol. Survey Prof. Paper 418-B, p. B44, pl. 13, figs. 9, 12-16; pl. 14, figs. 12, 14.

Six specimens from the Wrangell Mountains are assigned to this species mainly because their ribbing changes from fine and dense on their septate whorls to fairly coarse and sparse on their body chamber. This is shown well on one lappeted adult (pl. 2, fig. 6), which greatly resembles certain paratypes (Imlay, 1964, pl. 13, fig. 13 and pl. 14, fig. 12). Because of lateral crushing the tubercles appear to be lower on the flanks of the specimens from the Wrangell Mountains than on the type specimens from north of Cook Inlet.

Hypotypes.-USNM 335973-335975.

Occurrence.-Nizina Mountain Formation at USGS Mesozoic loc. 28682 in the Wrangell Mountains.
Genus Stephanoceras Wadgen, I869

Subgenus Skirroceras Mascke, 1907

Stephanoceras (Skirroceras) cf. S. (S.) leptogyrale (Buckman)

Plate 2, figures 2-5

Stephanoceras (Skirroceras) cf. S. (S.) leptogyrale(Buckman). Imlay, 1973 , p. 88 , pl. 46 , fig. 15 .

This species is represented by two internal molds which show the characteristics of the inner whorls very well. Those whorls bear ribs nearly as fine as those in S. (S.) leptogyrale (Buckman) (1924, pl. 576) from England. The outermost preserved whorl bears somewhat coarser and more widely spaced ribs than on $S$. (S.) leptogyrale.

Figured specimen.-USNM 335971 and 335972.

Occurrences.-Kialagvik Formation at USGS Mesozoic loc. 19823 and 21257 , which are respectively in the NW cor. sec. 30, T. 33 S., R. 44 W., and in the $\mathrm{NE}^{1 / 4} \mathrm{SW}^{1 / 4}$ sec. 28, T. 32 S., R. 44 W., near Wide Bay on the Alaska Peninsula.

Genus Teloceras Mascke, 1907

Teloceras cf. T. blagdeni (Sowerby)

Plate 2, figures 12, 14

This species is represented by two crushed and distorted molds of which both exhibit fairly evolute coiling, coarse, widely spaced primary ribs, somewhat weaker secondary ribs, and prominent lateral tubercles. One of the specimens is an internal mold, which shows parts of three whorls of which the inner two are septate. The other specimen is an external mold, which shows parts of two whorls that closely resemble the outer two whorls shown on the internal mold. Presumably, the outermost whorl on each specimen represents part of the body chamber. On the outermost septate whorl of the internal mold the secondary ribs arise in bundles of three from four successive lateral tubercles. In addition, one secondary rib arises freely between the branched ribs along the zone of furcation. All these ribs appear to incline slightly forward.

Adorally on the outermost whorl of the external mold the ribs and tubercles become considerably stronger and more widely spaced, but the secondary ribs remain relatively much weaker than the primary ribs. The secondary ribs outnumber the primary ribs about three to one and arise mostly from the tubercles, but a few arise freely between the tubercles. All secondary ribs incline forward on the upper parts of the flanks. Similar secondary ribs are apparent on the fragmentary outermost whorl of the internal mold.

These specimens of Teloceras have appreciably stronger ribs and tubercles than occur on $T$. itinsae McLearn at comparable sizes (Imlay, 1964, pl. 23, figs. 9,10 , pl. 24, figs. 1-5, 7). In this respect, they show 
more resemblance to T. blagdeni (Sowerby) (Weisert, 1932, p. 168, pl. 18, fig. 2; Arkell, 1933, pl. 34, fig. 5), which in Europe characterizes the upper part of the zone of Stephanoceras humphriesiamum (Weisert, 1932 . p. 185), but has been recorded as high as the middle of the upper Bajocian (Arkell, 1956, p. 99, 278, 483).

Figured specimens.-USNM 336001 and 336000.

Occurrence.-Nizina Mountain Formation at USGS Mesozoic loc. 28682 in the Wrangell Mountains.

\section{REFERENCES CITED}

Arkell, W. J., 1933. The Jurassic system in Great Britain: Oxford, Clarendon Press, 681 p., 41 pls.

- 1956 , Jurassic geology of the world: London, Oliver \& Boyd, 806 p., 46 pls., 102 figs.

Arkell, W. J., Kummel, Bernhard, and Wright. C. W., 1957, Mesozoic Ammonoidea, in Moore, R. C., ed.. Treatise on invertebrate paleontology, part L, Mollusca 4, Cephalopoda, Ammonoidea: New York and Lawrence, Kans., Geol. Soc. America and Univ. Kansas Press, p. L80-L437.

Buckman. S. S., 1909-1930. Type ammonites: London, privately published, v. 1-7 (see v. 3, pl. 158, 1920).

Capps, S. R., 1922. The Cold Bay district, Alaska: U.S. Geol. Survey Bull. 739-C, p. 77-116, pl. 2, figs. 5, 6.

Detterman, R. L., 1963, Revised stratigraphic nomenclature and age of the Tuxedni Group in the Cook Inlet region, Alaska: U.S. Geol. Survey Prof. Paper 475-C, p. C30-C34.

Detterman, R. L., and Hartsock, J. K., 1966, Geology of the IniskinTuxedni region. Alaska: U.S. Geol. Survey Prof. Paper 512, 78 p., 6 pls., 7 figs.

Grantz, Arthur, 1965, Geologic maps and cross sections of the Nelchina area, south-central Alaska: U.S. Geol. Survey open-file rept., 4 sheets, scale 1:63,360.

Imlay, R. W., 1952, Correlation of the Jurassic formations of North America, exclusive of Canada; Geol. Soc. America Bull., v. 63 , no. 9 , p. 953-992, 2 correlation charts.

- - 1962, Late Bajocian ammonites from the Cook Inlet region, Alaska: U.S. Geol. Survey Prof. Paper 418-A. p. A1-A15, pls. $1-5.4$ figs.

- - 1964, Middle Jurassic (Bajocian) ammonites from the Cook Inlet region, Alaska: U.S. Geol. Survey Prof. Paper 418-B. p. 1-61, pls. 1-29, 5 figs.

_- 1973, Middle Jurassic (Bajocian) ammonites from eastern Oregon: U.S. Geol. Survey Prof. Paper 756, 100 p., 48 pls., 8 figs.
-_-1980, Middle Jurassic (Bathonian) ammonites from southern Alaska: U.S. Geol. Survey Prof. Paper 1091, p. 1-42, 12 płs., 11 figs.

- - 1981, Early Jurassic ammonites from Alaska: U.S. Geol. Survey Prof. Paper 1148, 49 p., 12 pls., 14 figs.

- - 1982, Late Bajocian ammonites from southern Alaska: U.S. Geol. Survey Prof. Paper 1189, 19 p., 7 pls., 7 figs.

Imlay, R. W., and Detterman, R. L., 1973, Jurassic paleobiogeography of Alaska: U.S. Geol. Survey Prof. Paper 801, 34 p., 15 figs.

- - - 1977, Some Lower and Middle Jurassic beds in Puale BayAlinchak Bay area, Alaska Peninsula: Am. Assoc. Petroleum Geologists Bull., v. 61. p. 607-611. 2 figs.

Karlstrom. T. N. V., 1964, Quaternary geology of the Kenai Lowland and glacial history of Cook Inlet region, Alaska: U.S. Geol. Survey Prof. Paper 443, 69 p.. 7 pls., 14 figs.

Kellum. L. B., Davies, J. N., and Swinney, C. M., 1945, Geology and oil possibilities of the southwestern part of the Wide Bay anticline, Alaska: U.S. Geol. Survey Prelim. Rept., 17 p., illus., incl. geol. map.

Martin, D. C., 1926, The Mesozoic stratigraphy of Alaska: U.S. Geol. Survey Bull. 776, $493 \mathrm{p}$.

MacKevett, E. M., Jr., 1969, Three newly named Jurassic formations in the McCarthy $\mathrm{C}-5$ quadrangle, Alaska: U.S. Geol. Survey Bull. 1274-A, p. A35-A49, figs. 3-8.

- - 1971. Stratigraphy and general geology of the McCarthy C-5 quadrangle, Alaska: U.S. Geol. Survey Bull. 1323, 35 p.

McLearn, F. H., 1929, Contributions to the stratigraphy and paleontology of Skidgate Inlet, Queen Charlotte Islands, British Columbia: Canada Nat. Mus. Bull. 54, Geol. Ser., no. 49, p. 1-27. 16 pls.

Smith, W. R., 1926, Geology and oil developments of the Cold Bay district: U.S. Geol. Survey Bull. 783, p. 63-88.

Smith, W. R., and Baker, A. A., 1924, The Cold Bay-Chignik district, Alaska: U.S. Geol. Survey Bull. 755, p. 151-218.

Weisert, Kurt, 1932, Stephanoceras im Schwabischen Braunen Jura Delta: Palaeontographica, v. 76, p. 121-191, pls. 15-19.

Westermann, G. E. G., 1954, Monographie der Otoitidae (Ammonoidea): Geol. Jahrb. Beihefte, no. 15, 364 p., 33 pls.

- 1964 , The ammonite fauna of the Kialagvik Formation at Wide Bay, Alaska Peninsula, part 1, Lower Bajocian (Aalenian): Bulls. Am. Paleontology, v. 47, p. 329-503, pls. 44-76, 37 figs. 1969. The ammonite fauna of the Kialagvik Formation at Wide Bay, Alaska Peninsula, Part 2. Sonninia sonerbyi zone (Bajocian): Bulls. Am. Paleontology, v. 57, no. 255, 226 p., pls. $1-47,56$ figs.

White. C. A., 1889, On invertebrate fossils from the Pacific coast: U.S. Geol. Survey Bull. 51, 102 p., 14 pls. 


\section{PLATES 1 AND 2}

Contact photographs of the plates in this report are available, at cost, from U.S. Geological

Survey Library, Federal Center. Denver, Colorado 80225 


\section{PLATE 1}

[Figures natural size unless otherwise indicated]

Figures 1-4. Asthenoceras cf. A. delicatum Imlay (p. 25).

1, 2. Ventral and lateral views of specimen, USNM 335956 from USGS Mesozoic loc. 19862.

3, 4. Ventral and lateral views of specimen, USNM 335957 from USGS Mesozoic loc. 19862.

5, 6. Hammatoceras sp. (p. 27). Ventral and lateral views of specimen, USNM 335958 from USGS Mesozoic loc. 10806.

7. Erycitoides howelli (White) (p. 35). Lateral view of hypotype USNM 335959 from USGS Mesozoic loc. 21234.

8. Erycitoides (Kialaguikes) ef E. (K.) kialagvikensis (White) (p. 35). Lateral view, USNM 335960 from USGS Mesozoic loc. $21244 F$.

9-12. Bradfordia costidensa Imlay (p. 36).

9, 10. Lateral and ventral views of hypotype, USNM 335961 from USGS Mesozoic loc. 19742.

11, 12. Lateral and ventral views $(\times 2)$ of hypotype, USNM 335962 from USGS Mesozoic loc. 21235.

13-17. Otoites cf. O. contractus (J. de C. Sowerby) (p. 36).

13-15. Lateral and ventral views of adoral end of the body whorl. The fragment shown in figure 15 fits only the adapical end of the specimen shown in fig. 13, USNM 335963 from USGS Mesozoic loc. 21257.

16, 17. Lateral and ventral views $(\times 2)$ of inner whorl, USNM 335964 from USGS Mesozoic loc. 21257.

18, 19. Tmetoceras scissum (Benecke) (p. 27).

18. Lateral view of hypotype, USNM 335965 from USGS Mesozoic loc. 21233.

19. Lateral view of hypotype, USNM 335966 from USGS Mesozoic loc. 21234.

20, 24. Docidoceras (Pseudocidoceras) widebayense Westermann (p. 36).

Lateral and ventral views of hypotype, USNM 335967 from USGS Mesozoic loc. 19862.

21-23. Tmetoceras kirki flexicostatum Westermann (p. 27).

21. Lateral view of hypotype, USNM 335968 from USGS Mesozoic loc. 21254.

22, 23. Ventral and lateral view of part of an outer whorl of hypotype USNM 335969 from USGS Mesozoic loc. 21254. 

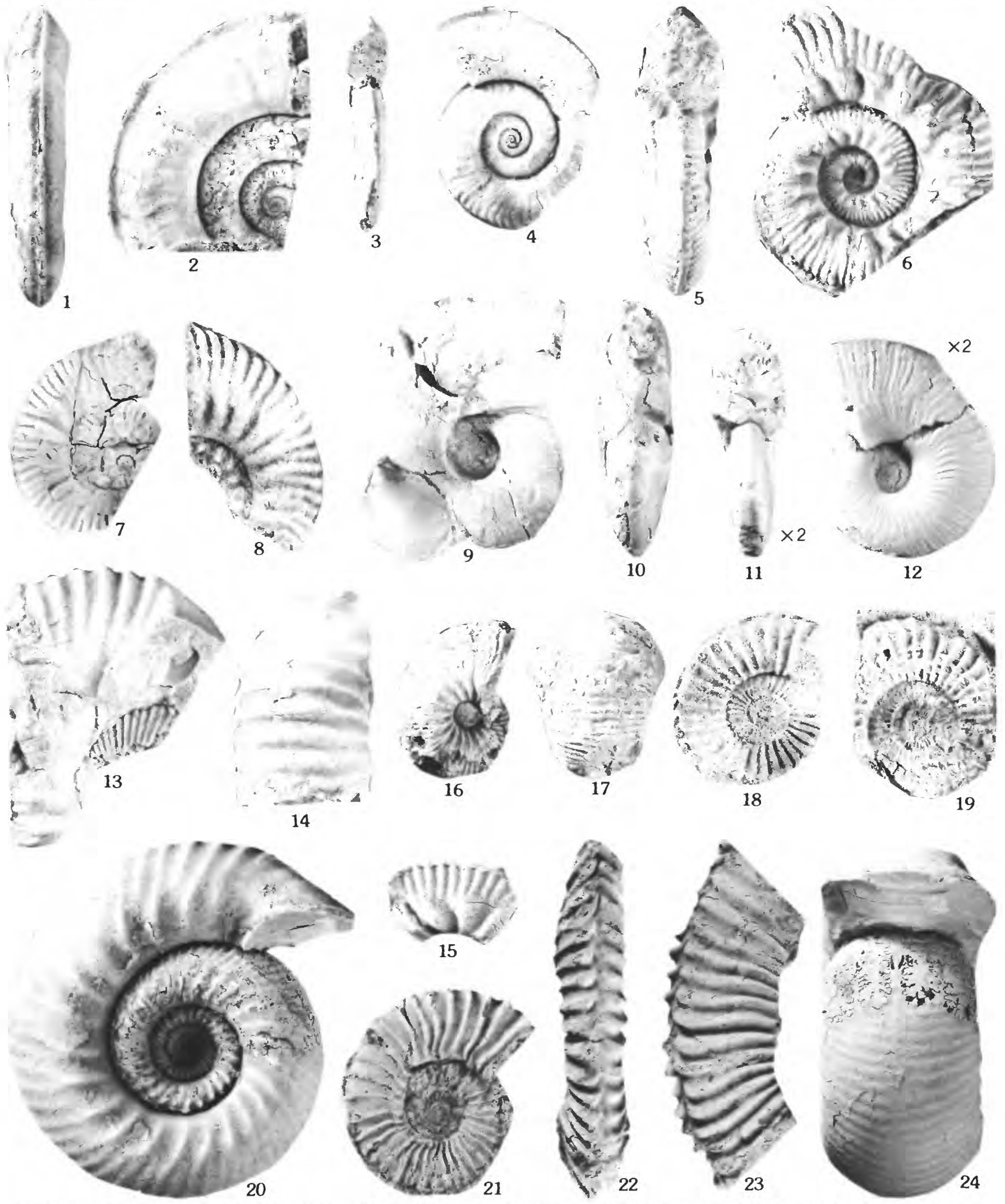

ASTHENOCERAS, TMETOCERAS, HAMMATOCERAS, ERYCITOIDES, E. (KIALAGVIKES), BRADFORDIA, AND OTOITES 


\section{PLATE 2}

[Figures natural size unless otherwise indicated]

Figure 1. Sonninia tuxedniensis Imlay (p. 35).

Hypotype, USNM 335970 from USGS Mesozoic loc. 10809. (p. 35).

2-5. Stephanoceras (Skirroceras) cf. S. ( S.) leptogyrale Buckman (p. 37).

2-4. Lateral and ventral views of specimen, USNM 335971 from USGS Mesozoic loc. 19823.

5. Lateral view of inner whorls of specimen, USNM 335972 from USGS Mesozoic loc. 21257.

6-8. Normannites (Itinsaites?) variabilis Imlay (p. 37).

6. Hypotype of adult body chamber, USNM 335973 from USGS Mesozoic loc. 28682.

7. Hypotypes of adapical end of body whorl, USNM 335974 from USGS Mesozoic loc. 28682.

8. Hypotype of part of an outer whorl, USNM 335975 from USGS Mesozoic loc. 28682.

9. Fontannesia cf. E. carinata Buckman (p. 36).

Lateral view $(\times 2)$ of specimen, USNM 335997 from USGS Mesozoic loc. 21235.

10, 13. Chondroceras cf. C. colnetti (McLearn) (p. 37).

10. Lateral view of rubber cast of external mold of body whorl, USNM 335998 from USGS Mesozoic loc. 28682.

13. Lateral view of body whorl, USNM 335999 from USGS Mesozoic loc. 28682.

11. Pseudolioceras cf. $P$. whiteavesi (White) (p. 25).

Laterally crushed specimen, USNM 336000 from USGS Mesozoic loc. 29341.

12, 14. Teloceras cf. T. blagdeni (Sowerby) (p. 37).

12. Internal mold of specimen, USNM 336001 from USGS Mesozoic loc. 28682.

14. Rubber cast of external mold of specimen USNM 356002 from USGS Mesozoic loc. 28682. 

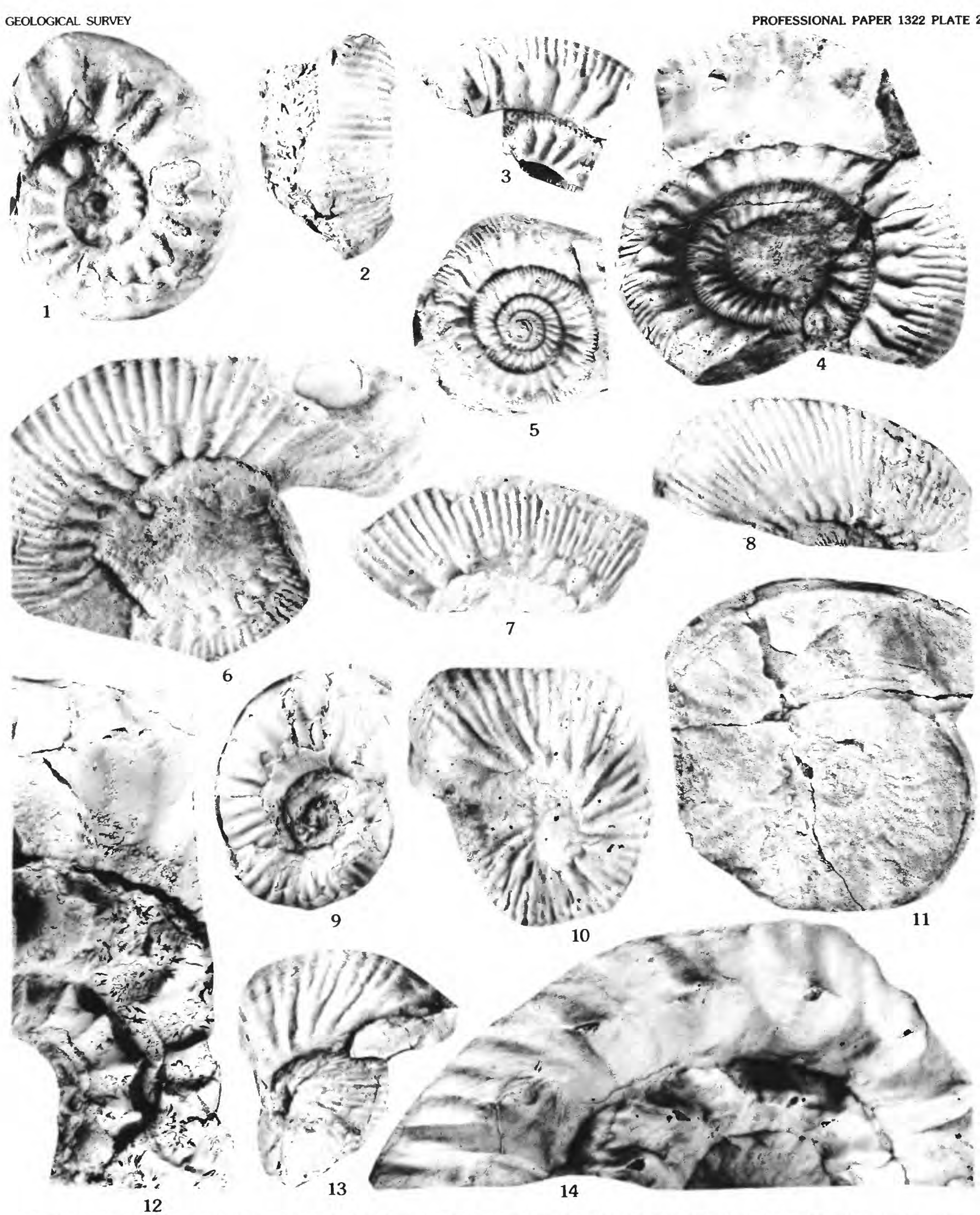

PSEUDOLIOCERAS, SONNINIA, FONTANNESIA, CHONDROCERAS, NORMANNITES, STEPHANOCERAS (SKIRROCERAS), AND TELOCERAS 